BUDAPESTI CORVINUS EGYETEM

TÁJÉPÍTÉSZETI ÉS TÁJÖKOLÓGIAI

DOKTORI ISKOLA

BÁRCZINÉ KAPOVITS JUDIT

\title{
A MAGYARORSZÁGI ZÖLDÚT-TERVEZÉS TÁJÉPÍTÉSZETI METODIKÁJÁNAK MEGALAPOZÁSA
}

DOKTORI ÉRTEKEZÉS

BUDAPEST, 2014 


\title{
A doktori iskola
}

megnevezése: Budapesti Corvinus Egyetem

Tájépítészeti és Tájökológiai Doktori Iskola

tudományága: Agrármüszaki

vezetője: $\quad$ Csemez Attila, DSc

egyetemi tanár

Budapesti Corvinus Egyetem

Tájtervezési és Területfejlesztési Tanszék

Témavezető: $\quad$ Csemez Attila, DSc

egyetemi tanár

Budapesti Corvinus Egyetem

Tájtervezési és Területfejlesztési Tanszék

Társ-témavezető: Sallay Ágnes, PhD

egyetemi docens

Budapesti Corvinus Egyetem

Tájtervezési és Területfejlesztési Tanszék

\begin{abstract}
A jelölt a Budapesti Corvinus Egyetem Doktori Szabályzatában elöírt valamennyi feltételnek eleget tett, az értekezés mühelyvitájában elhangzott észrevételeket és javaslatokat az értekezés átdolgozásakor figyelembe vette, ezért az értekezés védési eljárásra bocsátható.
\end{abstract}

Az iskolavezető jóváhagyása

A témavezető jóváhagyása 
A Budapesti Corvinus Egyetem Élettudományi Területi Doktori Tanács 2014. december 2-i ÉTDT-382/2014. számú határozatában a nyilvános vita lefolytatására az alábbi Bíráló Bizottságot jelölte ki:

BÍRÁLÓ BIZOTTSÁG:

\author{
Elnöke \\ M. Szilágyi Kinga, CsC \\ Tagjai \\ Konkoly-Gyúró Éva, CsC \\ Illyés Zsuzsanna, PhD \\ Kollányi László, PhD \\ Gergely Erzsébet, PhD \\ Opponensek \\ Gerzánics Annamária, CsC \\ Dömötör Tamás, PhD
}

Titkár

Filepné Kovács Krisztina, PhD 


\section{TARTALOMJEGYZÉK}

BEVEZETÉS

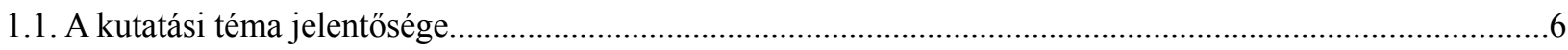

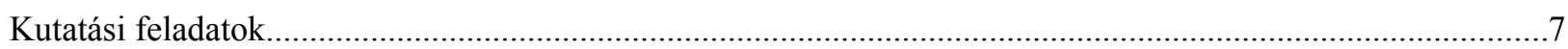

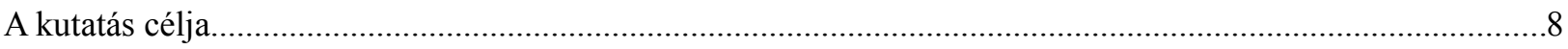

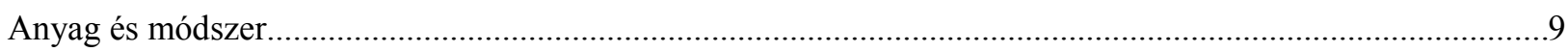

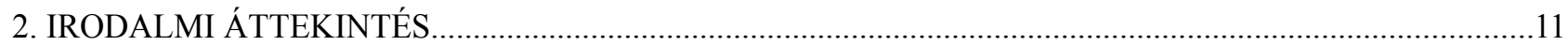

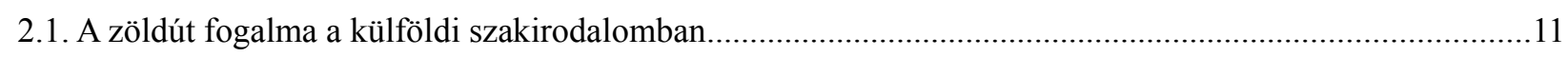

2.2. A zöldút fogalom megjelenése Magyarországon...................................................................................12

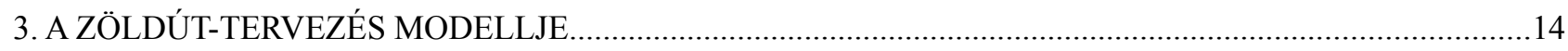

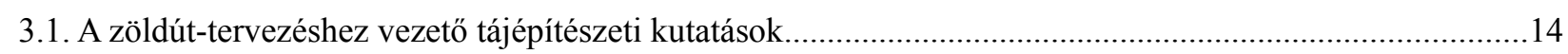

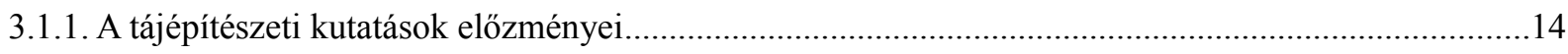

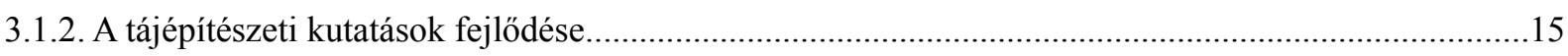

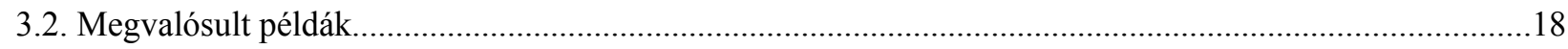

3.2.1. Boston zöldút-hálózatának fejlődése Olmsted tervétől napjainkig.....................................................18

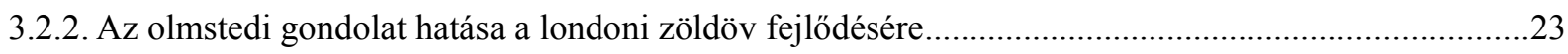

3.2.3. Az ottawai zöldöv kijelölésének hatása a kanadai zöldutak létesítésére.............................................25

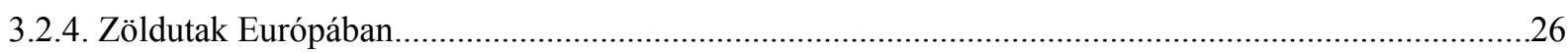

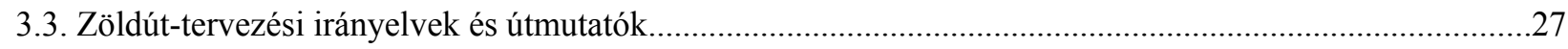

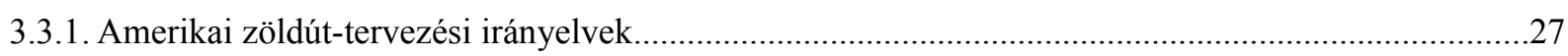

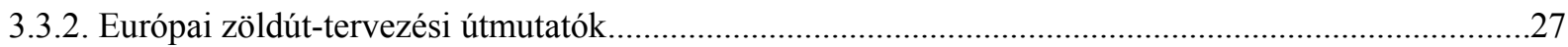

3.4. Az amerikai és az európai zöldút-tervezés modellértékű sajátosságai.....................................................28

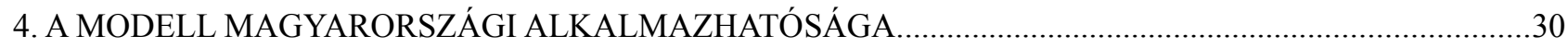

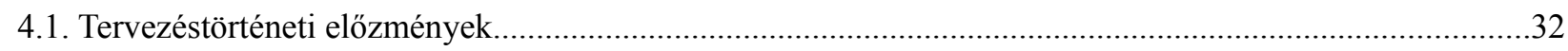

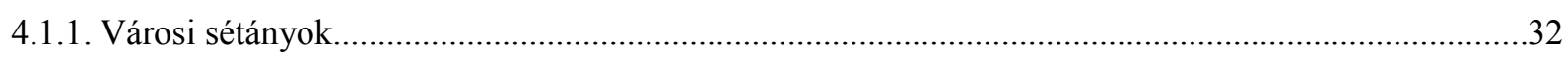

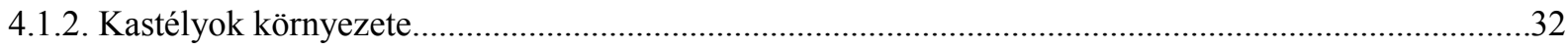

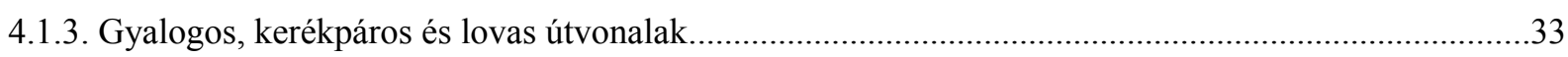

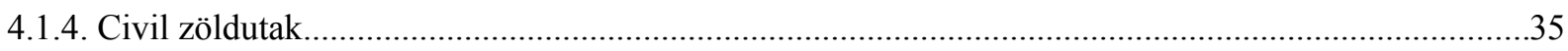

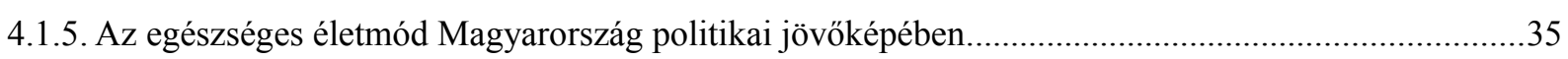

4.2. Táji adottságok vizsgálata a zöldút modell alkalmazhatósága szempontjából.............................................36

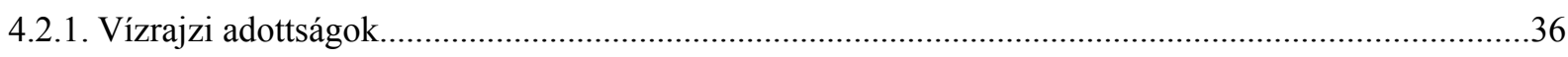

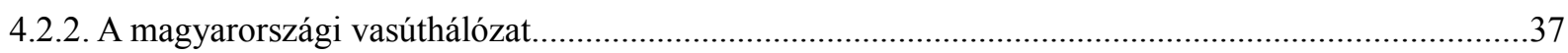

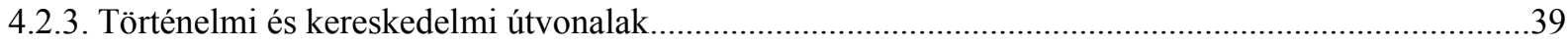

5. A ZÖLDÚT MODELL ALKALMAZÁSA A ZSÁMBÉKI-MEDENCE TERÜLETÉN....................................40

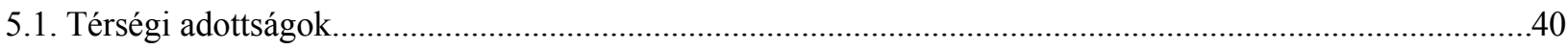

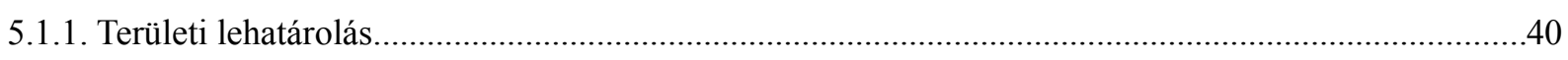

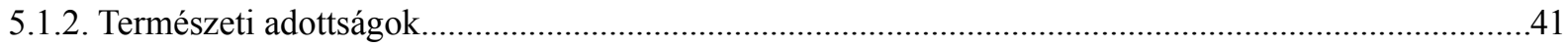

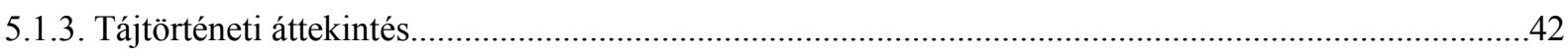

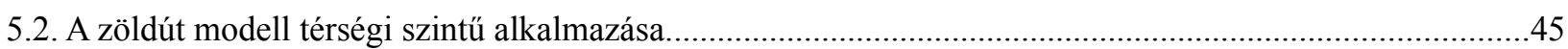




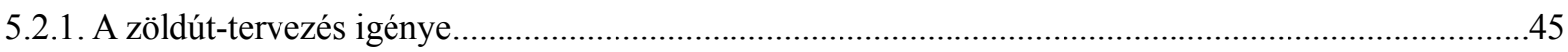

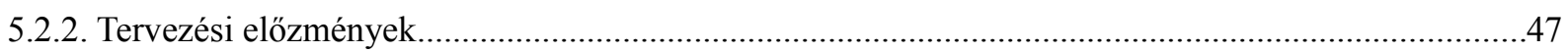

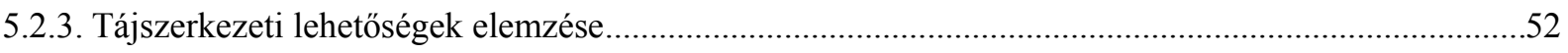

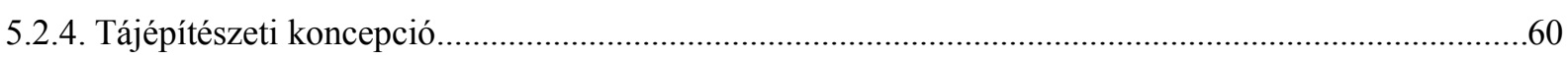

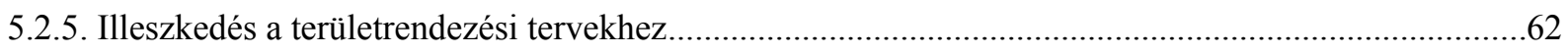

6. MAGYARORSZÁGI ZÖLDÚT-TERVEZÉS ALAPVETÖ METODIKAI ELEMEI........................................67

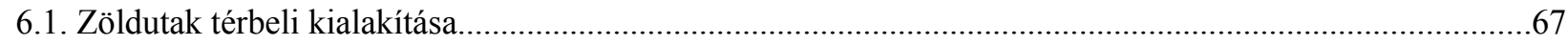

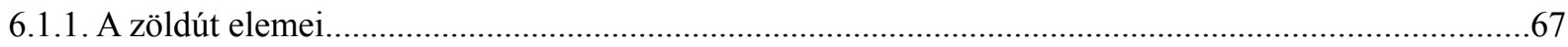

6.1.2. Zöldutak alapvető kialakítási lehetőségei a rekreációs és az ökológiai szerepü tájelemekkel

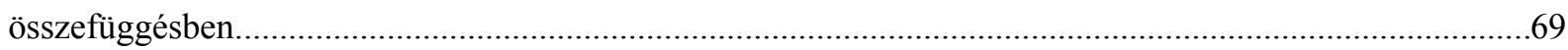

6.1.3. Zöldutak kapcsolódása a települések beépített területeihez...........................................................69

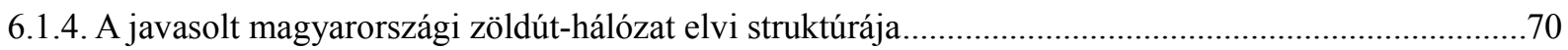

6.2. A zöldút fogalom tájépítészeti szempontú meghatározása.....................................................................70

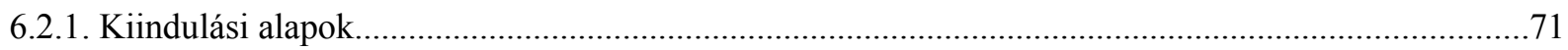

6.2.2. Civil szervezetek által megfogalmazott zöldút definíciók...........................................................72

6.2.3. A hazai területrendezési és településrendezési tervezésbe illeszthető zöldút definíció......................74

6.2.4. A javasolt zöldút fogalom és a zöldúttal rokon fogalmak kapcsolata...............................................75

6.2.5. A zöldút, valamint az ökológiai és a zöldfolyosó fogalmak kapcsolata............................................77

6.3. A zöldút-tervezés lehetséges helye a területrendezési tervezés rendszerében.........................................79

6.3.1. Kapcsolódás a területrendezési tervezés részeihez......................................................................79

6.3.2. "Zöldút kialakítására alkalmas övezet" képzésének megalapozása...............................................83

6.4. A térségi szintü zöldút-tervezés metodikai alapjai...........................................................................85

6.4.1. A zöldút-tervezési feladatok meghatározása a zöldutak tipizálásával................................................86

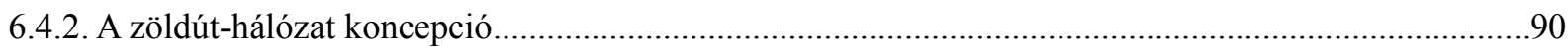

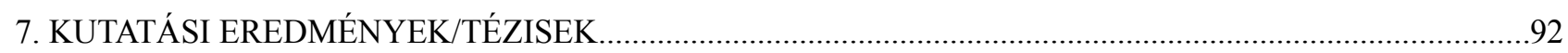

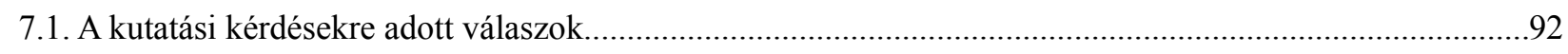

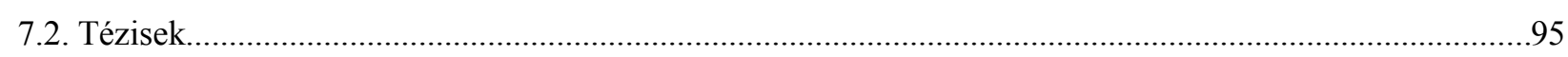

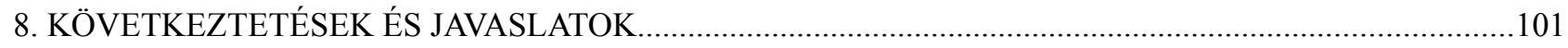

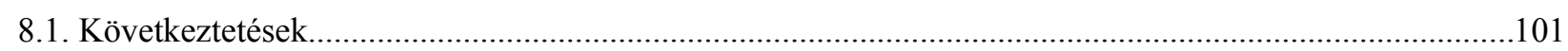

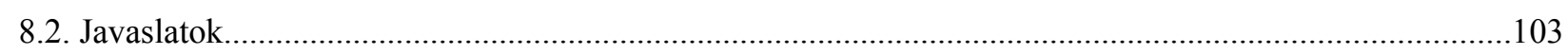

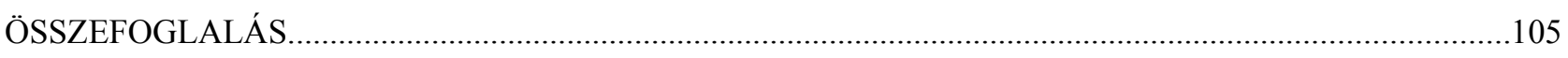

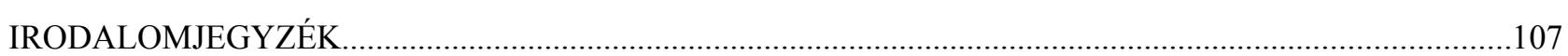

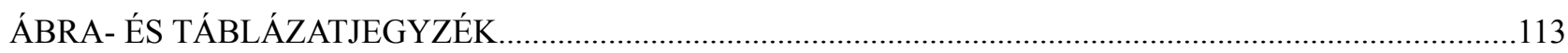




\section{BEVEZETÉS}

\subsection{A kutatási téma jelentősége}

Kutatásom a magyarországi zöldút-tervezés bevezetésére irányuló tájépítészeti kutatásokhoz kapcsolódik. A zöldút-tervezés témájában az első hazai kutatómunka Csemez Attila és munkatársai Dél-Budakörnyéki Green Belt (Zöld Öv) Pilot Projekt című tanulmánya volt, amelyben a szerzők értelmezték a nemzetközi szakirodalomban ismertté vált Green Belt (zöldöv) és Greenways (zöldút) fogalmakat, és vizsgálták a Budapest környéki zöldöv kialakításának tájépítészeti lehetőségét (CSEMEZ ET AL, 2000). A tanulmányt követő években a zöldút fogalom több tudományos munkában megjelent (ALMÁSI, 2007; FILEPNÉ KOVÁCS, 2013), több tudományos munka témájához kapcsolódik (BÁTHORYNÉ NAGY, 2007; SZILÁGYI ET AL, 2012). A Zsámbéki-medence területére készült féléves hallgatói feladat tapasztalatai alapján a zöldút-tervezés táji léptékü metodikai megalapozásának első javaslatait egyetemi jegyzet fejezete tartalmazza (SALLAY, BÁRCZINÉ KAPOVITS, 2010). A zöldút-tervezés az egyetemi oktatómunka részeként különféle léptékü hallgatói tervezési gyakorlatok és diplomamunkák témája volt. (KOLLÁNYI, 2014). A biatorbágyi felhagyott vasútvonal zöldfelületi fejlesztésére készült hallgatói tanulmány a zöldút-tervezés települési léptékü tervezésének mintájául szolgálhat (HUTTER ET AL, 2014).

A zöldút-tervezésre irányuló tájépítészeti kutatások aktualitása érzékelhető. A kilencvenes évektől kezdődően Magyarországon is robbanásszerűen felgyorsult a motorizáció, a városi környezetben egyre általánosabbá vált a mindennapos gépkocsihasználat. Ennek következtében folyamatosan nőtt a forgalom, fokozottan jelentkeztek a környezeti terhelések, egyre szélesebb körben jelent meg a mozgásszegény életmód. Ugyanakkor növekedett az igény a szabadidős tevékenységek iránt. Mindez ráirányította a figyelmet a rekreációs lehetőségek bővítésének szükségességére. 1990 és 2013 között 2000 km kerékpárút épült Magyarországon. A kerékpárutak kezdetben jellemzően a föforgalmi utak mentén épültek, később azoktól részben elszakadva, meglévő burkolt vagy burkolat nélküli szakaszokat is bekapcsolva létesültek új kerékpáros útvonalak. A legnépszerübb kerékpáros útvonalak (Balaton-körüli, Fertő tó körüli, Velencei-tó körüli, Tisza-tó menti, Duna menti) használata évröl évre látványosan növekszik.

A kerékpáros útvonalak bővülése mellett számszerüen kimutatható a gyalogos kirándulások népszerüsége is a teljesítménytúrákon résztvevők számának növekedésével (CSEMEZ, 2013). A lovaglás hagyománya is újjáéled, folyamatban van a Kincsem Nemzeti Lovasprogram kidolgozása. A meglévő és tervezett gyalogos, kerékpáros, lovas útvonalak összehangolása céljából megkezdődött a Bejárható Magyarország program kidolgozása. 
Számos településen azonban nem áll rendelkezésre a helyi lakosság vagy az odaérkező kirándulók számára könnyen elérhető, bármely életkorú használó számára biztonságos - lehetőleg a gépjármü forgalom veszélyeitől mentes, természeti környezetben haladó -, egy-két órás vagy egynapos kikapcsolódást jelentő gyalogos, kerékpáros kirándulási lehetőség. Egyes helyeken ugyanakkor már az a probléma jelentkezik, hogy a gyalogos, kerékpáros, lovas használat számára optimális útvonalak megegyeznek, így a kezdetben megfelelő szélességü utak többféle rekreációs használat számára szüknek bizonyulnak, többféle használatuk konfliktussal jár. Problémát jelentenek azok a gyaloglásra, kerékpározásra kijelölt útvonalak is, amelyek fátlan területeken vezetnek, és így nyári hőségben száraz, poros, árnyékmentes környezetükkel valódi kikapcsolódást nem nyújtanak. A természetes és a természetközeli területek kiránduló útvonalként való hasznosítása természet- és környezetvédelmi problémákat, ökológiai kérdéseket vet fel. A felsorolt helyzetekre adhat választ a zöldút-tervezés, amelynek célja a rekreációs és az ökológiai igények és korlátok komplex figyelembevételével történő, többféle rekreációs használatra alkalmas útvonalak és útvonalhálózatok tervezése.

A zöldút-tervezésre irányuló kutatói munkák és hallgatói gyakorlatok ellenére a zöldút-tervezés a gyakorlati tervezésben egyelőre nem jelenik meg. Aktuálissá vált az a kérdés, hogy a zöldúttervezés megjelenhet-e a gyakorlati tájépítészeti tervezésben. Tekintettel arra, hogy a rendszerváltást követően a tájtervezés müszaki-jogi szempontból a területrendezési és a településrendezési tervezésbe integrálódott, ezért a területi vonatkozású tájrendezési célú javaslatoknak a területrendezési és a településrendezési tervezés rendszerébe kell épülniük (SCHUCHMANN, 2007; GERZÁNICS, 2013). Értekezésemben az eddigi kutatások folytatásaként a zöldút-tervezés területrendezési és településrendezési tervezésbe való integrálásának lehetőségét vizsgálom, és a zöldút-tervezés magyarországi tájépítészeti metodikájának megalapozására vállalkozom.

\section{Kutatási feladatok}

Kutatásom megkezdésének oka a Zsámbéki-medencében társadalmi kezdeményezéssel javasolt Budavidék Zöldút tájépítészeti jelentőségének és fejlesztési lehetőségeinek feltárása volt. A társadalmi kezdeményezésnek aktív részese voltam. Az úthálózat kijelölése és használata során észleltem a program tájépítészeti jelentőségét, a fejlesztési lehetőségeket és a megoldandó tájépítészeti feladatokat.

Kutatásom elején a következő fő kérdésekre kezdtem keresni a választ:

— Hogyan lehetséges a Zsámbéki-medencében a Budavidék Zöldút Szövetség által gyaloglásra és kerékpározásra javasolt civil zöldút-hálózat szerepeltetése a tájépítészeti tervezésben annak 
érdekében, hogy a javasolt és egyre népszerübb útvonalak ne szünhessenek meg vagy ne szakadhassanak meg új beépítések miatt?

— Hogyan határozhatók meg a zöldút-hálózat optimális nyomvonalai és optimális keresztmetszeti kialakítási módjai?

Kutatásaim előrehaladtával a kutatási mintaterületül választott tájban észlelt tájhasználati összefüggések és fejlesztési javaslataim általánosíthatósága vált kutatásaim súlyponti részévé, így az eredeti kérdések köre jelentősen bővült. A kutatási kérdésekre adható válaszok keresése során a szakirodalmi előzmények feldolgozása és gyakorlati tapasztalatokon alapuló elemzéseim ötvözésével a kutatási téma országos léptékü tervezési metodika megalapozására irányult.

A vonatkozó szakirodalom megismerése alapján kutatásom alapjának a Frederick Law Olmsted tájépítészeti gondolatán alapuló zöldút modell elemzését tekintettem. A kutatás első részében a zöldút modell magyarországi alkalmazási lehetőségét vizsgáltam, majd arra alapozva elemeztem a zöldút-tervezés tájépítészeti megalapozásának meghatározó területi vonatkozású szempontjait. A következő kérdések megválaszolására kerestem a válaszokat:

- Alkalmazható-e - és milyen eltérésekkel és sajátosságokkal - a zöldút modell Magyarországon?

- Hogyan alkotható meg a hazai területrendezési és településrendezési tervezésbe illeszthető zöldút definíció?

— Hogyan határozható meg a zöldút-tervezés helye a hazai területrendezési és településrendezési tervezés rendszerében?

— Hogyan hangolható össze a zöldút-tervezés az egyéb szabadtéri rekreációs lehetőségek tervezésével?

- Hogyan hangolható össze a zöldút-tervezés az ökológiai folyosók védelmével, illetve fejlesztésével?

- Hogyan bővíthetik a civil zöldút mozgalom eredményei az olmstedi zöldút modellre alapozható tájépítészeti tervezési lehetőségeket?

\section{A kutatás célja}

Kutatásom célja új szabadtéri rekreációs alternatíva tervezésének megalapozása az olmstedi zöldút modell magyarországi alkalmazásával úgy, hogy a javasolt zöldút-tervezési metodika illeszkedjen a sajátos magyar táji adottságokhoz, valamint a jogrend részét képező területrendezési és településrendezési tervezés rendszeréhez.

A kutatási feladatként megfogalmazott kérdések megválaszolása során arra törekedtem, hogy kutatási eredményeim az előző tudományos eredményekre és a tájépítészeti tervezéstörténeti 
gyökerekre épüljenek, és a gyakorlatban is megvalósítható többszintü zöldút-tervezési folyamatot alapozzanak meg. Kiemelt célom a jogi-müszaki környezetbe illeszthető, a zöldút meghatározó térbeli jellemzőit tartalmazó definíció megfogalmazása annak érdekében, hogy a zöldút fogalom egyértelmü jelentéstartalommal jelenhessen meg a szakirodalomban és a gyakorlati megvalósításra irányuló tervezési folyamatokban. Különös figyelmet fordítok arra, hogy a civil szerveződésü zöldút programok területi vonatkozású eredményei minél jobban beépülhessenek a tájépítészeti tervezésbe, illetve a területrendezési és a településrendezési tervezés hierarchikus rendjébe.

\section{Anyag és módszer}

Kutatási módszereim a tudományos kutatások általános módszertani elemeire épülnek, melyeket kiegészítek a tájépítészet sajátos kutatási módszereivel. A tudományos megközelítés alapja a zöldúttervezés szakirodalmi feltárása. Elsőként elemeztem a zöldút-tervezés hazai bevezetésének tekinthető tájépítészeti tanulmányt (CSEMEZ ET AL, 2000), majd áttekintettem a témához kapcsolódó hazai tudományos publikációkat. A szakirodalomban fellelt források eredetiségük szerint elsődleges és másodlagos források, tartalmuk szerint pedig tervezéstörténeti, tudományos és civil szerveződésből származó források. Értékeltem a szakirodalomban, valamint a civil kezdeményezésü zöldút programokban említett zöldút fogalmak jelentéstartalmait, vizsgáltam a jelentésbeli azonosságokat és eltéréseket a területrendezési és a településrendezési tervezés fogalmainak, valamint az ökológia tudományos szóhasználatának tükrében. A kutatás fontos része a többszöri helyszíni bejárással megismert mintaterület tapasztalatokon alapuló elemzése.

A megismert külföldi források közül kiemelt figyelmet fordítottam a tájépítészeti megközelítésű, áttekintő jellegü publikációk elemzésére (FABOS, 1995; SEARNS, 1995; ZUBE, 1995; BisCHOFF, 1995). Ezek a források a zöldút-tervezés szempontjából elsődleges forrásoknak tekinthetők. Másodlagosak abban az értelemben, hogy a zöldút-tervezés kialakulására, a tervezéstörténeti előzményekre utaló hivatkozásokat tartalmaznak. E hivatkozások közül elemeztem azokat, amelyeket a magyarországi zöldút-tervezési metodika megalapozásához elvi alapokat nyújtanak.

A zöldút-tervezés meghatározó szakirodalmának áttekintése során az amerikai zöldút-tervezés kialakítását és gyakorlatát modellnek tekintem, és annak magyarországi alkalmazási lehetőségét vizsgálom. Ennek oka az, hogy minden további - európai és ázsiai -, tájépítészeti megközelítésü zöldút-tervezés forrása az Olmsted-féle zöldfelületi rendszer gondolatára épülő amerikai zöldúttervezés. A tapasztalatok alapján bizonyítottan müködőképes olmstedi zöldút modellre alapozva születnek meg a további kontinensek, országok táji sajátosságaihoz illeszkedő zöldút fogalmak és zöldút-tervezési metodikai változatok. Az eredeti tájépítészeti forrás modellnek tekintését azért is 
fontosnak tartom, mert a civil kezdeményezésü zöldút mozgalmak tevékenységében a helyi kezdeményezés, és ehhez kapcsolódóan a helyi közösségek erösitése kerül középpontba. A zöldutakban rejlő turisztikai lehetőségek miatt ugyanakkor fontosak a zöldutak területi vonatkozású jellemzői és várható hatásai, amelyeket a területrendezési és a településrendezési tervezés rendszerébe illeszkedő tájépítészeti tervezéssel szükséges feltárni.

A kutatás vizsgált anyagai:

— az olmstedi zöldút modell és fejlödése a szakirodalomban,

— az eddigi hazai zöldút-tervezésre irányuló kutatói és oktatói munka eredményei,

— a civil zöldút mozgalmak eredményei,

- a választott mintaterület táji adottságai,

- a hazai területrendezési tervezés rendszere,

— a hazai településrendezési tervezés rendszere.

Az alkalmazott kutatási módszerek:

— zöldút-tervezés szakirodalmának elemzése,

— a mintaterület tájépítészeti elemzése a zöldút modell alkalmazása szempontjából,

- a mintaterület többszöri személyes bejárása, tapasztalatok elemzése,

- konzultációk a mintaterületen érintett tulajdonosokkal és gazdálkodókkal,

— szakmai konzultációk,

— a mintaterületre vonatkozó vizsgálatok eredményeinek általánosítása és kiterjesztése,

— konferencia-részvételek tapasztalatainak összehangolása a kutatási témával. 


\section{IRODALMI ÁTTEKINTÉS}

\subsection{A zöldút fogalma a külföldi szakirodalomban}

A tájépítészeti szakirodalom a zöldút alapvető meghatározásának az amerikai szabadterek fejlesztése céljából, elnöki megbízással felkért munkacsoport által 1987-ben kidolgozott 'American Outdoors' címü tanulmányban szereplő jövőképet tekinti: "A zöldutak élő hálózata... elvezeti az embereket a környezetükben lévő szabadterekhez, összeköti az amerikai táj vidéki térségeit és szabadtereit... felfüzi a városokat és a vidéki területeket, mint egy óriási keringési rendszer. ${ }^{1 "}$ (LitTle, 1990, P. 93; FlincK And SEARns, 1993, P. XVII; FABOS, 1995, P. 1; TURNER, 2006, P. 242). A tanulmányban megfogalmazott zöldút fogalomhoz kapcsolódva a a Massachusetts állambeli Amherst-i Egyetemen tájépítészeti kutatómunka kezdődött zöldutak komplex tervezésének céljából. A kutatócsoport tagjai meghatározták a zöldút-tervezés gyökereit a régebbi korok kerttörténetére visszatekintve, majd a zöldutat ('Greenways') olyan lineáris, multifunkcionális tájépítészeti elemként határozták meg, amelynek legfontosabb szerepe a térbeli kapcsolatteremtés a területi kiterjedésű rekreációs és/vagy ökológiai jelentőségű szabadterek ('Green Spaces') között (FABOS, 1995; SEARNS, 1995; ZuBE, 1995; AHERN, 1995; BISCHOFF, 2004). A zöldutak multifunkcionalitása egyrészt a rekreációs és az ökológiai szerep együttes megjelenését, másrészt a többféle rekreációs használat (gyaloglás, kerékpározás, lovaglás) megfelelően széles sávban való együttes biztosítását jelenti.

A zöldút-tervezés legjelentősebb történeti előzményeként Frederick Law Olmsted tájépítész 'Emerald Necklace' néven ismert tervét határozták meg, amely 1880-ban valósult meg Bostonban, és amely a metropolisszá bővült városnak ma is meghatározó eleme (LITTLE, 1990, P. 10-11; FABOS, 1995, PP. 1-3; SEARNS, 1995, P. 68; BISCHOFF, 2004). A zöldút lényegét Olmsted újítása fejezi ki: a XX. század városépítészeti szokásának megfelelően mértani rendben tervezett parksétányok alternatívájaként a város egyik folyója mentén tervezett a folyómeder természetes vonalát követő tájképi stílusú sétányt, amelyet gyalogosok, kerékpárosok, lovasok és lovaskocsizók teljes hosszában zavartalanul, megszakítás nélkül használhattak. A sétányhoz kisebb zöldfelületek és nagyobb parkok is kapcsolódtak, így ezek városi jelentőségü zöldfelületi rendszert alkottak. Az 'Emerald Necklace' később Charles Eliot tervei szerint fokozatosan a megnövekedett Boston körüli zöldfelületi rendszerré bővült. Olmsted és Eliot tervei a XX. század második felében Amerikában kezdődött zöldút-tervezés alapjául és mintájául szolgáltak. Az Amherst-i Egyetem kutatócsoportja a

1 A living network of greenways ...to provide people with access to open spaces close to where they live, and to link together the rural and open spaces in the American landscape...threading throught cities and countryside's like a giant circulation system ( President's Commission on American Outdoors for the United States, 1987) 
parkrendszer további bővítéseként 1995-ben hat állam területét magába foglaló regionális zöldút koncepciót dolgozott ki 'New England Greenway Vision Plan' címmel.

A zöldút fogalom figyelemre méltó jelentéstartalma a zöldút ('Greenway') kifejezésnek két városépítészeti fogalom, a parksétány ('Parkway') és a zöldöv ('Greenbelt') szöösszetételéből való levezetése (BISCHOFF, 2004, TURNER, 2006). Bár a zöldút fogalom első megjelenésében (WHYTE, 1968) ez a jelentéstartalom nem - vagy feltehetően nem tudatosan - szerepel, a zöldút fogalom magában foglalja az elválasztott közlekedésü rendszerü fásított nagyvárosi sétány és a városkörnyéki területek beépítésének korlátozása céljából kijelölt zöldöv jelentéstartalmát is. A zöldövben kialakítható rekreációs szerepü zöldutak kialakítását legjobban London és Ottawa példája szemlélteti (THOMAS, 1963, TURNER, 1995, TAYLOR ET AL, 1995). London esetében a nagyváros körül kialakítható zöldút gondolatából fejlődött ki a Nagy London Tervben megjelenő - a beépítési lehetőségeket korlátozó - zöldöv kategória, Ottawa esetében pedig a nagyvárosi zöldövben jelentek meg később a rekreációs szerepet betöltő zöldutak.

A zöldútnak, mint multifunkcionális tájelemnek összetett szerepe és hatása lehet egy-egy adott táj társadalmi-gazdasági-környezeti adottságaitól függően. Éppen ezért a zöldutak alapvető meghatározásához igazodva a zöldút fogalom többféle változata megtalálható a szakirodalomban, amelyek a sajátos tájtörténeti előzményeket és az adott ország müszaki-jogi tervezési rendszerét is tükrözik. Ebben az értelemben tartoznak a zöldutak halmazába a kisebb vagy nagyobb folyók mentén létesített zöldutak, a vidéki tájakon vagy a XXI. századi metropoliszok területén megszünt vasútvonalak nyomvonalán létesített nagyvárosi zöldutak és egyéb, természetes vagy ember által alakított vonalas tájelemek mentén létrehozott, jelentős rekreációs és/vagy ökológiai szerepet betöltő zöldutak egyaránt.

\subsection{A zöldút fogalom megjelenése Magyarországon}

A zöldút-tervezés magyarországi bevezetése a 2000-ben a Szent István Egyetem Tájtervezési Tanszékén készült, Dél-Budakörnyéki Green Belt (Zöld Öv) Pilot Projekt címü tanulmányával kezdődött meg (CSEMEZ ET AL, 2000). A szerzők tanulmányukban értelmezték a nemzetközi szakirodalomban ismertté vált 'green belt' (zöldöv) és 'greenways' (zöldút) fogalmakat. Javaslataik során kiemelték az ökológiai- és zöldfolyosók ökológiai és rekreációs jelentőségét a Dél-Budakörnyék tájszerkezetében, különös tekintettel a Hosszúréti- és a Benta-patak mentére. A tanulmány egyike volt az első, tájépítészeti javaslatokat térinformatikai eszközökkel feldolgozó munkáknak. A térinformatikai alkalmazásokat - a tervezési folyamat különféle tartalmú rétegekben való feldolgozását - a zöldút-tervezéshez szükséges alapadatok és sokféle részfeladat egységes rendszerben való bemutatása tette szükségessé. 
Almási Balázs 2006-ban készült doktori értekezésében a magyarországi zöldhálózat tervezés metodikai fejlesztésével foglalkozott, amelyben tovább finomította a zöldfolyosó és a zöldút fogalmak meghatározását a települési zöldfelületi rendszerek tervezéséhez kapcsolódóan. Értekezésében a zöldhálózatot a zöldfelületi rendszeren belül, a közhasználatra szánt elemek alkotta rendszerként határozza meg. Téziseiben elválasztja a zöldfolyosó és a zöldút fogalmakat. A zöldhálózati rendszer egyes lineáris elemeinek ,megnevezését zöldútként vagy zöldsétányként javasolja (ALMÁsı, 2007).

A zöldút a tájépítészeti oktatás és kutatás során egyre gyakrabban használt fogalom, amelyben kiemelt jelentőséget kapnak a folyó- és patak menti területek, valamint a barnamezős városrehabilitációs területek. A kutatói és hallgatói munkákban a zöldútnak többféle megfogalmazása szerepel, de a megfogalmazások jelentéstartalma egyelőre nem egyértelmü. Elsősorban azért, mert a zöldút fogalomnak egyéb rekreációs és ökológiai jelentőségű tervezési fogalmakkal való kapcsolata nem tisztázott. A hallgatói munkák egy része az amerikai zöldút fogalom meghatározására, másik része az európai civil zöldút mozgalom által megfogalmazott definícióra alapozza munkáját. Ennek megfelelően az első típus jobban érinti a területrendezést, a másik különféle zöldútvonalak kiválasztására és a zöldutak szükebb és tágabb környezetére vonatkozó tájfejlesztési javaslatokkal foglalkozik. Mindkettő indokolt, de a zöldút-tervezés tájépítészeti meghatározása, célja, feladata ezért bizonytalan. A fogalmi tisztázás legfontosabb kérdése a Magyarországon a gyakorlati tervezésben is megjelenő zöldfelületi rendszertervezés, a tudományos értekezésben javasolt zöldhálózattervezés, az Európában uniós határozatban elfogadott ökológiai- és zöldfolyosó fogalmak, az egyfunkciós rekreációs útvonalak (a gyalogos-, a kerékpáros és a lovas útvonalak), valamint a nemzetközi szakirodalomban elfogadott zöldút fogalom közötti összefüggések feltárása.

A fogalmi tisztázás mellett fontos tisztázni azt is, hogy gyakorlati szempontból milyen igényekre adhat megoldást, illetve milyen tervezési újítást jelenthet a zöldút-tervezés Magyarországon. Ennek érdekében értekezésemben az olmstedi zöldút modell táji léptékü kiterjesztésével megvalósult amerikai zöldutak meghatározó térbeli jellemzőinek feltárására építve elemzem a zöldút modell magyarországi alkalmazási lehetőségét, különös tekintettel a tájtörténeti adottságokból és a hazai tervezési rendszer felépítéséből következő hasonlóságokra, eltérésekre és sajátosságokra.

A zöldút az Európában és Magyarországon az Európai Zöldutak Szövetségének irányelvei alapján támogatott civil mozgalmak névadója is. A civil kezdeményezésű zöldút fogalom meghatározásában a hangsúly a különféle motormentes közlekedésre használható útvonalak helyi kezdeményezéssel történő kijelölésén és a helyi közösségek támogatásán van 


\section{A ZÖLDÚT-TERVEZÉS MODELLJE}

A tájépítészeti szakirodalom tanulmányozása alapján bemutatom azt a zöldút modellt, amely Frederick Law Olmsted tájépítészeti gondolatán alapszik, és amelyet a világ számos országában alkalmaznak az adott táji és tervezéstörténeti sajátosságokhoz igazodóan. Tekintettel arra, hogy a tájépítészeti tervezés Magyarországon a területrendezési és településrendezési tervezésbe integrálódott, a zöldút modell hazai alkalmazása érdekében alapvetően szükséges a zöldút modell meghatározó térbeli jellemzőinek feltárása. Elsősorban a zöldút modell térbeli jellemzőinek feltárására törekszem, miközben kitérek a zöldút fogalom megjelenésének és a tájépítészeti tervezésbe történt bevezetésének meghatározó részleteire is.

\subsection{A zöldút-tervezéshez vezető tájépítészeti kutatások}

A zöldút-tervezéshez vezető tájépítészeti kutatások előzményeit és az első eredményeket Julius Gy. Fabos írja le "Introduction and overwiev" és "Greenway planning in the USA" címü cikkeiben (FABOS, 1995, 2004). Az amerikai kutatásokat megalapozó háttér megismerése céljából e cikkekben hivatkozott főbb elsődleges forrásokat is áttanulmányoztam.

\subsubsection{A tájépítészeti kutatások elözményei}

Julius Gy. Fabos az amerikai zöldút mozgalom indulásának és fejlődésének három fő tényezőjét emeli ki. Az első, meghatározó tényező az 1987-ben kiadott "President's Commission on American Outdoors for the United States" címü elnöki határozat, amely a Ronald Reagan elnök által felkért szakértői bizottság tanulmányára alapozva született meg. A tudományos élet és a civil szervezetek képviselőiből álló bizottság feladata az amerikai szabadterek állapotának elemzése, és arra alapozva a lehetséges jövőképet vázoló jelentés készítése volt. A tanulmányban kiemelt szerepet kapott a zöldút fogalmának meghatározása és a zöldút-hálózatok létesítésének szükségessége. Az elnöki határozat elfogadását követően a kormány jelentős állami támogatást különített el zöldutak létesítésére. A támogatásnak köszönhetően két év alatt több mint 500 zöldutat létesítettek az Egyesült Államokban, különféle kezdeményezések és tervek eredményeként. Noel Grove publicista 1990-ben, a National Geographic folyóiratban megjelent cikkében gyakorlati megközelítéssel bemutatja az amerikai zöldutakat, kiemeli előnyös hatásaikat és a létesítésük során tapasztalt konfliktus helyzeteket is (GROVE, 1990).

A zöldutak fejlődését és elterjedését elősegítő második fő tényező a zöldút mozgalommal foglalkozó publicisztikák rohamos gyarapodása volt. Három év alatt négy, különféle megközelítésü könyv jelent meg a zöldutak témájában. Charles Eliot 1990-ben megjelent 'Greenways for America' 
címü könyvének fô értéke a zöldút mozgalom népszerüsítése és a zöldút fogalom elnöki határozatnak megfelelö, gyakorlati szempontú értelmezése. Smith and Hellmund 1993-ban megjelent 'Ecology of greenways' címü könyve elsősorban a zöldút-tervezés ökológiai és természetvédelmi kérdéseivel és feladataival foglalkozik. Flink and Searns 1993-ban megjelent könyve átfogó tanulmány a zöldutak tervezési szempotjairól és kivitelezési megoldásairól. A szerzők kiemelik a természeti és a kulturális értékek szerepét a zöldút-tervezésben. Karen-Lee Ryan 1993-ban megjelent könyve a többfunkciójú zöldutak tervezését támogató tervezési segédletnek tekinthető. Julius Gy. Fabos kiemeli, hogy az irodalomban tükröződik egy átmeneti időszak a zöldút létesítések kusza helyzetétől a jól meghatározott zöldút-tervezés időszakáig. (FABOS, 1995)

Az első tájépítészeti megközelítésű irodalmi megjelenések konferenciakiadványok voltak. A Kansas Cityben 1991-ben tartott ASLA konferencián a zöldút-tervezéssel önálló szekció keretén belül foglalkoztak. A konferencia előadások témái a zöldút-tervezéshez kapcsolódó témák voltak: szabadtér tervezés, látványértékelés, fenntartható fejlődés, kivitelezési feladatok. Az előadások elsősorban az 1981-1991 között megjelent tudományos közleményekben, hírlevelekben, konferenciakiadványokban megjelent kutatási eredményeket mutatták be a zöldutak témájával összefüggésben.

1992-ben konferenciát szerveztek a Massachusetts-i Egyetem (UMASS) Tájépítészeti Tanszékének vezetésével. Legtöbben helyi civil szerveződésű zöldút kezdeményezéseket ismertettek, hat New England állambeli képviselő beszámolt az állami szintű zöldút-tervezési eredményekről, a kanadai résztvevők pedig bemutatták azt, hogy az ottawai zöldöv koncepció hogyan alakult át zöldút-tervezéssé három metropolisz területén.

A harmadik lényeges tényező a zöldút mozgalmat alkotó személyek szakmai befolyása, véleményformáló szerepe és az egyéni kutatási eredmények voltak. A Landscape and Urban Planning című folyóirat 1995-ös különszámában megjelent cikkek szerzőinek többsége egyértelmúen Frederick Law Olmstedet tekintette az első zöldút tervezőnek, a bostoni 'Emerald Necklace' zöldfelületi rendszer tervére hivatkozva. E tudományos megállapítás előzménye Krueckeberg megállapítása, aki 1983-ban Olmstedet az amerikai tájépítészet sétányfelfedezőjének nevezte. Fabos megállapítja, hogy Olmsted volt az első tájépítész, aki egy folyó medrét használta fel egy összefüggő parkrendszer alapjának.

\subsubsection{A tájépítészeti kutatások fejlödése}

Fogalomalkotás és tipizálás

A zöldút fogalom elsőként William Whyte 1959-ben megjelent "Securing Open Spaces for Urban America" című tudományos közleményében szerepelt (FABOS, 1995; BISCHOFF, 1995). A szerző a 
cikkben leírja, hogy a zöldút fogalom a Pennsylvaniai telekosztások során felmerült problémák megoldásaként született meg: a beépítésre kevésbé alkalmas, és ezért nehezen értékesíthető területek (pl. vízfolyások medre) hasznosítási lehetőségeit vizsgálva Edmund Bacon, a helyi építésügyi hivatal tervezője és munkatársai azt javasolták, hogy a nehezen értékesíthető szomszédos területek összekapcsolásával jelöljenek ki olyan új övezetet, amelyek hasznos területekké válhatnak akkor, ha azoknak rekreációs szerepet adnak. Ezt az övezetet nevezték 'greenway'-nek, zöldútnak. A javaslat legfőbb értéke a zsúfolt városi beépítést lazító szabadterek megőrzéséhez szükséges jogi háttér biztosítása volt. E koncepció megszületésében alapvető szerepe volt annak, hogy a befektetési szempontból értéktelen területekhez a lakófunkcióhoz hasznosan kapcsolódó - és hosszabb távon várhatóan bevételt is hozó - funkciót rendeltek. (WHYTE, 1959 ÉS 1968)

Whyte 1968-ban megjelent 'The Last Landscape' címü könyvében a helyi gazdálkodók és Karl Besser városi építész sikeresen megvalósított kezdeményezéseként említi a 'Santa Clara Greenway' patak menti sétányt, amely szintén a telekosztások problémáinak megoldásaként, rekreációs szerepü önálló övezetként jelent meg. Whyte könyvében az így létrejövő zöldutak sokrétű szerepét is megfogalmazza: e lineáris szabadterek kapcsolatokat teremtenek távoli objektumok között, nagy a relatív szegélyhatásuk, sokféle mozgás teréül szolgálnak (séta, futás, kerékpározás, lovaglás).

A zöldút fogalom első országos léptékü megfogalmazásának a már említett, 1987-es elnöki határozatban szereplő jövőkép tekinthető, amely szerint a zöldút az amerikai szabadterek kiemelten fejlesztendő eleme, amely az élő szervezet keringési rendszeréhez hasonlít, összekötő szerepet tölt be a városi és a vidéki táj között.

Az elnöki határozat értelmében alakult zöldutak szerepe sokféle volt. A sokféleséget érzékelve Charles Little környezetvédelmi publicista "Greenways for America" címü könyvében a zöldutakat öt csoportba sorolta: városi, folyómenti zöldutak, rekreációs zöldutak, ökológiai jelentőségü természeti folyosók, tudományos vagy történelmi jelentőségű zöldutak, nagyszabású zöldúthálózatok. Noel Grove publicista cikkében szintén csoportosítja a zöldutakat: jelentőségük szerint megkülönböztet környezetvédelmi, ökológiai, oktatási és mindennapi mozgáslehetőséget szolgáló zöldutakat.

Julius Gy. Fabos és munkatársai tájépítészekként kezdtek foglalkozni a zöldutak szerepével és lehetőségeivel. Az elnöki határozatra alapozva a zöldutak olyan hálózatát vizionálták, amelyek az autópálya - és vasúthálózatokhoz hasonlóan átszövik a tájat, és a nemzeti, a regionális és a helyi térképeken és terveken egyaránt szerepelnek. A zöldutak esetében az utak nem keskeny sávok, hanem változó szélességü folyosók, melyek az egyéb útvonalakhoz hasonlóan infrastruktúra hálózatot alkotnak (FABOS, 1995. P.). Lényeges, hogy a zöldutak elsősorban a természet által kialakított nyomvonalakon (elsősorban a folyó- és patakvölgyekben) jelenhetnek meg. Olyan 
területeken, amelyek legtöbbször környezetileg érzékenyek, így speciális védelmük, illetve kezelésük is a tervezés részét képezi. Fabos és társai a zöldutakat három típusba sorolták: ökológiai, rekreációs és kulturális értékeket összekötő zöldutakra.

A zöldutak egyre szélesebb körü használatával a zöldutak egyre inkább multifunkcionális tájelemekké váltak. A multifunkcionalitás következtében túlságosan általánossá váló fogalom kezelhetősége érdekében Jack Ahern fontosnak tartja az egyes zöldutak domináns funkciójának meghatározását és annak megfelelő tervezését (AHERN, 2004). A zöldutak egyre összetettebb funkcióit észlelve Jongmann és Pungetti megkülönböztet ökológiai hálózattervezést és zöldúttervezést, és a zöldutak tervezésénél is javasolják az ökológiai rendszer-szemlélet alkalmazását (Jongmann AND PungetTi, 2004)

\section{Tervezéstörténeti gyökerek feltárása Robert M. Searns munkáiban}

A zöldút-tervezés szakirodalmában meghatározó jelentőségűek Robert M. Searns kutatásai, melyeket "The evolution of greenways as an adaptive urban landscape form" címü cikkében foglal össze. A zöldutak tervezéstörténeti előzményeit kutató Searns kutatásai a zöldút fogalom jelentéstartalmának és a tervezésben betölthető szerepének tisztázását is szolgálják.

Robert M. Searns megállapítja, hogy a XX. században Amerikában alakuló zöldutak nemcsak egy új, népszerü jelenségnek, hanem ősi emberi igényre adott válasznak és évszázados tájelemnek tekinthetők. Európai, ázsiai és az amerikai példákkal szemlélteti azt, hogy a zöldútnak tekinthető tájelemek az adott kor által meghatározott körülményeknek és igényeknek megfelelő formákban jelentek meg. Searns a zöldút-tervezés gyökereit az ókori Róma kultúrájáig, az első fasorok ültetéséig vezeti vissza. A későbbi korok kertépítészeti kultúrájából kiemeli a reneszánsz kori folyómenti sétányok és a barokk kertek körüli, táji léptékű fasorok szerepét. Kiemeli Párizs példáját, ahol a Szajna-parti fásított sétány a XXI. századi metropolisz terv meghatározó eleme. (SEARNS, 1995)

A zöldút, mint a városokban megjelenő tájelem fejlődésének három szakaszát állapítja meg. A legősibb formának a fasorokat, sétányokat és a parksétányokat tekinti. A zöldutak második megjelenési formáját azok a rekreációt szolgáló útvonalak jelentik, amelyek a folyók, patakok, vasúti nyomvonalak és egyéb lineáris tájelemek mentén létesíthetők. A harmadik megjelenési forma a multifunkcionális zöldút, amelynek szerepei a rekreáció mellett az állati élőhelyek biztosítása, az árvízkárok csökkentése, a vízminőség javítása, a szabadtéri oktatás a városi infrastruktúra részeként.

Searns azt is megjegyzi, hogy a multifunkcionális zöldutak tervezéséhez és létesítéséhez több szakterület - mérnöki, tájépítészeti, ökológiai - együttmüködése, a különféle szakterületi szempontok összehangolása szükséges(SEARNS, 1995). 


\section{Doktori értekezések}

Tudomásom szerint eddig a zöldút-tervezés témájában három doktori disszertáció született.

— Az első Luis Ribeiro portugál tájépítész munkája. 1998-ban készült disszertációjának címe "A kulturális táj és a hely egyedülállósága", melyben a zöldút-tervezés módszereit alkalmazza Lisszabon metropolisz területén, a kulturális örökségek hálózatának megőrzése érdekében.

— Jack Ahern 2002-ben készült disszertációjának címe "A zöldutak, mint stratégiai tájépítészeti tervezés: Elmélet és gyakorlat", melynek fő gondolata, hogy a zöldút-tervezés meghatározó, stratégiai szerepet és fontos kiindulási alapot jelenthet minden tájépítészeti tervezésben.

— Anne Lusk 2002-ben készült munkájának címe "Zöldút irányelvek, távolságok meghatározása, emberi tulajdonságok és igények találkozása a zöldutakon", amelyben kiemelten foglalkozik a zöldutak társadalmi, közösségi szerepével. (FABOS, 2004)

\subsection{Megvalósult példák}

\subsubsection{Boston zöldút-hálózatának fejlödése Olmsted tervétöl napjainkig}

A zöldút-tervezés elözménye: a parkway-tervezés

A zöldút-tervezés alapvető tájépítészeti előzményeként tekintett 'Emerald Necklace' terve előtt Olmsted parksétányokat tervezett New Yorkban és Bostonban, saját visszaemlékezései szerint az európai fővárosok (Párizs, London) fásított bulvárjainak inspiráló hatására. Ezek a parksétányok a városi szövet többfunkciós elemeiként jelentek meg, fasorokkal elválasztott rendszerü széles sétányokként gyalogosok, lovaskocsik és kerékpárosok számára (FEIN, 1968).

A 'parkway', mint meghatározó városépítészeti elem tervezésének első megjelenését Olmsted és Vaux két korai tervében lehet felfedezni. A tervezőpáros 1860-ban kapott megbízást a Strawberry Creek Valley területének megtervezésére. A tervezői feladat az volt, hogy teremtsenek „,egy kisebb parkélményt” a városban úgy, hogy kössék össze a meglévő parkokat a beépített városi területekkel. 1865-ben pedig megbízást kaptak a Berkeleyben található College of California campus és a Oakland város közötti városépítészeti kapcsolat megteremtésére. „Park and Piedmont Way” címü tervükben a feladat megoldásaként a két terület között széles, kellemes, árnyékos szekérutat terveztek, amellyel összekapcsolták a meglévő városi szabadtereket is. A parkwaytervezés kiteljesedését az Olmsted számára különösen kedvelt feladat, a Brooklyn Parkway tervezése jelentette, 1866-ban. A New York legjelentősebb külvárosában tervezett parkway szerkezetében jól felismerhető a séta - és szekérutak elválasztott rendszerü, fasorokkal tagolt kialakítása. (LITTLE, 1990))

Lényeges, hogy a 'parkway' eredeti, XIX. századi funkcióját tekintve gyalogosok, 
kerékpárosok, lovaskocsizók számára tervezett útvonalakat egyaránt magába foglaló városépítészeti elem. A szóösszetétel első eleme, a 'park' szócska arra utal, hogy az útvonalak parkokat kötnek össze, a 'way' szócska többfunkciós utat jelent. A XX. század óriási közúti fejlesztései során az eredeti 'parkway'-ek nagy részét többsávos autópályává szélesítették, így azok a gépjárműforgalmat kiszolgáló egyfunkciós útvonalakká váltak. (BISCHOFF, 1995)

\section{Frederick Law Olmsted tájépitészeti újitása Boston városépitészeti fejlesztésében}

Az első zöldútnak tekintett 'Emerald Necklace' bemutatását a rendelkezésre álló szakirodalom és a 2013. áprilisi 'Fabos Conference on Greenway Planning' programjaihoz kapcsolódó bostoni tanulmányi kirándulás személyes élményei alapján teszem meg. Az 'Emerald Necklace' zöldfelületi rendszer különféle nagyságú, jellegü és szerepü zöldfelületi elemeket foglal magába úgy, hogy az egyes elemeket lineáris zöldfelületként megjelenő széles sétányok kapcsolják össze.

Julius Gy. Fabos megállapítja, hogy Olmsted volt az első tájépítész, aki egy folyó medrét használta fel egy összefüggő parkrendszer alapjának (FABOS, 1995). Újítása az volt, hogy a sétálás, lovaskocsizás és kerékpározás számára nem az addig megszokott, mértani rendszert alkotó parksétányt, hanem a tájban természetes elemekként megjelenő patakok, folyók kanyargó vonalához igazodó utakat tervezett. Az 'Emerald Necklace' tervében Olmsted a parksétányokhoz hasonlóan többféle használatra tervezett széles sétányokat, de nem a beépített területek közötti városszövetbe vágva, hanem a természetes vízpartok mentén, a meglévő fás állomány árnyékában, részben elválasztott rendszerben, részben közös használatra is alkalmas, megfelelően széles sávokkal (1. ábra).

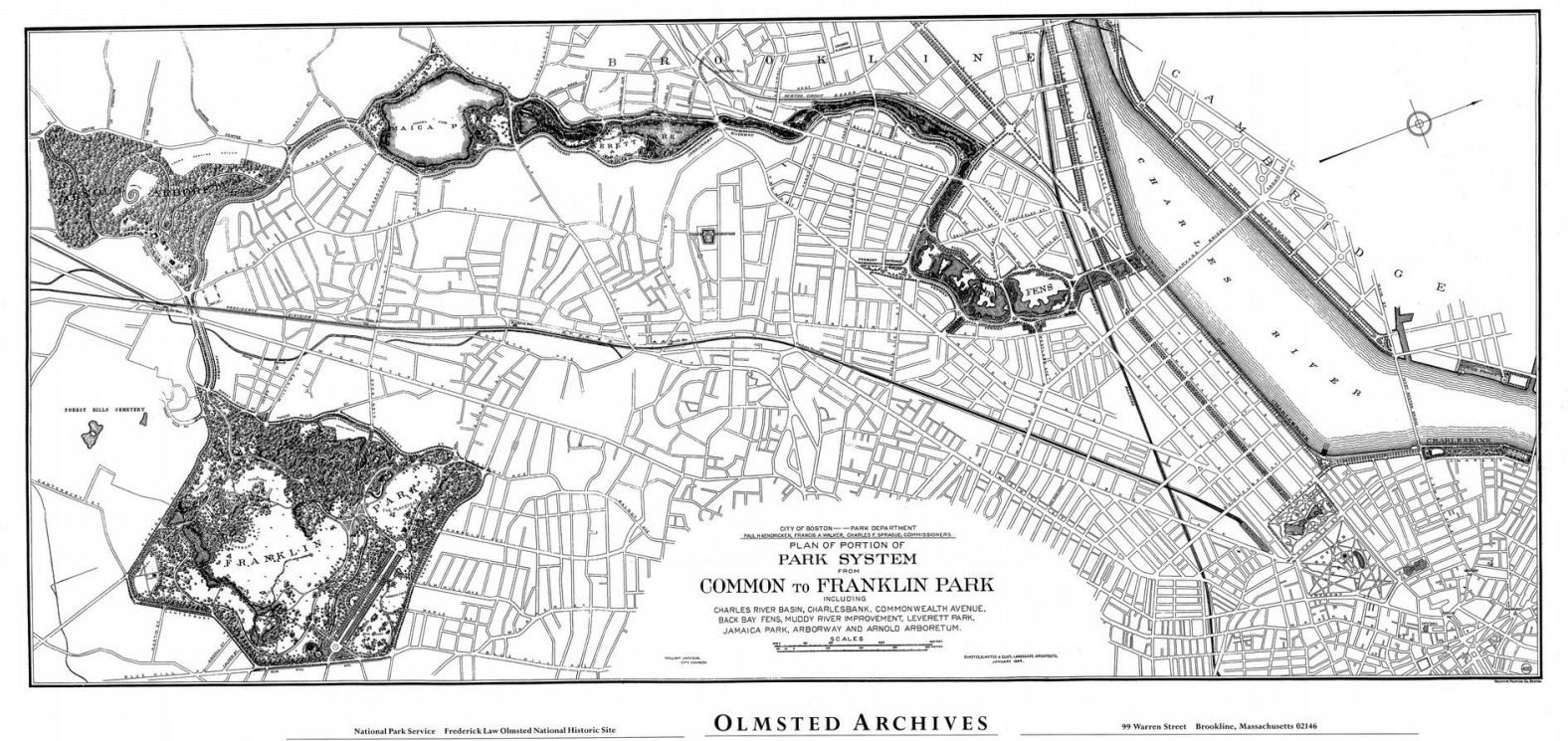

1. ábra: Olmsted parkrendszer terve Boston városi közparkjától a Franklin parkig, 1894 (forrás: wikipedia.org) 
Az Olmsted tervei szerint megvalósult parkrendszer mentén a mintegy 8 km hosszú, változó szélességü, a patak vonalához igazodóan tájképi stílusú, alapvetően lineáris, de több helyen, kisebbnagyobb mértékben kiszélesedő rekreációs szerepü zöldfelület jött létre. A zöldutat külön szinten keresztező, más közlekedési módok biztosítását szolgáló, kőből épült hidak, lépcsők, átjárók, kilátóhelyek az 'Emerald Necklace' sajátos karakterét meghatározó elemek. A sétányhoz különféle zöldfelületek kapcsolódnak, melyeket Olmsted tudatosan nem nevezett egységesen parkoknak, hanem sajátosságaikra utaló kifejezésekkel nevezte el azokat: 'Back Bay Fence', 'River Way', 'Jamaica Pond'.

Az 'Emerald Necklace' építése idején a város akkori peremén helyezkedett el, környezete csak részben volt beépített. Jelenleg a metropolisszá nőtt Boston központi részének meghatározó eleme. Jelentőségét - és Olmsted tervezői zsenialitását - mutatja, hogy a zöldút eredeti nagyságában és szerkezetében a XXI. századra is fennmaradt, eredeti szerepét a megváltozott városi struktúrában is megőrizte, és létezése a folyó menti területek széles zöldfelületként való megőrzését is biztosítja.

Az Olmsted által tervezett 'Emerald Necklace' modell értékü tájépítészeti sajátosságait a következőkben foglalom össze:

— természetes tájelem (patak) menti zöldfelületi fejlesztés,

— ökológiai és rekreációs szerep együttes megjelenése,

- kétféle nemmotoros használatra alkalmas útvonal,

— változó szélesség az adottságoktól és a a lehetőségektől függően,

— a teljes területen megszakítás nélkül használható lineáris zöldfelület,

— sajátos karakter megteremtése épített kerti elemekkel,

— különféle nagyságú, jellegű és szerepű zöldfelületi elemek kapcsolása a lineáris szakaszokhoz,

— Boston további bővülése során meghatározó városépítészeti elemként prioritást kapott a megőrzése.

\section{Boston zöldfelületi rendszerének regionális léptékü fejlesztése}

Olmsted tanítványa, Charles Eliot - a Fővárosi Park Bizottság tájépítészeként - Olmsted tervét kiterjesztette a teljes Bostoni metropolisz régió mintegy $600 \mathrm{~km} 2$ területére. Eliot terve szerinti parkrendszer öt nagy parkot kapcsolt össze és öt kisebb folyót is érintve eljutott az óceánig. A parkrendszer kiterjesztése Charles Eliot unokaöccse, Charles Eliot II. nevéhez kötődik. Charles Eliot II. 1928-ban - Massachusetts állam kormányzója Szabadtér Bizottságának tájépítészeként készített tervében a mintegy 250 km hosszú zöldsáv kialakítását javasolja, amely körülveszi Boston területét és összekapcsolja a régió legnagyobb víz borította területeit és vízgyüjtő területeit. Terve sokáig nem valósult meg, mégis olyan hatásos és logikus volt, az 1980-as és 90-es években számos 
szakaszán kiépültek a parkokat összekötő útvonalak. (FABOS, 2004)

\section{A New England Vision Plan}

A hat államot magában foglaló New England régió zöldút koncepcióterve 1999-ben készült a Massachusetts-i Egyetem Tájépítészeti Tanszékén, Julius Gy. Fabos, Mark Lindhult és Robert Ryan vezetésével, $10 \mathrm{MsC}$ diploma előtt álló hallgató bevonásával. A terv fó célja az volt, hogy sarkallják, serkentsék a tájépítészeket arra, hogy bekapcsolódjanak a zöldút mozgalomba. A mintaprojekt Olmsted és Eliot által tervezett parkrendszerek kiterjesztését jelentette, amelyben az újítást a meglévő parkok és szabadterek zöldutakkal való, regionális szintű összekapcsolása jelentette. (2. és 3. ábra)

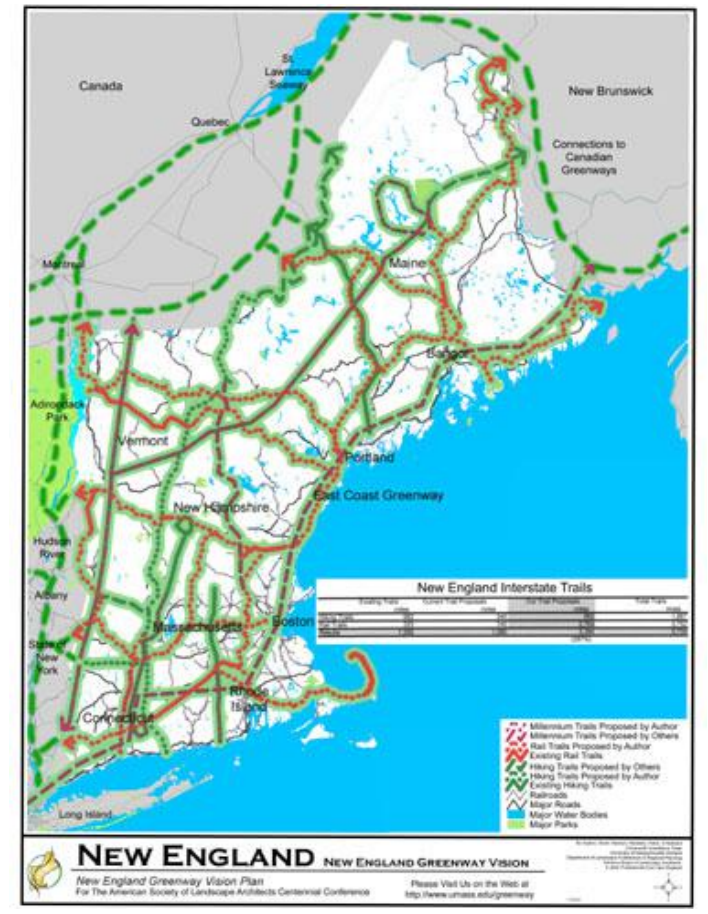

2. ábra: Zöldút hálózat koncepció a New England régió területére (forrás: www.umass.com)

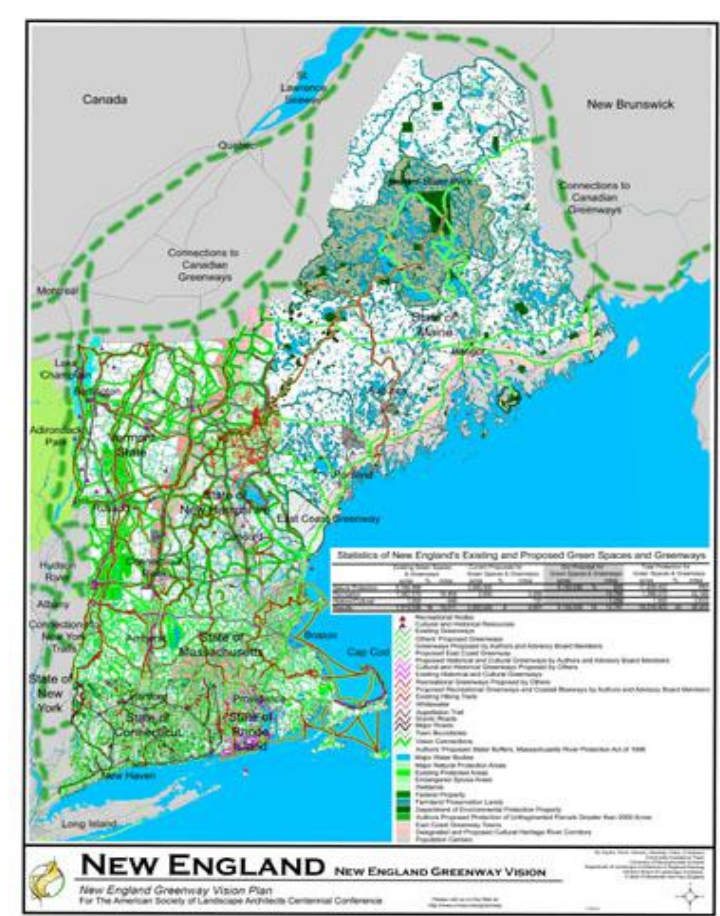

3. ábra: Meglévö és tervezett rekreációs útvonalak és zöldterek New England régió területén (forrás: www.umass.hu)

A tervezési folyamat öt lépésben történt:

— meglévő zöldutak és zöldterek kutatása és térképi ábrázolása, beleértve a kirándulóútvonalakat, vasúti nyomvonalakat figyelembe véve természetvédelmi, a rekreációs és kulturális örökségüket;

— az összes jelenlegi tervezési javaslat kutatása és térképi ábrázolása, amelyek növelik a zöldutakat és zöldtereket mindhárom kategóriát tekintve;

— kapcsolatok létesítése az összes zöldút típus között minden tervezési szinten (országos és regionális szinten); 
— önálló természetvédelmi, rekreációs, kulturális értékek, kiránduló útvonalak és felhagyott vasúti nyomvonalak szerepeltetése;

— átfogó zöldút koncepcióterv készítése, amely egyesíti az összes meglévő és folyamatban lévő és javasolt zöldút és zöldtér tervet és számszerü adatokat nyújt kilométerben a zöldutakról és hektárban a zöldterekröl.

A kutatócsoport térképen ábrázolta az összes zöldutat és szabadteret, majd összegyüjtötte az aktuális javaslatokat a kormányzati, nem kormányzati szervezetektől és egyénektől. Végül a kutatócsoport javaslatokat dolgozott ki, amelyek egy ideális zöldút-hálózat megvalósítására irányultak az USA területére vonatkozóan (nemzeti szinten). Ez a terv védelmet javasolt a nemzeti szinten jelentős környezetileg érzékeny folyosóknak és a zöldterületeknek. A terv az USA lakossága számára a rekreációs lehetőségek bővülését kínálta, valamint a nemzeti szinten jelentős történelmi és kulturális folyosó helyreállítását javasolta.

\section{Boston metropolisz zöldút-hálózatának további fejlesztési javaslatai a XXI. század elején}

Peter G. Furth és társai tanulmányukban a bostoni régióban megvalósult zöldutak felmérése alapján javaslatokat tesznek a zöldutak összefüggő hálózattá fejlesztésére a zöldutak közötti kapcsolatok létrehozása és további zöldutak létesítése által. (FURTH ET AL, 2013)

A szerzők alapvető problémának tekintik, hogy a városi zöldutak nincsenek kapcsolatban egymással, illetve azt, hogy a zöldutak használóinak gyakran forgalmas utakon kell áthaladniuk ahhoz, hogy az egyik zöldúttól a másikig eljussanak. Megállapítják, hogy a Bostoni régió területén szükség van olyan zöldút-hálózatra, amely folyamatosan, kellemes környezetben haladva összeköti a zöldutakat az egész város területén. Az egész régiót átszövő hálózathoz fel kell használni a meglévő zöldutakat és szükség van új szakaszok létrehozására is.

Javaslataik megfogalmazása előtt ismertetik a meglévő bostoni zöldutakat létesítésük időrendi sorrendjében: 1960-ra négy zöldút létesült Bostonban: az óceán, a Charles folyó, a Mystic folyó és a Muddy folyó partján. (A Muddy parti zöldút az Emerald Necklace, amely az első amerikai zöldútként ismert). 1967-1972 között két új zöldút létesült: South West Corridor az autópálya átépítések kapcsán, Minuteman/Community Path Corridor a felhagyott vasútvonalak hasznosításaként, és ahhoz kapcsolódóan négy, részben megépült zöldút: Neponset, East Boston, Watertown Branch, Northern Strand).

A meglévő zöldutak közötti kapcsolatok pótlására a területi adottságok figyelembevételével történő mérnöki megoldások kidolgozását javasolják. A zöldút-hálózat bővítésére új nyomvonalak kijelölésére tesznek javaslatokat:

— hat új zöldút felhagyott vasúti nyomvonalon, 
— 1910-1950 között tervezett (történelmi) parkway-ek nyomvonalán, az autós forgalmi sávok csökkentésével (a történelmi parkway-ek nagy része autópályává alakult a XX. században),

— autóutak forgalmi sávjainak csökkentésével, a forgalmi adatok elemzése alapján,

— új útvonaljavaslatok a meglévő parkok területén keresztül vagy azok szélén (javasolják például a Rose Fitzgerald Kennedy Greenway kerékpáros sávval való bővítését),

— vízvezetékek nyomvonalain.

A szerzők fontosnak tartják a zöldutak fö ismérveinek meghatározását. A bostoni régió táji, városépítészeti, közlekedési adottságainak feltárása alapján a zöldutak ismérveit a következőkben határozzák meg:

— zöld vagy kék sávban kell haladniuk: parkon át vagy park szélén vagy vízmenti sávban;

— a motoros közlekedéstől fizikailag el kell különülniük;

— alkalmasnak kell lenniük mind gyalogos, mind kerékpáros közlekedésre (kivéve a hegyikerékpárokat);

- legyenek legalább három mérföld hosszúságúak az egyes szakaszok.

A szerzők a fó ismérvek meghatározása mellett megállapítják a zöldút-hálózatok és a kerékpárút hálózatok kapcsolatát:

— átfedés lehetséges a zöldutak és a kerékpárút hálózat között, de nem azonosak;

— a kerékpárutak sok esetben nem zöldek, nem feltétlenül alacsony forgalmúak;

— a zöldutak több funkciósak: alkalmasak gyaloglásra, futásra, és egyéb rekreációs tevékenységekre, valamint környezetvédelmi és ökológiai szerepet is betöltenek.

A tanulmány szerzői megállapítják, hogy a parkok összekapcsolása régi tervezési cél, és a jelenlegi kerékpározási igények új ösztönzést adhatnak ennek a célnak. A bostoni régió zöldúthálózati fejlesztésében olyan újszerü, radikális mérnöki megoldások alkalmazását is javasolják, amelyek hangsúlyozzák a kerékpáros közlekedés megfelelö feltételeinek prioritását, akár a közúti közlekedés térbeli kereteinek szükítésével - például forgalmi sávok megszüntetésével - is.

(FURTH ET AL, 2013)

\subsubsection{Az olmstedi gondolat hatása a londoni zöldöv fejlödésére}

A nagyvárosok környezetében kialakított zöldövek klasszikus példájának tekinthető 'London Green Belt' történeti fejlődésében jól nyomon követhető a 'Parkway' és Greenbelt' fogalmak szoros kapcsolata, melyet David Thomas "London's Green Belt: The evolution of an idea" címü cikke alapján mutatok be. (THOMAS, 1968).

A londoni zöldöv létrejöttének első lépcsője a városkörnyéki szabadterek parksétányokkal való összekapcsolásának gondolata volt. A nagyvonalú javaslathoz az ihletet Meath - a London Megyei 
Tanácsülés Parkok és Szabadterek Bizottságának első elnöke - 1890-ben tett Bostoni utazása adta, ahol minden bizonnyal az Olmsted és Eliot által tervezett, 'Emerald Necklace' láncolatával találkozhatott. A következő évtizedben hasonló előterjesztéseket nyújtott be William Bull parlamenti képviselő és George Pepler városépítész is. Meath javaslata a bizottsághoz benyújtott hasonló javaslatok során alakult át úgy, hogy a fásított sétányok tervezett szélességének növelésével város körüli ligetes erdősáv terve fogalmazódott meg. Mindhárom terv fö tartalma a városkörnyéki szabadterek összekapcsolása parksétányokkal, jelentős eltérés csak a javasolt ligetes sáv szélességében és a beépített területek határától való távolságban volt.

Zöldfelületek tervezési lehetőségét tekintve mérföldkövet jelentett az az 1919-es törvényi lehetőség, amely lehetővé tette két vagy több hatóság együttműködését közös terv készítése érdekében. 1927-ben megalakult a Nagy London Regionális Tervezési Bizottság, amely London 25 mérföld sugarú körzetében lévő helyi hatóságok képviselőiből állt. A bizottság elnöke Raymond Unwin volt. 1933-ban Unwin a bizottság elnökeként javasolta egy London körüli zöldöv kijelölését, amely a korábbi változatoknál jóval szélesebb - néhány helyen 6 mérföld szélességű - volt, és amelynek fö célja már nem sétányok kijelölése, hanem a városkörnyéki területek beépíthetőségének korlátozása volt.

1935-ben London Megyei Tanácsülése kezdeményezte a város zöldövezeti tervének elkészítését, amelynek céljaként a rekreációs szabadterek biztosítását határozták meg. A terv megvalósítása céljából a megyei tanácsülés felajánlotta, hogy adománnyal segíti a szomszédos helyi önkormányzatokat abban, hogy - a káros beruházások elkerülése érdekében - megvásárolhassák a szabadtereket és a mezőgazdasági területeket. Mivel a javasolt zöldövhöz tartozó összes terület megvásárlásához nem volt elegendő anyagi háttér és szervezettség, a tanácsülés előterjesztést nyújtott be a parlament számára, amelyben kérte az Unwin által javasolt zöldövhöz tartozó területek védelmének biztosítását. 1938-ban a Parlament elfogadta a Londoni Zöldöv Törvényt.

1944-ben a Város - és Vidékfejlesztési Miniszter felkérte Patrick Abercombie-t a Nagy London Terv elkészítésére. A terv egy 10 mérföld széles zöldöv létrehozására tett javaslatot, ugyanakkor többet jelentett egy ligetes zöldsáv megörzésénél. Abercombie céljai - Howard kertvároskoncepciójának megfelelően - szélesebb körüek voltak:

- a szabályozatlan városi terjeszkedés korlátozása,

— a mezőgazdasági termesztés támogatása,

— rekreációs lehetőségek kidolgozása,

- a természet szépségének hangsúlyozása.

1947-ben a terv elfogadását miniszteri nyilatkozattal erösítették meg, és a törvényhozás 
engedélyezte Abercombie tervének megvalósítását.1947-ben elfogadták a Város - és Vidékfejlesztési Törvényt is, amelynek értelmében a minisztérium általános vezetése alá tartozó helyi hatóságok kötelesek voltak területükre fejlesztési terveket készíteni, amelyben a táji adottságokat kiemelten figyelembe kellett venni. A Nagy London Terv jelenleg is meghatározó céljai:

— a beépített területek túlzó mértékü növekedésének megakadályozása,

— két szomszédos város összenövésének megakadályozása,

— a városok sajátos karakterének megörzése.

A londoni zöldöv területén egészen kivételes körülmények kivételével jelenleg sincs lehetőség új épületek építésére vagy meglévő építmények átépítésére. A zöldövben csak mezőgazdasági, sport, temető területek kijelölése engedélyezett, ugyanakkor széles lehetőségeket biztosít a mezőgazdasági és rekreációs területek fejlesztésére.

\subsubsection{Az ottawai zöldöv kijelölésének hatása a kanadai zöldutak létesítésére}

A kanadai zöldutak tervezéstörténeti hátterét James Taylor, Cecelie Paine és John Fitz Gibbon elemzése alapján mutatom be (TAYLOR ET AL, 1995). A szerzők négy kanadai mintaterületen tárják fel a zöldövek és a zöldutak létesítésének szemléletbeli, tartalmi, formai, jogi-közigazgatási és végrehajtási szempontjait, lehetőségeit és határait. A négy mintaterület léptéke, az alkalmazott tervezési metodika, a formai kialakítás és a közigazgatási keretek különbözők, közös jellevonásuk a linearitás, a szabadterek megőrzése, valamint a kapcsolatteremtés a városi területek és a természetes, illetve a vidéki táj között.

Az első mintaterület az Ottawa körül létesített zöldöv, melynek tervezése a kanadai főváros átfogó városépítészeti tervezésének egyik legjelentősebb része volt. A terv 1950-re készült el, Jaques Greber francia városépítész irányításával. A tervnek - Ebenezer Howard kertváros koncepciójához hasonlóan - három fö célja volt:

- a további városi terjeszkedés megakadályozása és a (beépítésekkel) szomszédos mezőgazdasági területek megőrzése,

— tartalék építési területek biztosítása a kormány és közhasználatú intézményterületek számára,

— a fővárosi növekedés a "tényleges és gazdasági" határainak kijelölése.

A zöldöv kezdettől fogva sokféle tájhasználati lehetőséget nyújtott a lehatárolt területen belül. Domináltak a mezőgazdasági területek, az erdők és a természeti területek, kormányzati kutatóközpontok és repülőterek. Jelentős területet foglaltak el a szabadterek, az iskolák, a kórházak, a magánszektorhoz tartozó kutatóközpontok. A zöldöv ugyanakkor számos rekreációs használat számára nyújtott teret: létesültek többfunkciós kirándulóutak, lovasközpontok, kempingek, 
golfpályák, veteményeskertek. A zöldöv állami kijelölése problémákat is okozott: az állami hatáskört a helyi önkormányzatok és a helyi tulajdonosok nem fogadták el használat, az adózás és a beépíthetőség szabályozása miatt. Később a zöldöv egyes részterületei - a tulajdonviszonyoktól függően - a helyi önkormányzatok vagy magántulajdonosok hatáskörébe és ellenőrzése alá kerültek.

Az ottawai zöldöv magában foglalt XIX. századi városépítészeti alapelveket, amelyek a városi növekedés szabályozására és a városi terjeszkedés határainak meghatározására irányultak.

A másik három mintaterületen (Fish Creek és Meewasin térségei - folyó menti zöldutak, Toronto körüli biorégió) a természetes vízgyüjtő területek zöldútként való lehatárolása és használata nem jelentett problémát, mert azokon a területeken nem merült fel a városi terjeszkedés és a beépíthetőség kérdése.

A tervek végrehajtását tekintve a tanulmány megállapítja, hogy az első három terv (Ottawa, Fish Creek és Meewasin) a kormány közremüködésével ért el eredményeket, míg a torontó biorégió eredményességében a helyi szintü szervezetek irányításával lett eredményes. A torontói zöldút a helyi szintről, a helyi érdekeltek és a helyi önkormányzatok bevonásával létrejövő végrehajtás jó példája. A szövetségi kormány ebben az esetben katalizáló szerepet tölt be a források és a szakmai szakmai háttér biztosításával. A térségi önkormányzat biztosítja a forrásközpontot, az információs bázist, a közigazgatási és hatósági egyeztetési folyamatokat. Mindegyik esetben alapvetően fontos volt az összes érintett bevonása a tervezési folyamatba.

\subsubsection{Zöldutak Európában}

Az európai zöldutak tervezési hátterét a tájépítészeti publikációk és internetes források alapján mutatom be.

\section{Párizs-London zöldút}

A franciaországi zöldutakat nagyrészt felhagyott vasútvonalak nyomvonalán alakították ki. Az országos kerékpáros útvonalhálózathoz burkolat nélküli kerékpáros útvonalakként kapcsolódnak. Az angliai zöldutak fejlesztési lehetőségeivel Tom Turner tájépítész foglalkozik. Turner szintén az olmstedi modellt tekinti kiindulási alapnak, és a zöldutakhoz tartozónak tartja vízi utakat és a háztetők között kialakítható zöldutakat is. A Párizs-London zöldút a 2012-es olimpiai fejlesztések egyik fő attrakciója volt. Elsősorban kerékpáros használatú, amely a meglévő franciaországi és angliai zöldutak összekapcsolásával és kiegészítésével jött létre. 


\section{Krakkó-Prága-Bécs zöldút}

A három fővárost összekötő útvonal a Közép-európai Zöldutak Szövetségének útmutatói szerint, elsősorban civil szervezéssel létrejött zöldút, elsősorban meglévő, kerékpárral járható útvonalak összekapcsolásával. Az utak különfélék, jellemzően szilárd burkolat nélküliek, de biztonságosan használható, egyenletes felszínűek, minőségük változó. A térségi jelentőségű zöldúthoz magas színvonalú - szálláslehetőséget, kerékpárkölcsönzést, helyi programokat biztosító - turisztikai szolgáltató hálózatot építettek ki.

Az európai zöldutak áttekintése alapján egyértelmüen megállapítható, hogy azok rekreációs és ökológiai szereppel egyaránt rendelkeznek, tehát az amerikai zöldút-tervezés fejlődési folyamatához hasonlóan multifunkcionálisak.

\subsection{Zöldút-tervezési irányelvek és útmutatók}

\subsubsection{Amerikai zöldút-tervezési irányelvek}

Az amerikai zöldút-tervezés irányelveivel számos kézikönyv foglalkozik., melyek a többféle rekreációs használatú utak elhelyezésének variációit mutatják be. A gyalogos, a kerékpáros, és a lovas használatú utak elválasztását növénysávval vagy változatos tereprendezési megoldásokkal javasolják, térbeli lehetőségektől függően. A vízparti területek esetében a felszíni vizek minőségének helyreállítását és a természetközeli mederrendezések módjait a zöldút-tervezés feladatai közé sorolják (FLINCK AND SEARNS, 1993, HELLMUND AND SMITH, 2006).

\subsubsection{Európai zöldút-tervezési útmutatók}

\section{Angliai zöldút-tervezési kézikönyv}

Tervezők és hatóságok számára készült, legfőbb értéke vegyes forgalmú és az elválasztott rendszerü zöldutak keresztmetszeti méreteinek meghatározása a mért vagy a várható forgalom függvényében.

Az angliai zöldutak létesítését és müködtetését ösztönzi a helyi hatóságok számára készült Zöldutas kézikönyv. (GREENWAY HANDBOOK, 2002)

A kézikönyv célja az, hogy a közigazgatásban dolgozók ismereteinek bővítésével hozzájáruljon a motormentes közlekedési módok (gyaloglás, kerékpározás, lovaglás) lehetőségeinek növeléséhez. A meggyőzés fő eszköze az, hogy statisztikai mérésekkel és közvélemény kutatási eredményekkel megalapozott igények alapján felhívja a figyelmet a lehetséges megoldásokra, illetve ismerteti a zöldút fejlesztés céljából megalkotott tervezési irányelveket. 


\section{Az Európai Zöldutak Szövetségének ajánlásai}

Az Európai Zöldutak Szövetségének célja olyan civil programok támogatása, amelyek motormentes közlekedésre alkalmas útvonalak kijelöléséhez kapcsolódóan turisztikai fejlesztéseket segítenek elő, támogatják a helyi természeti és kulturális értékek megismertetését és védelmét, valamint a helyi termék készítők és szolgáltatók bekapcsolását a zöldutak használatához kapcsolható turisztikai szolgáltatások körébe. A szövetség által kidolgozott útvonal kijelölési szempontrendszer fő elemei városi és vidéki környezetben, rövidebb vagy hosszabb távolságú zöldutakra vonatkozóan egyaránt az adott táj értékeinek bemutatására és a turisztikai célú fejlesztésekre irányulnak. Az útvonalak többsége meglévő, használható út, amely motormentes közlekedésre alkalmas. A zöldút program újszerüsége különböző időtartamú (egy napos, hétvégi vagy több napos) biztonságosan használható kirándulási útvonal ajánlása és lehetőség szerinti fejlesztése.

A szövetség által javasolt fő útvonal kijelölésre és felszín kialakításra vonatkozó kritériumok:

— az útvonal a településközpontjain áthalad vagy a központ az útról könnyen elérhető;

— a zöldutak kiindulópontjai gyalogosan, kerékpárral vagy tömegközlekedéssel elérhetők;

— az útvonalak követik a rendelkezésre álló, régi vagy nem használt közlekedési útvonalakat;

— hosszútávú és városi zöldutak esetében a szilárd burkolatú felületek aránya minimum 90\%;

— városi zöldutak lejtése alacsony vagy $0 \%$.

Egyéb, sajátos turisztikai fejlesztést szolgáló kialakítási szempontok:

— zöldutakról szóló információs kiadvány a települési információs központokban,

- maximum 15 km-enként természeti, kulturális, turisztikai attrakció,

- kb. 20 km-ként pihenőhely,

— 30 km-ként szállás- és étkezési lehetőség,

- legalább egy információs tábla,

— legalább egy helyi terméket forgalmazó pont (üzlet, műhely, galéria),

- legalább egy helyi ételeket kínáló étterem, fogadó,

— legalább egy zöldúthoz kapcsolódó turisztikai termék elérhető legyen. (www.greenways.by)

\subsection{Az amerikai és az európai zöldút-tervezés modellértékü sajátosságai}

A zöldút-tervezés amerikai és európai előzményeinek, tudományos és gyakorlati eredményeinek tanulmányozása alapján a következőket állapítom meg: 
— a tájépítészeti szakirodalom a zöldút-tervezés alapgondolatának megjelenését Frederick Law Olmsted 'Emerald Necklace' elnevezésü tervéhez köti. Olmsted újítása a parksétányok szerepének áthelyezése egy folyó nyomvonalához illeszkedve, illetve egy alapvetően lineáris parkrendszer létrehozása a környező szabadterek bekapcsolásával;

— a zöldút fogalom először telekosztásokhoz kapcsolódóan, vízfolyások mentén létesíthető rekreációs szerepü övezetként jelent meg, helyi földtulajdonosok és az illetékes városi építési hivatal által kölcsönösen elfogadott megállapodás értelmében;

- a XX. századi nagyszabású közúti fejlesztések következtében felhagyottá vált vasúti nyomvonalakat társadalmi kezdeményezéssel rekreációs célú hasznosításra - többféle motormentes közlekedésre alkalmas kiránduló útvonallá - alakították át, melyeket később szintén zöldutaknak neveztek;

— a zöldút-tervezés megkezdésének és elterjedésének katalizátora a kedvezőtlen városépítészeti és a környezetvédelmi jelenségek csökkentése érdekében elnöki határozattal és állami támogatással kezdeményezett szabadtér-fejlesztési program volt;

— a szakirodalom az amerikai zöldutakat szerepük szerint alapvetően három típusba sorolja: ökológiai, rekreációs, kulturális zöldutak;

— az amerikai zöldút-tervezésre irányuló kutató és oktatói munkájának célja a helyi szinten létesített zöldutak térségi és országos szintü összehangolása, a rekreációs használat és az ökológiai szempontok összeegyeztetése, és térségi szintü zöldút-hálózat koncepciójának volt;

— Európában az ökológiai szerepű lineáris zöldfelületek ökológiai- és zöldfolyosó elnevezésekkel szerepelnek az ökológiai szakirodalomban;

— Európában - és így Magyarországon is - a zöldutak amerikai típusai közül a rekreációs szerepü ökológiai - és zöldfolyosók helyi, térségi és országos szinten összehangolt tervezése jelenthet újszerü, új igényeket kielégítő tájépítészeti feladatot.

Searns kiemeli, hogy a multifunkcionális zöldutak tervezéséhez és létesítéséhez szakterületek mérnöki, tájépítészeti, ökológiai - együttmüködése, és a különféle szakterületi szempontok összehangolása szükséges. 


\section{A MODELL MAGYARORSZÁGI ALKALMAZHATÓSÁGA}

A zöldút-tervezés nemzetközi szakirodalmának áttekintése alapján megállapítottam, hogy a zöldúttervezés tájépítészeti szempontú kiindulási alapja a Frederick Law Olmsted 'Emerald Necklace' tervében megnyilvánuló újszerü városépítészeti gondolat táji léptékü kiterjesztése. Az olmstedi tervezési gondolatot az amerikai és az európai tájépítészeti szakirodalom - széleskörü szakmai egyetértéssel - a zöldút-tervezés modelljeként határozza meg. Azokban az európai országokban, ahol a zöldút-tervezés tájépítészeti kibontakozása észlelhető (Anglia, Hollandia, Portugália, Olaszország), a tájépítészeti kutatások és a tervezési gyakorlat az olmstedi modell elfogadására és annak - az egyes országok sajátos táji adottságainak és tervezési környezetének figyelembevételével történő - alkalmazására épül. Értekezésem megalapozásaként ezért meghatároztam az olmstedi zöldút modell magyarországi alkalmazhatóságának alapvető kérdéseit és a kérdések megválaszolásához vezető vizsgálati szempontokat (4. ábra)

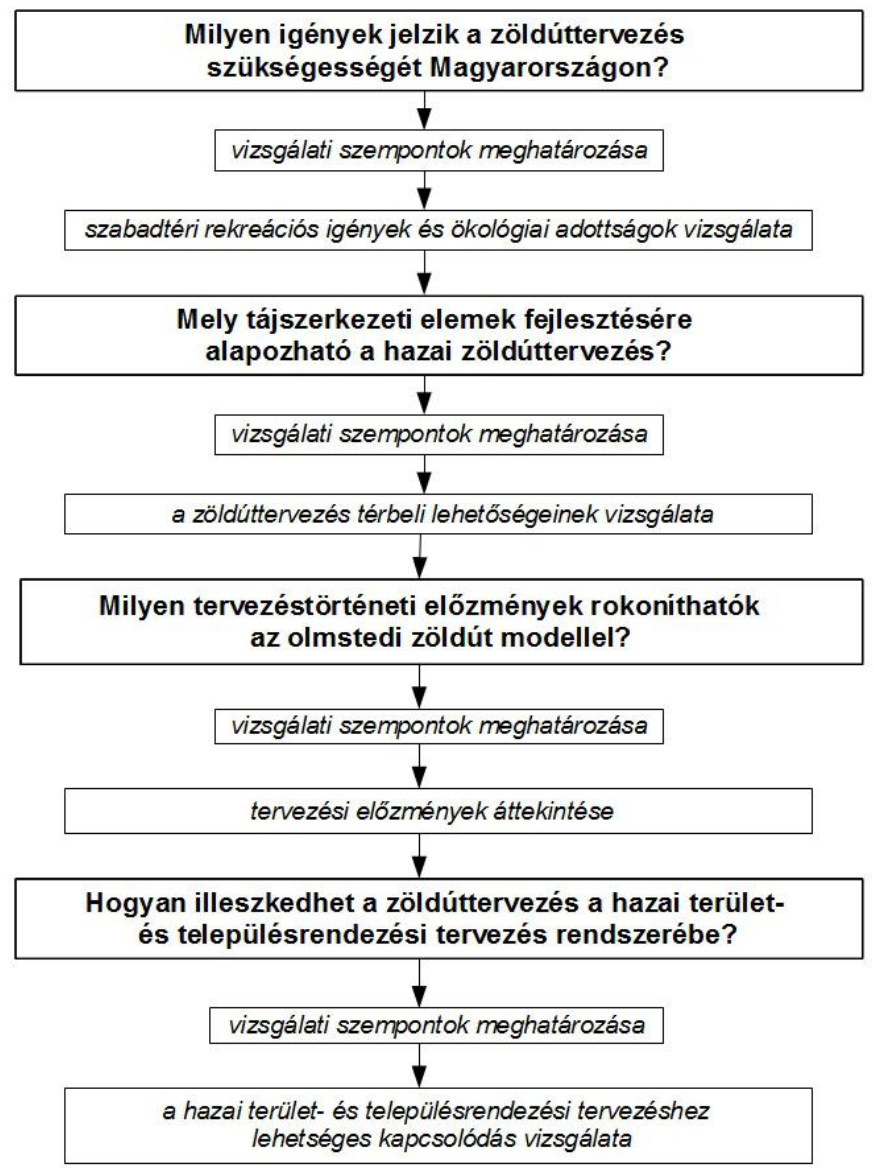

4. ábra: A zöldút modell hazai alkalmazhatóságának vizsgálati szempontjai (saját szerkesztés) 
Milyen igények jelzik a zöldút-tervezés szükségességét Magyarországon?

A zöldút-tervezés modellje alapján a zöldút-tervezés alapvető célja olyan szabadtéri rekreációs lehetöségek térbeli biztosítása, amelyek természetes vagy természetközeli területekhez kötődnek. Ebböl következik, hogy a zöldút-tervezés szükségességét egyrészt rekreációs, másrészt ökológiai igények jelentkezése jelzi.

Vizsgálati szempontok:

— meglévő és tervezett szabadtéri rekreációs lehetőségek

— jelentkező rekreációs igények

— ökológiai állapot

— ökológiai fejlesztési feladatok

Mely hazai tájszerkezeti adottságokra alapozható a zöldút-tervezés?

A zöldutak létesítésének klasszikus területei folyóvizek partjai, felhagyott vasútvonalak területei, történelmi útvonalak és egyéb sajátos nyomvonalak, amelyek többféle rekreációs használat számára alkalmasak.

Vizsgálati szempontok

— folyók, patakok, vízfelületek és környezetük rekreációs hasznosíthatósága

— felhagyott vasúti nyomvonalak rekreációs hasznosíthatósága

— történelmi útvonalak rekreációs hasznosíthatósága

— egyéb természetes vagy természetközeli nyomvonalak rekreációs hasznosíthatósága

Milyen tervezéstörténeti elözmények rokonithatók az olmstedi zöldút modellel?

A tájépítészeti szakirodalom Olmsted 'Emerald Necklace' tervében megjelenő tájépítészeti gondolatot és annak táji léptékü kiterjesztését tekinti a zöldút-tervezés modelljének. Olmsted modellértékủ tervének is voltak előzményei: az európai nagyvárosok fásított bulvárai, az amerikai nagyvárosok parksétányai. Ezért Olmsted tervezői újítása nem csak önmagában, hanem a tervezéstörténeti elözményekhez és a már kialakult városszerkezethez való illeszkedés miatt különösen értékes. A magyarországi zöldút-tervezés megalapozása, illetve gyakorlati megvalósítása érdekében célszerủ a hazai tervezéstörténeti előzményeket feltárni.

Vizsgálati szempontok

- konkrét hazai zöldfelülettervezési példák kiválasztása, amelyek természetes vagy természetközeli környezetben nyújtottak/nyújtanak séta, kerékpározás, lovaglás számára lehetöséget 
— a hazai gyalogos, kerékpáros és lovas kirándulási lehetőségek áttekintése

Hogyan illeszkedhet a zöldút-tervezés a hazai terület- és településrendezési tervezés rendszerébe?

A hazai tájtervezés müszaki-jogi szempontból a területrendezési és a településrendezési tervezésbe integrálódott, ezért a területi vonatkozású tájrendezési célú javaslatoknak a területrendezési és a településrendezési tervezés rendszerébe kell épülniük (SCHUCHMANN, 2007, GERZÁNICS, 2013). Ennek értelmében a tájépítészeti javaslatok akkor válhatnak a hazai jogrend részévé - vagyis a gyakorlat számára megvalósíthatóvá -, ha azok beilleszthetők a terület- és településrendezési tervezés rendszerébe.

Vizsgálati szempontok

— a terület- és a településrendezési tervezés olyan tervezési eszközeinek kiválasztása, amelyek alkalmazásával a zöldút-tervezés integrálható a terület- és a településrendezési tervezés rendszerébe,

— a javasolt terület- és településrendezési eszközök alkalmazhatóságának igazolása konkrét példákkal a mintaterületen

\subsection{Tervezéstörténeti előzmények}

\subsubsection{Városi sétányok}

A XIX. századi Pest-Buda nagyvárossá alakítása az akkori európai nagyvárosok fejlődésével párhuzamosan haladt, és a várost tagoló zöldfelületi elemek kialakítása is megkezdődött. A városi környezet egészségesebbé tételének szükségességére elsőként gróf Széchenyi István hívta fel a figyelmet. "Pesti por és sár" címü írásában az angliai városok példájára fasorok ültetését, sétányok és közparkok építését sürgette, és megvalósításukat tevékenyen támogatta (SZILÁGYI, 2003).

A XIX. századi városi sétányok közül kiemelkedik a ma már világörökségként védett Andrássy út. Az egykori Sugárút elegáns bulvárrá alakítása Andrássy Gyula miniszterelnök kezdeményezésérére valósult meg. Célja a belváros és a Városliget összekötése volt, az akkori külvárosias területek fejlesztésével, a párizsi Champs Elysées és a bécsi Ring példájára. Jellemző részlet, hogy az elképzelés megvalósítását az akkori fővárosi képviselőház többsége kezdetben túlzó költekezést jelentő luxus építkezésnek tartotta. Építése azonban 1885-re teljesen befejeződött, Lechner Lajos tervei szerint: az út két szélén egy-egy sétaút, középen háromsávos kocsiút, fasorokkal elválasztott rendszerben, a beépítés fokozatos fellazításával.

\subsubsection{Kastélyok környezete}

A parksétányok beépített területeken túl vezető változatainak XIX. századi példái a barokk 
kastélyokból vagy a települések központjából induló, fasorokkal kísért sétautak, lovaglóutak, lovaskocsi utak és szekérutak, melyek gyakran nagyvonalú tájépítészeti alkotásként jelentek meg a tájban. Egy részük ma is ugyanolyan értékes, meghatározó tájelem, amely tájképi vagy természetvédelmi védettséget élvez, más részük viszont elbozótosodott, elvadult állapotban van, vagy éppenséggel eltünt a megváltozott tájhasználat okán. A séta- és lovaglóutak egy része főúri használatot szolgált, más részük már építésük idején közhasználatú volt. A tájban betöltött közös szerepük a hangsúlyozni kívánt tájelemek közötti funkcionális, vizuális és ökológiai kapcsolat megteremtése.

\subsubsection{Gyalogos, kerékpáros és lovas útvonalak}

\section{Gyalogos turistaútvonalak}

Magyarországon a gyalogos természetjárásnak évszázados hagyománya van. Az iparosodás és a polgárosodás korában kialakult a szervezett természetjárás is. A Magyar Kárpát Egyesület irányításával 1873-ban megkezdődött a túraútvonalak, menedékházak, kilátók és egyéb turistalétesítmények építése a Tátrában, majd 1929-ben egységes országos útjelzési rendszert is bevezettek. 1938-ban kijelölték az egész országon átvezető Országos Kéktúra hálózatát, amely ma is közkedvelt.

A turistautak közérdekből turisztikai célú gyalogos közlekedés (gyalogtúrázás) céljából létesített vagy e célra (is) ajánlott útvonalak. A turistautak kijelölésének rendjéről szóló 2009. évi XXVII. törvény az erdőről, az erdő védelméről és az erdőgazdálkodásról szerint a turistautak kijelölését az érintettekkel egyeztetni szükséges. A turistaút bel- és külterületen, köz- és magánterületen, mezőgazdasági és erdőterületen, bármilyen más úttípussal egy nyomvonalon (kivéve autópálya, autóút) vezethet. A turista útvonalakat a törvény végrehajtására kiadott jogszabály szerint, jól látható jelzéssel kell megjelölni és nyilván kell tartani. Az Erdőtörvény szerint az erdőben az erdőben - annak rendeltetésétől függetlenül - üdülés, sportolás és kirándulás céljából bárki saját felelősségére ott tartózkodhat. A turistaútvonalak jelzései tehát az erdei kirándulás biztonságát, a pontos tájékozódást segítik (MOLNÁR, 2014).

A kirándulás, mint rekreációs tevékenység iránt jelentkező fokozódó igény hatására a hagyományos turistautak mellett megjelentek az úgynevezett tematikus útvonalak is, melyek sok esetben a kijelölt turistautak nyomvonalán, ahhoz kapcsolódva jelentenek valamilyen speciális szempont szerinti útvonaljavaslatot. A "Turistaúthálózat és jelzésrendszer" című szakmai kiadványban a szerzők ezeket az útvonalakat így csoportosítják:

— kulturális és turisztikai tematikus útvonalak (pl. Móricz Zsigmond turistaút, Mátraaljai borutak, Szent Márton vándorút, Szent Erzsébet vándorút stb.), 
— zarándokutak (pl. Mária út, Szent Jakab út, Gyöngyök útja, Magyar Zarándokút stb.),

— civil zöldutak.

A szakmai kiadványban szereplö "civil zöldút" definíció meghatározza a civil zöldutak fő célját és szerepét a rekreációs szerepű útvonalak között: "A zöldutak közösségi kezdeményezésű helyi jellegü útvonalak, úthálózatok, nem mindig, illetve nem kizárólag gyalogos jármód számára. Céljuk a szemléletformálás, a közösségépítés, a helyi "zöld" közlekedés elősegítése, a kapcsolódó helyi értékekre, olykor termékekre való figyelem felhívása. Ezek a Zöldutak Módszertani Egyesület (ZÖME) által koordinált útvonalak" (MOLNÁR, 2014).

\section{Turisztikai célú kerékpáros útvonalak}

Az első kerékpár 1878-ban jelent meg Magyarországon, az első társas kerékpáros kirándulást pedig 1881. Húsvétján szervezték a budapesti Városliget és Gödöllő között, mintegy 30 km-es távon. 1911-től a Magyar Kerékpáros Szövetség vasárnaponként országúti és pályaversenyeket szervezett. A magyar kerékpárosok először 1912-ben vettek részt olimpián, 1925-ben világbajnokságon. 1928tól 1965-ig (majd 1993-tól újra) évente megrendezik a Tour de Hongrie körversenyt. A II. világháború után a kerékpár szerepe a sport és a szórakozás helyett egyre inkább a közlekedés lett. Az 1980-as évek végétől egyre népszerübb lett a kerékpáros turizmus. Számos térkép és könyv jelent meg a kerékpározásról és a kerékpározási lehetőségekröl. (TöRÖK, 2002)

Az 1990-es évektől kezdődően a kerékpáros turizmus iránti igény tovább nőtt, és az uniós pályázati lehetőségek lehetőséget nyújtottak új kerékpárutak tervezésére és építésére - elsősorban az országos közutak mentén. Az országos és a térségi kerékpáros útvonalak meglévő és tervezett nyomvonalai megjelentek a területrendezési tervek müszaki infrastruktúra hálózati munkarészeiben.

A kerékpárutak tervezése során megkülönböztetnek közlekedési célú és szabadidős célú kerékpározást. A kerékpáros tervezési lehetőségek bővültek, a 2010. április 15-től érvényes új e-UT 03.04.11 Útügyi Műszaki elöírás alapfogalomként a kerékpáros forgalmi létesítményeket nevez meg, és azokat alapvetően három csoportba sorolja:

— önálló kerékpárforgalmi létesítmények (ide tartoznak: kerékpársáv, közút melletti kétirányú kerékpárút, közút melletti kétoldali egyirányú kerékpárút, elválasztott gyalog- és kerékpárút, elválasztás nélküli gyalog- és kerékpárút),

— az útpálya felületén burkolati jellel jelölt kerékpárforgalmi létesítmények (ide tartoznak: kerékpáros nyom, nyitott kerékpársáv),

— nem önálló kialakítású, de kerékpározás céljára igénybe vehető vegyes forgalmú felületek (ide tartoznak: széles forgalmi sáv, autóbusz forgalmi sáv, csillapított forgalmú terület, egyirányú forgalmi utca, részlegesen vagy teljesen burkolt útpadka, kis forgalmú utca, párhuzamos 
szervizút, árvízvédelmi töltés, erdészeti üzemi út, mezőgazdasági út).

A két legjelentősebb, országos szintű folyó menti fejlesztés a Duna menti kerékpárút építése lehetőségek szerint a Duna jobb vagy bal partján a Duna projekthez kapcsolódóan és a Tisza -menti kerékpárút fejlesztés a Tisza-projekthez kapcsolódóan a Tisza mindkét partján. Ezen útvonalak a nemzetközi EuroVelo úthálózat részei is egyben. A fejlesztések a területileg illetékes vízügyi igazgatóságok irányításával történnek.

\section{Lovastúra útvonalak}

A ló és a lovaglás alapvető szerepet töltött be a magyarság történetében a honfoglalás kori kalandozó hadjáratoktól a lótenyésztés XIX. századi aranykorán át a huszárság, mint fegyvernem kialakulásáig. A második világháború után a lótenyésztés minimálisra esett vissza. 1990 óta a lovaglási hagyományok feléledtek. A Kárpát-medence kedvező természeti adottságai, domborzati, vízrajzi és időjárási viszonyai különösen kedvezőek lótartás és lovaglás számára. Jelenleg folyik a Kincsem Nemzeti Lovasprogram kialakítása, amelynek fő célja az egész országot átszövő lovastúra útvonalak kijelölése. A meglévő és tervezett gyalogos, kerékpáros, lovas útvonalak összehangolása céljából jelenleg készül a Bejárható Magyarország program.

\subsubsection{Civil zöldutak}

2005 óta az Ökotárs Alapítvány kezdeményezésére alakultak zöldutak Magyarországon, az Európai Zöldutak programjának iránymutatásaira alapozva. A civil keretek között szerveződő zöldutak létrehozásának fő célja meglévő nemmotoros használatra alkalmas útvonalak kijelölése zöldútként, majd ehhez kapcsolódóan az adott térségekben a turisztikai vonzerő növelése.(www.zome.hu)

Eddig megkezdett civil zöldutak az általuk érintett térségekkel:

- Duna-Ipoly Zöldút (Vác és Szob térsége),

- Örökségeink Útján Zöldút (Cserhát),

- Budavidék Zöldút (Zsámbéki-medence),

— Föld Szíve Pilisi Zöldút (Pilis hegység),

— Vasfüggöny Zöldút (nyugati országhatár),

- Tanya-kör Zöldút (Kiskunmajsa környéke),

- Mecseki Zöldút (Mecsek).

\subsubsection{Az egészséges életmód Magyarország politikai jövőképében}

Magyarország politikai jövőképét a jogrendszer alapjának tekinthető Alaptörvény határozza meg. 
Az Alaptörvény azt az alapvető emberi jogot, hogy "Mindenkinek joga van a testi és lelki egészséghez" (Alaptörvény, XX. cikk), több rendelkezésben, bővebben kifejti, és mindezt átfogó, a fenntartható fejlődés eredeti értelmében vett elvének idézésével is hangsúlyozza: „Vállaljuk, hogy örökségünket, (...) a Kárpát-medence természet adta és ember alkotta értékeit ápoljuk és megóvjuk. Felelősséget viselünk utódainkért, ezért anyagi, szellemi és természeti erőforrásaink gondos használatával védelmezzük az utánunk jövő nemzedékek életfeltételeit.”

Az Alaptörvény környezetvédelmi és fenntarthatósági rendelkezéseivel kapcsolatban Fülöp Sándor, a Jövő Nemzedékek Országgyülési Biztosaként állásfoglalást adott ki, amelyben kiemeli:

"Az Alaptörvény elöremutató azokban a rendelkezésekben is, amelyek az emberek számára biztosítják az egészséges életmód feltételeit. Az élelmezés és az egészség, a mozgás és az egészség, általában a környezet és az egészség összekapcsolása az alaptörvény szintjén megerősíti a rendszerszemlélet és a rendszerben való kezelés szükségességét" (FÜLÖP, 2011).

A Biztos állásfoglalásában felhívja a figyelmet arra, hogy "Az új alkotmányos rendelkezések alapján most kell gondoskodni arról, hogy az Alaptörvény egészséges környezethez való joggal és a jövő nemzedékek érdekeinek védelmével kapcsolatos iránymutatásai szervesen beépüljenek a másodlagos joganyagba, az állami intézményrendszer eszközei és keretei ennek megfelelően bővüljenek, javuljanak, s így összességében megtörténjék a tényleges elörelépés. Az Alaptörvényből egyenesen következik elsődlegesen a hazai természetvédelmi, vízvédelmi, környezetvédelmi, talajvédelmi, építésügyi és közegészségügyi hatósági intézményrendszer megerősítésének, valamint a munkájukat támogató tudományos monitoring és alapkutatás biztosításának kötelezettsége is." (FÜLÖP, 2011, P.4.).

Az Alaptörvényben egyértelműen megfogalmazott elvekhez kapcsolódó tájépítészeti feladat az egészséges életmódra és a fenntarthatóságra vonatkozó elvek térbeli megvalósításához szükséges szakmai háttér megteremtése a tervezés minden szintjén, a területrendezési tervezéstől az objektumtervezésig - a zöldút-tervezés lehetőségére vonatkozóan is.

\subsection{Táji adottságok vizsgálata a zöldút modell alkalmazhatósága szempontjából}

\subsubsection{Vízrajzi adottságok}

\section{Vizfolyások és tavak környezete}

Magyarország két fő folyója a Duna és a Tisza. Mindkét folyónak vannak természetközeli és településekkel beépült szakaszai egyaránt. A Duna környezete része a Nemzeti Ökológiai Hálózatnak és a Páneurópai Duna-menti Ökológiai Hálózatnak is. A Duna menti ártéri ligeterdők különösen nagy ökológiai értéket képviselnek. A Duna átfolyik Magyarország fővárosán, 
Budapesten és több nagyvárosunkon is: Komáromon, Győrön, Esztergomon, Vácon, Százhalombattán, Dunaújvároson, Pakson, Mohácson. Több Duna-parti településen alakítottak ki gyalogos sétányokat vagy kerékpárutakat egy-egy szakaszon. Ezek a sétányok, kerékpárutak azonban szakaszosan jelennek meg, és jellemzően egy-egy funkciót szolgálnak. Néhány helyen megjelenik egymás mellett a gyalogos és a kerékpáros funkció, több esetben a lovaglás is. A kialakítás egyes esetekben tervek alapján, egyes helyeken a meglévő lehetőségek spontán használatba vételével történt meg. Összefüggő útvonal kialakításának tervét jelenti a Duna és a Tisza magyarországi szakaszai mentén tervezett EuroVelo kerékpáros útvonalak kijelölése, meglévő és tervezett kerékpáros útvonalak összekapcsolásával. Az EuroVelo útvonalak az amerikai zöldutakhoz hasonló alapokon nyugvó civil kezdeményezésnek tekinthetők, a meglévő adottságok alapján és helyi kezdeményezéssel alakítanak ki kerékpározásra alkalmas szakaszokat. Komplex tervezésükre és megvalósításukra uniós források egyelőre nem állnak rendelkezésre. Az Országos Területfejlesztési Koncepció a Duna mentét kiemelt térségként határozza meg. A Duna menti multifunkcionális folyómenti tér turizmusra fókuszáló fejlesztésének alapja a VÁTI-ban 2008-ban készült "A Duna menti turizmus hazai és nemzetközi dimenziói" címü koncepció.

A mellékfolyók közül elsőként a Rába menti töltésen merült fel kerékpáros útvonal kialakításának lehetősége, a Rába ausztriai szakaszán kiépített kerékpáros útvonalak folytatása képpen. A töltéseken gyalogos útvonalak kialakítása nem merült fel, mert a töltések teteje jellemzően fátlan, árnyékmentes terület, így hosszan tartó gyaloglásra kellemetlen környezetet jelentenének.

A kisebb patakok ideális lehetőséget jelentenek zöldutak kialakítására. Problémát egyrészt a patakok vízépítési szempontok szerint kialakított, tájidegen mederkialakítása, másrészt a vízépítési szempontú patakmeder karbantartás miatt fátlan környezet jelentik. A patakok jelentős része a Nemzeti Ökológiai Hálózat része. Ökológiai folyosóként a növényzettel kísért sáv szélességének és diverzitásának vizsgálata után állapítható meg a rekreációs hasznosítás lehetősége. A patakok menti zöldút fejlesztést célszerü összekötni a patak revitalizáció tervezésével.

\subsubsection{A magyarországi vasúthálózat}

Az első magyarországi vasútvonalat 1846. július 15-én nyitották meg Pest és Vác között. A vasúti hálózat az első világháború kitöréséig folyamatosan fejlődött. A XX. század fordulójáig több ezer kilométer helyiérdekü vasútvonal épült Magyarország akkori területén. Történelmi vagy gazdasági okokból azonban többször került sor vasútvonalak részleges vagy teljes bezárására. Az első vonalbezárásokra az első világháborút követően került sor, a trianoni országhatárok által elvágott zsákvonalakon. A második vonalbezárási hullám a második világháborút követően, a 
közúti közlekedés fejlesztése következtében történt. Az 1960-as években a vasút villamosítása is elkezdődött, amelynek során a szükséges helyeken nyomvonal-korrekciókat végeztek, és így rövidebb-hosszabb felhagyott vonalszakaszok keletkeztek.

A legnagyobb vasútvonal bezárásokra az 1968-as közlekedési koncepció alapján került sor: 1200 km normál nyomközü, kis forgalmú vasútvonal és az összes keskeny nyomközü gazdasági vasút felszámolása történt meg. Az 1990-es években Magyarországon is elindult a motorizáció ugrásszerű fejlődése, ezért a közúti személy- és teherszállítás sok esetben kényelmesebb megoldást jelentett a vasúti közlekedésnél. A lakosság körében rohamosan megnövekedett a személyautók száma, és ez a tömegközlekedés igénybevételének csökkenését is eredményezte. Az A XX. század végén kialakult egyre nehezebb gazdasági helyzet miatt a szükséges fejlesztések elmaradtak, és újabb vonalbezárási hullám indult. Az 1990-es évek első felében 3, majd 2009.decemberében 24 vonalon szünt meg a személyszállítás. A vasútvonalak újraindítása mellett azonban számos érv sorolható. Egy Ipoly menti vasútvonal megtartását szolgáló tanulmányt az Eurorégiós térségi vasutak kezdeményezésére sikeresen újraindított német vasútvonalak példáival támasztottak alá.

A XXI. századra kialakult óriási környezetszennyezés mértéke miatt egyre meghatározóbb szempont az egyes közlekedési módok környezetre gyakorolt hatása is. A vasúti közlekedés környezeti szempontból talán az egyik legkedvezőbb az energiafelhasználás, a károsanyagkibocsátás, a területigény és a szállítási kapacitás szempontjából is. A vasúti pálya fenntartásában a kötelező fix költségek (pályafenntartás, infrastruktúra fenntartása) aránya nagyon magas, majdnem teljesen független a pályán zajló forgalomtól. A vasúti pályák a nemzeti vagyon részét képezik, ezért a vasútvonalak megszüntetése bonyolult jogi eljárást jelentő feladat.

A különböző időszakokban megszüntetett vasútvonalak nyomvonalai különböző állapotban vannak. Van olyan vonal, ahol személyforgalom nem, de teherforgalom még zajlik. Van olyan szakasz, ahol a síneket felszedték, így a közlekedés lehetetlen. Egyes szakaszokon csak az egykori vasúti töltés azonosítható. Ugyanakkor régi vasúti hidak, megállóhelyek megmaradtak, bár folyamatosan romló állapotban vannak. Vannak olyan szakaszok, ahol a felhagyott nyomvonalon elkerülő utat építettek. Végül van néhány példa, ahol a felhagyott nyomvonalon kerékpárutat építettek (pl. Veszprém-Alsóörs, Dombóvár-Tamási, Zalalövő-Bagod, Felsőtárkány-Felnémet).

Felmerül a kérdés: Lehetséges-e zöldutak létesítése Magyarországon felhagyott vasúti nyomvonalak mentén? A zöldút létesítés mellett az egyik jelentős érv, hogy a vasútvonalak nyomvonalai kis esésűek, amelyek gyaloglásra és kerékpározásra különösen kedvező lehetőséget nyújthatnak. Másrészt, a vasutak térigénye kiválóan megfelelő lenne többfunkciós rekreációs használat számára. Harmadrészt, a vasúti pálya alaptest már kis felújítással és megfelelő karbantartással megfelelő burkolatot jelenthet zöldutak számára. Az előzőekben elmondottak szerint 
a meglévő és a felhagyottá vált vasúti nyomvonalakat egyaránt jelentős közlekedési lehetőségnek kell tekinteni a jövőre nézve.

A megfelelő választ minden esetben egy adott terület földrajzi adottságai, társadalmi és gazdasági igényeinek és lehetőségeinek megfelelően lehet megadni. Általánosságban megállapítható, hogy a nyomvonal korszerüsítések során felhagyottá vált szakaszokon a leginkább elképzelhető a zöldút fejlesztés. Egyéb, egyelőre használaton kívüli szakaszokon olyan müszaki megoldásokkal lehetséges zöldutat kialakítani, hogy a vasúti közlekedés a jövőben szükség szerint visszaállítható legyen (CSEMEZ-KAPOVITS, 2013).

\subsubsection{Történelmi és kereskedelmi útvonalak}

Magyarország településeiről és az azokat összekötő útrendszerekről gazdag információanyagot tartalmazó térképek készültek a XVII-XIX. században készített katonai felmérések során.

A felméréseken jól láthatók azok a fő kereskedelmi útvonalak és kisebb forgalmú szekérutak, amelyek lovaskocsikkal, kocsikkal jól járhatók voltak, ezért évszázadokon át jól bevált útkapcsolatot jelentettek. Ezek egy része a későbbi századok során az egyre fejlődő közúthálózat elemeivé vált. Más részük jelenleg elsősorban a mező- és erdőgazdálkodást szolgáló földútként jelenik meg.

A történelmi útvonalakra optimális távolságot és szintesést jelentő racionális nyomvonalvezetés jellemző, ezért ezek az útvonalak alkalmasak lehetnek gyalogos- és kerékpáros közlekedésre is. Egyes területeken meg is figyelhető ezen utak spontán használatbavétele, illetve kerékpáros útvonalak felfedezésére irányuló helyi kezdeményezésű bejárások során sok esetben a történelmi útvonalakat javasolják kerékpáros útvonalak kijelölésére. Ezért ezek az útvonalak értékes elemei lehetnek egy adott táj különféle rekreációs szerepű nemmotoros forgalma számára. A feladat minden esetben az, hogy a rekreációs használatot össze kell egyeztetni a meglévő tájhasználati formákkal, és az útvonalak további használhatósága érdekében integrálni kell a területrendezési és és a településrendezési tervekbe.

Sok esetben a történelmi nyomvonalak egyes szakaszai gyaloglás, kerékpározás és lovaglás számára egyaránt a legkedvezőbb útvonalat jelentik. Kis forgalom esetén ez nem jelent gondot, azonban nagyobb forgalom esetén felmerül ezeken a szakaszokon a többfunkciós használat számára alkalmas zöldutak létesítése. Optimális megoldásokhoz a fásítást is magában foglaló megfelelő szabályozási szélességre van szükség.

A történelmi útvonalak menti zöldút-fejlesztés jól kapcsolódhat a mezőgazdasági szempontból egyaránt szükséges tájfásításokhoz és útfelszín-javítási feladatokhoz. A hiányzó mezővédő fasorok és erdősávok pótlását célszerü a tervezhető zöldút-hálózatok figyelembevételével megvalósítani. 


\section{A ZÖLDÚT MODELL ALKALMAZÁSA A ZSÁMBÉKI-MEDENCE TERÜLETÉN}

Kutatási mintaterületem a Zsámbéki-medence, amelynek zöldút-tervezési szempontból történő elemzése kutatói munkám megkezdésének oka volt. A Zsámbéki-medencében helyi társadalmi kezdeményezéssel kijelölt Budavidék Zöldút meglévő, gyalogosan és kerékpárral járható utak kiválasztásával és összekapcsolásával jött létre, a szabadidős kerékpározás iránt jelentkező egyre nagyobb igény kielégítésére. ${ }^{2}$ A civil zöldút-hálózat tájépítészeti lehetőségeit és a szükséges feladatokat érzékelve kezdtem meg kutatásomat. Az egyetemi oktatói munkához kapcsolódva külső konzulensként vettem részt a kijelölt úthálózat tájépítészeti értékelésére és a fejlesztési lehetőségekre irányuló hallgatói gyakorlatokon. ${ }^{3}$ A zöldút-tervezés tájépítészeti szakirodalmának tanulmányozása alapján a zöldút-hálózat további fejlesztési lehetőségeit, illetve a nemzetközi szakirodalomban elfogadott olmstedi zöldút modell értelmezésén alapuló tájépítészeti koncepcióját fogalmaztam meg azzal a céllal, hogy a mintaterületre vonatkozó javaslatokkal megalapozzam a magyarországi zöldút-tervezés tájépítészeti metodikáját, és ezzel hozzájáruljak a zöldút-tervezés hazai gyakorlati alkalmazásához. ${ }^{4}$

\subsection{Térségi adottságok}

\subsubsection{Területi lehatárolás}

A Zsámbéki-medence a Békás-patak felső vízgyüjtő területe által meghatározott természetföldrajzi táj. A táj belső részét képező hullámos felszínű medencesíkságot a Budai-hegység, a Gerecse és az Etyeki-dombság 4-500 m magas vonulatai veszik körbe. A települések a medence peremén helyezkednek el.

Az MTA földrajzi tájbeosztása szerint a Zsámbéki-medence, mint kistáj a Bicske-Zsámbéki medence kistájcsoporthoz, a Dunazug hegyvidék középtájhoz és a Dunántúli dombvidék nagytájhoz

2 A Zsámbéki-medencében civil keretek között kijelölt zöldút hálózat egyik kezdeményezöje, kezdetben koordinátora, majd a zöldút program megvalósítása céljából helyi magánszemélyek és települési önkormányzatok részvételével megalakított Budavidék Zöldút Szövetség elnöke voltam.

3 Külső konzulensként vettem részt a következő hallgatói feladatok kiírásában és kidolgozásában:

"Kerékpáros útvonalak tájépítészeti tervezése a helyi társadalom részvételével a Zsámbéki-medencében" (BCE

Tájtervezési és Területfejlesztési Tanszék, Tájtervezés 2., 2008-2009)

"Dél-Budakörnyéki zöldút tájépítészeti tervezése" (BCE Tájtervezési és Területfejlesztési Tanszék, Komplex tájtervezés, 2009-2010)

"Mezögazdasági földutak környezetének tájépítészeti feladatai Tök közigazgatási területén a Budavidék Zöldút fejlesztéséhez kapcsolódóan ((BCE Tájtervezési és Területfejlesztési Tanszék, Komplex tájtervezés, 2010)

"Biatorbágy, zöldút terve" (BCE Kert- és Szabadtér Tervezési Tanszék, Zöldfelületi rendszerek, 2012)

4 Kutatásom egyes lépéseinek eredményeit az Irodalomjegyzékben önálló csoportban feltüntetett saját publikációim tartalmazzák. 
tartozik. A mintaterület lehatárolását a Zsámbéki-medencéhez tartozó települések - Zsámbék, Tök, Perbál, Tinnye, Budajenő, Telki, Páty, Biatorbágy, Herceghalom - közigazgatási határai alapján tettem meg. Közigazgatási szempontból e települések Pest megyéhez és - Tinnye kivételével - a Budakeszi járáshoz tartoznak. Területrendezési szempontból a teljes mintaterület a Budapesti Agglomeráció, mint kiemelt térség nyugati szektorához tartozik (5.ábra)
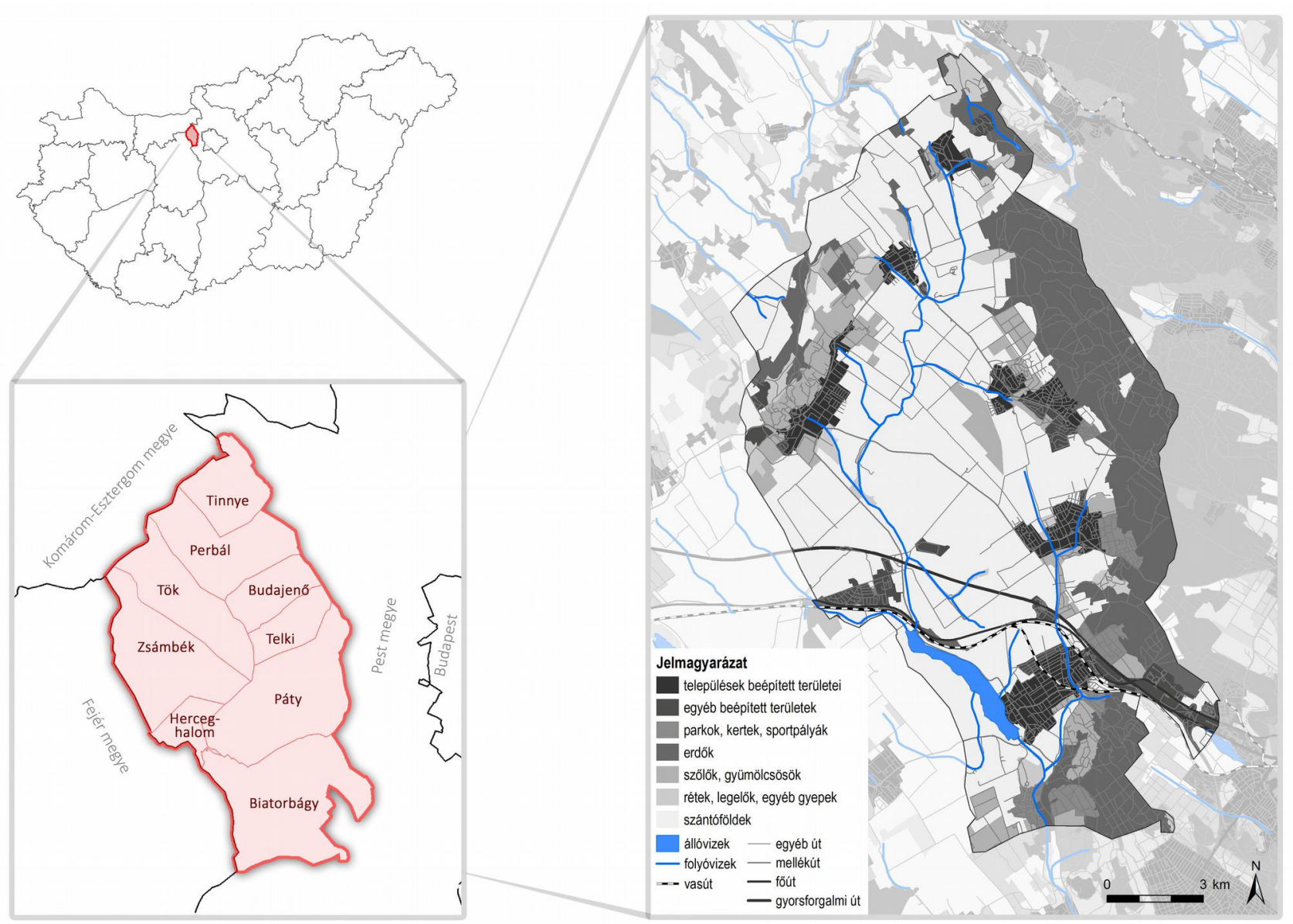

5. ábra: A Zsámbéki-medence térségi elhelyezkedése és áttekintő térképe (saját szerkesztés)

\subsubsection{Természeti adottságok}

A Zsámbéki-medence a Gerecse és a Budai-hegység között formálódott tektonikus medence. ÉNyDK-i és erre merőleges Ny-K-i irányú szerkezeti vonalak mentén medencealapzata közel $1000 \mathrm{~m}$ mélyre süllyedt. A medencét a Gerecse és a Budai-hegység mezozóos dolomit és mészkő formációiból, ill. szarmata mészkőből épült sasbércek keretezik. Felszínépítő alapkőzetek a mészkő, az agyag, a lösz, a lejtöüledék, a kavics és az édesvízi mészkő. A kialakult talajféleségek közül a medence belsejében jellemzők a löszön képződött jó termékenységü mészlepedékes csernozjom talajok. A magasabb felszíneken közepes termékenységü barnaföldek és rendzina talajok fordulnak 
elő. A jó minőségű talajok szántóként hasznosulnak, a közepes minőségűeken hagyományosan kialakult és egyre jellemzőbb a szőlő- és gyümölcstermesztés. A mezőgazdasági területek mellett az ökológiai kiegyenlítő felületek (patakparti zöldsávok, rétek, legelők, nádasok) mozaikos felszínborításként jelennek meg (PILIS-BUDA-ZsÁMBÉK KISTÉRSÉG TERÜLETFEJLESZTÉSI KONCEPCIÓJA, 2009; BATRT FELÜLVIZSGÁLATA, 2011).

A medence fó vízgyüjtője a Békás-patak. A talajvízszint a völgyekben 2-4 m között, máshol 4-6 m között ingadozik. A talajvíz jelenlegi mélysége nem a természetes állapotot tükrözi; egyrészt az 1980-as években, a térséggel szomszédos Mány területén végzett szénbányászathoz kapcsolódó jelentős vízkivétel, másrészt az egyre növekvő lakossági és mezőgazdasági vízfogyasztás következménye. Az eredeti (vagy ahhoz közelítő) talajvízszint megjelenése hosszabb távon várható, a bányamüvelés megszünése és a víztakarékosságra ösztönző intézkedések eredményeképpen.

\subsubsection{Tájtörténeti áttekintés}

\section{A letelepedéstöl a rendszerváltásig}

A Zsámbéki-medence a kedvező letelepedési adottságok miatt ősidők óta lakott hely. Évszázados fejlődését változatos természeti adottságai mellett alapvetően meghatározta a kulturális, gazdasági és egyházi életben központi szerepet játszó városok - Székesfehérvár, Esztergom, Pest-Buda közelsége. Zsámbék a középkori egyházi és világi központot, Székesfehérvárt és Esztergomot összekötő útvonalon elhelyezkedő mezőváros, Biatorbágy pedig a Buda és Bécs közötti középkori kereskedelmi útvonal, a Mészárosok útja menti település volt.

A Zsámbéki-medence településeinek ősi szántóföldi kultúrájáról, római kori halászati- és fürdőkultúrájáról régészeti leletek tanúskodnak. A hagyományos szántóföldi gazdálkodás az itt élők alapvető megélhetési forrása volt évszázadokon át. A lösz alapkőzet a szőlő- és borkultúra alapja volt. A tájalakulás fő folyamata a történeti értékü katonai felmérések alapján a XVII. századtól nyomon követhető. Az első katonai felmérésen (1782-1785) a települések utcaszerkezete, a településekről kivezető utak, a nagy kiterjedésű hegyoldali szőlőterületek a hegyre vezető mélyutakkal, a patak menti területeket kísérő rétek, legelők, a patak mentén duzzasztott halastavak és a tavak alatti vízimalmok és a patak menti utak felismerhetők (6. ábra). A második katonai felmérésen (1829-1866) jól láthatók a patakok, valamint a fő mezőgazdasági és településközi utak mentén telepített fasorok - bár a Mária Terézia korabeli tudatos tájfásítás országos jelentőségéhez képest a fásítás itt kisebb mértékünek látszik. A harmadik katonai felmérés (1872-1884) a mérnöki birtokrendezéssel létrejött derékszögű úthálózatot ábrázolja. Azonosíthatók a szőlöhegyek. A természetes patakmedrek mellett Zsámbék és Tök területén megjelennek a szabályozott patakmedrek. 


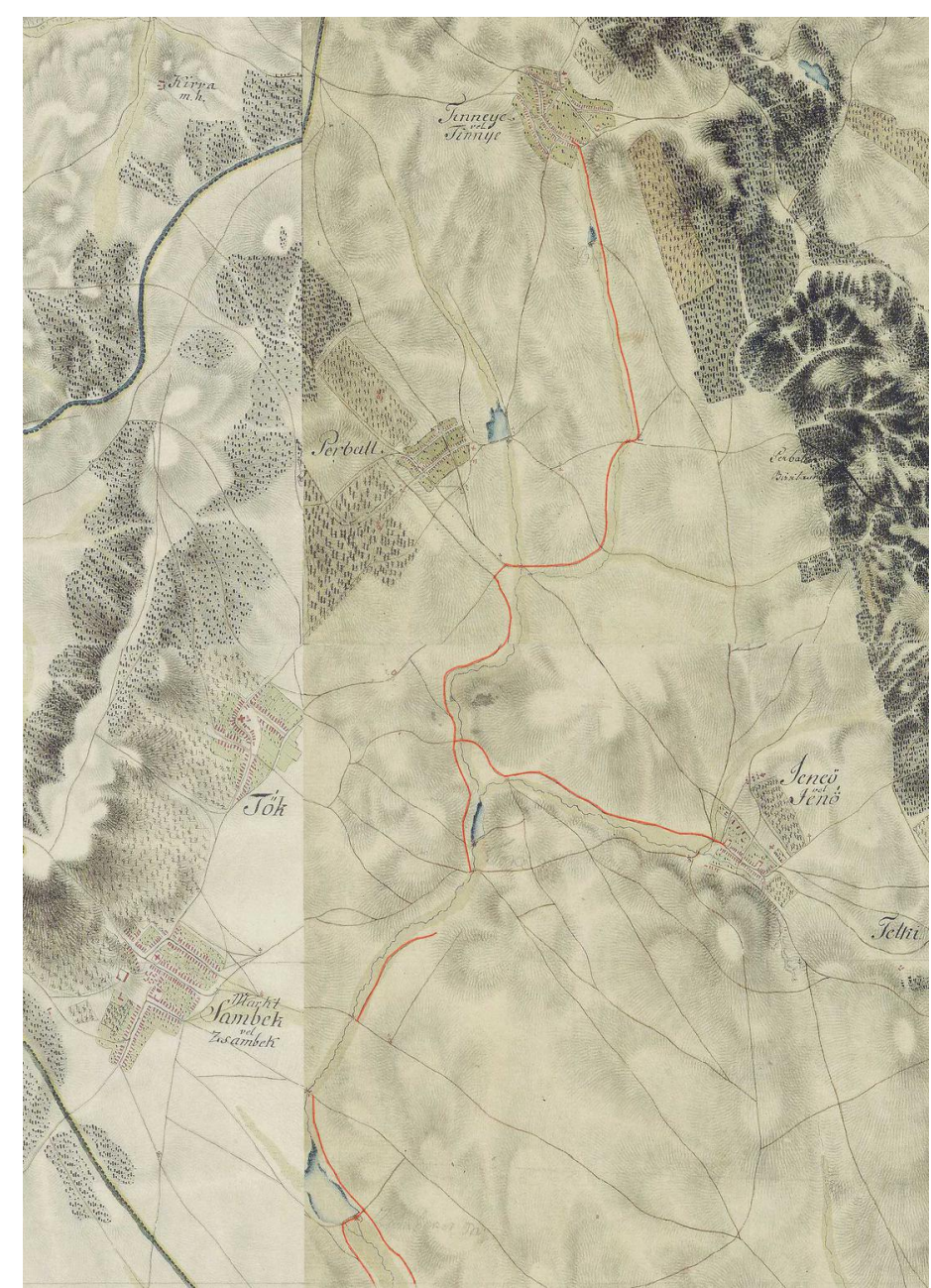

6. ábra: Hagyományos patak menti utak a Békás-patak és a Budajenői-patak mentén (saját szerkesztés, forrás: Első katonai felmérés, 1782-1785)

Az 1970-es évek nagyüzemi mezőgazdasága alapvetően átformálta a táj szerkezetét: nagyüzemi méretü táblákat alakítottak, a szölők, gyümölcsösök nagy részét megszüntették (ún. zártkertekké alakultak). A szántóföldi termesztést a patakok vonaláig kiterjesztették, ezért a vízparti növénytársulások keskeny sávra szükültek. A hagyományos szántóföldi parcellák közötti mezsgyéken telepített fasorok nagy részét kivágták.

\section{Szuburbanizációs folyamat}

A Zsámbéki-medence jövőképét alapvetően meghatározza az 1980-as években elkezdődött szuburbanizációs folyamat, illetve annak alapvető oka, a főváros környéki csendesebb, egészségesebb településekre történő kiköltözési hullám, amely számszerűen az agglomeráció területén mintegy 200 ezer fö, a Zsámbéki-medence területén mintegy 30 ezer fő - jellemzően fiatal házaspárok és családok letelepedését jelentette. A szuburbanizációs folyamat elemzésével, várható 
társadalmi és területfejlesztési következményeivel számos tanulmány foglalkozott, és annak hatására több fejlesztési projekt - köztük a tudásközpont és rekreációs fejlesztések tervét célzó Talentis program - született. A szuburbanizáció folyamatával párhuzamosan születtek meg a rendszerváltás következményeképpen szükséges új törvények, köztük az 1990. évi törvény a települési önkormányzatok működéséröl, az 1996. évi XXI. törvény a területfejlesztésről és a területrendezésről, az 1995. évi törvény az épített környezet védelméről. Ezen új törvények adta keretek között születtek meg a települések saját fejlesztési koncepciói és településrendezési tervei. A rendszerváltást követően az agglomerációra - és így a Zsámbéki-medence területére is - az első térségi terv 2005-ben került jóváhagyásra, amikorra már "lezajlottak a legfontosabb területrendezési folyamatok...a terv igen sok esetben csak konstatálni tudta a változásokat...így beindult egy szétterülő város-régió fejlődés, az ún. "urban spraw" folyamata (SCHNELLER, 2010.)." Az agglomerációs terv felülvizsgálatának törvényi elfogadására 2011-ben került sor. A felülvizsgálati terv kiemelt célja volt a környezeti szempontok érvényesítése...amely a települési önkormányzatok fejlesztési igényeivel sok esetben ellentétes volt (TózSA, 2002. P.)

A megkezdődött szuburbanizációs folyamat további alakulását alapvetően befolyásolja Budapest további fejlődése. Dolgozatomban a Zsámbéki-medence jövőképéhez kapcsolódóan azzal foglalkozom, hogy az eddig készült települési és térségi jövőképekben egyértelműen megfogalmazott - és a további beköltözők számától függetlenül megnövekedett - rekreációs igények kielégítését hogyan és milyen formában gazdagíthatja egy térségi szintű zöldút-hálózat, amely az olmstedi zöldmodell jellemzőit hordozza magában, szervesen illeszkedik a Zsámbékimedence táji adottságaihoz és tájtörténeti hagyományaihoz, megfelelő rekreációs alternatívát nyújthat a térség lakói és az ideérkező kirándulók számára, illetve mindez hogyan integrálható a területi és a települési tervezés rendszerébe az optimális úthálózat hosszútávú fennmaradása érdekében.

\section{Egyedi tájértékek}

A Zsámbéki-medence tájtörténetéről tanúskodnak azok a máig megörzött tájértékek, amelyek a táji adottságok, a megélhetést nyújtó tájhasználati módok és a gazdálkodáshoz kapcsolódó építmények megformálása közötti harmóniát tükrözik. A szőlő- és a borkultúrát jelző karakteres tájelemek a pincék és a pincesorok Zsámbékon, Tökön, Perbálon, Budajenőn, a pincehegy Pátyon. A hagyományos szántóföldi gazdálkodás értékes építészeti emlékei a magtárak és a malmok. A magtárak közül elhelyezkedése és építészeti kialakítása miatt különleges értéket jelent a telki skót bencés apátság majorságának megmaradt késő barokk magtárépülete Budajenőn. Jelentős agrártörténeti értékek még a magtárak Biatorbágyon és Pátyon, valamint a malomépület 
Zsámbékon. A mezőgazdasági termesztés mellett évszázadokon át a táji adottságokon alapuló megélhetést jelentett az erdőgazdálkodás, mészkő- és agyagbányászat.

\subsection{A zöldút modell térségi szintü alkalmazása}

A zöldút modell alkalmazhatóságát a 3. fejezetben bemutatott „1.ábra A zöldút modell hazai alkalmazhatóságának vizsgálatáról” (34. oldal) szerint elemzem a mintaterületnek tekintett Zsámbéki-medencére vonatkozóan.

\subsubsection{A zöldút-tervezés igénye}

A zöldút-tervezés a rekreációs és az ökológiai célú tájfejlesztés együttes megvalósítására irányul. Célja a gyalogos, a kerékpáros és a lovas kirándulási lehetőségek összehangolt tervezése természetes vagy természetközeli környezetben, táji léptékben. A zöldút-tervezés igényének vizsgálatát ezért egy adott tájegység területén meglévő szabadtéri rekreációs lehetőségek és igények, valamint az ökológiai adottságok és igények feltárására és elemzésére alapozom.

Szabadtéri rekreációs lehetöségek és igények

A Zsámbéki-medencében élők számára jelenleg a fő kirándulási lehetőséget a Budai-hegységhez tartozó erdők területén kijelölt turistaútvonalak jelentik (7.ábra). A kirándulók számáról felmérések nem készültek, de rendszeres kirándulások során egyértelmüen tapasztalható a kirándulók számának növekedése. A településekhez kapcsolódó turistautak elérése gépjármű használata nélkül lehetséges azokról a településekről, amelyeknek közvetlen kapcsolata van az erdőterületekkel (Zsámbék, Perbál, Budajenő, Telki, Páty, Biatorbágy). Az egyes településektől távolabbi turistautak eléréséhez gépkocsi használat szükséges (a tömegközlekedési lehetőségek nem jelentenek megoldást). A szabadidős kirándulási igény növekedését jelzi a főutak turistautakhoz kapcsolódó szakaszai mentén hétvégenként parkoló gépkocsik növekvő száma. 


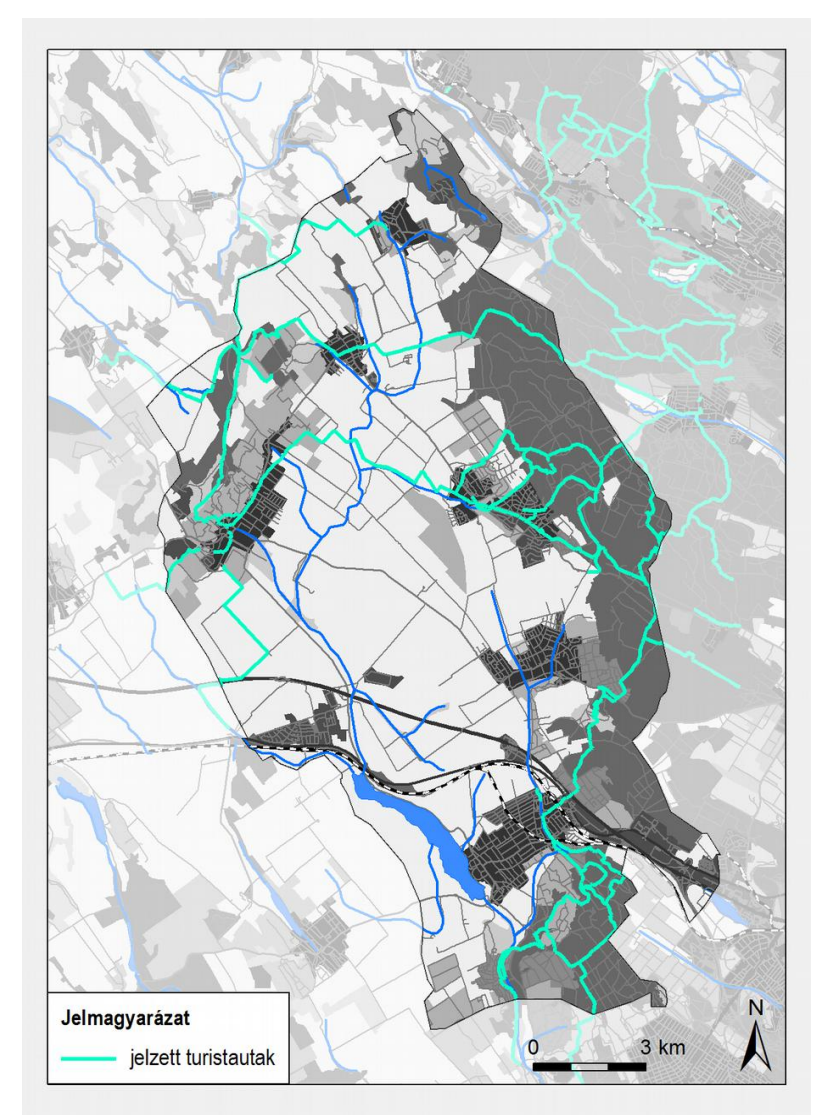

7. ábra: Kijelölt turista útvonalak (saját szerkesztés)

Kerékpározási lehetőséget jelenleg a településeket összekötő országos főutak és az erdei utak jelentenek. A főutakon jelentősen megnövekedett forgalom. A forgalom jellegének megváltozása (tehergépkocsik, nehézgépjármüvek számának jelentős növekedése) miatt a kerékpározás nem legfeljebb időszakosan - tekinthető biztonságosnak. A főutak lejtésviszonyai változatosak, kisgyermekes családoknak még a csekély forgalmú időszakokban sem jelentenek kényelmes lehetőséget. Az erdei utak a hatályos erdőtörvény értelmében szabadon használhatók kerékpározásra. Kényelmes és biztonságos használatuk azonban - a változatos terepadottságok és a változó útminőség miatt - korosztályok szempontjából szintén változó. Néhány település (Perbál, Telki, Biatorbágy) beépített területén rövidebb szakaszokon, egyes objektumok összekötését szolgáló önálló kerékpársávok épültek.

Kistáji léptékü kerékpárút fejlesztés célja a Zsámbéki-medence összes településének településfejlesztési koncepciójában szerepel. Kistérségi kerékpárút fejlesztési tanulmányterv 2009ben készült. (FEJÉREURÓPA, 2009). A tanulmánytervben javasolt kerékpárút hálózat elemei elsősorban a főutak nyomvonalához csatlakoznak, a terv ugyanakkor mezőgazdasági utak nyomvonalán vezetett szakaszokat is tartalmaz (a terv készítése során a tervezők figyelembe vették a Budavidék Zöldút egyes szakaszait is). 
A Budavidék Zöldút Szövetség által kijelölt zöldút-hálózatot meglévő, gyalogosan és kerékpárral is járható útvonalak alkotják. A zöldút-hálózat értéke, hogy jelenlegi állapotában is használható, a közúti forgalomtól elszakad, ezért a gépjárműforgalom okozta balesetveszélytől, zajés levegőszennyezéstől mentes környezetben vezet. Jelenlegi állapotában azonban csak időszakos használatra alkalmas az útfelszín változó minősége (kátyús vagy porzó útfelszín), a hosszú fátlan szakaszokon jellemző árnyékmentesség, az út menti pázsitfüvek és a kaszálatlan területeken terjedő gyomok allergizáló hatása, egyes szakaszokon a tulajdonviszonyok rendezetlensége, valamint a mezőgazdasági nehézgépek által használt szakaszok egyidejü rekreációs használatából adódó helyhiány miatt. A kijelölt zöldút-hálózatot ennek ellenére egyre többen használják, az útvonalakon szervezett közös tavaszi kerékpártúrák 3-400 résztvevővel zajlanak.

A lovaglás a Zsámbéki-medencében egyre népszerübb. Zsámbékon, Tökön, Perbálon, Pátyon, Biatorbágyon lovastanyák és lovasiskolák müködnek. A lovaglásra törvényi szabályozás értelmében a mezőgazdasági és az erdészeti utak egyaránt szabadon használhatók.

\section{Ökológiai adottságok és igények}

A Budai-hegységhez tartozó erdőterületek, valamint a Zsámbék és Tök területéhez tartozó Nyakashegy a Nemzeti Ökológiai Hálózat részeként ökológiai magterület, a Békás-patak és fö mellékpatakjai (Szamárhegyi-patak, a Budajenői-patak, a Kozáromi-patak), a Disznólápa és a Sasfészek-tó összefüggő ökológiai folyosót alkot. Az ökológiai magterületek környezetében mozaikosan pufferterületek vannak. Az ökológiai folyosó szélein kijelölt pufferterület nincsen. Az ökológiai folyosóhoz tartozó növénytársulások összetétele és értéke változó. A patakpartok egy része szántó müvelésü területtel határos, ugyanakkor foltokban, mozaikszerüen változatos összetételü vízparti füzligetek is előfordulnak.

\section{Mezőgazdasági tájfásítás nyomai}

A XVIII-XIX. századi katonai felmérések alapján jelentős tájfásítások a patakok és a fő településközi utak mentén történtek. Mezővédő szerepü tájfásítás Páty és Telki területén történt az 1940-es években a Budapesti Müszaki Egyetem tangazdasági programja keretében Páty és Telki területén, valamint az 1960-as években Zsámbék és Herceghalom területén.

\subsubsection{Tervezési elözmények}

\section{Civil zöldút javaslat}

A civil kezdeményezésü Budavidék zöldút-hálózatot a helyi társadalom kerékpározás iránti igénye hívta létre 2007 tavaszán. (www. bvz.hu) A zöldút-hálózatot alkotó útvonalak kiválasztása a KözépEurópai Zöldutak Szövetsége által összeállított útmutatóból kiindulva, helyi civil szervezetek és 
magánszemélyek helyismeretén alapuló közös helyszíni bejárások alapján, az érintett területek tulajdonosaival és fenntartóival történt egyeztetések alapján történt.(8.ábra)

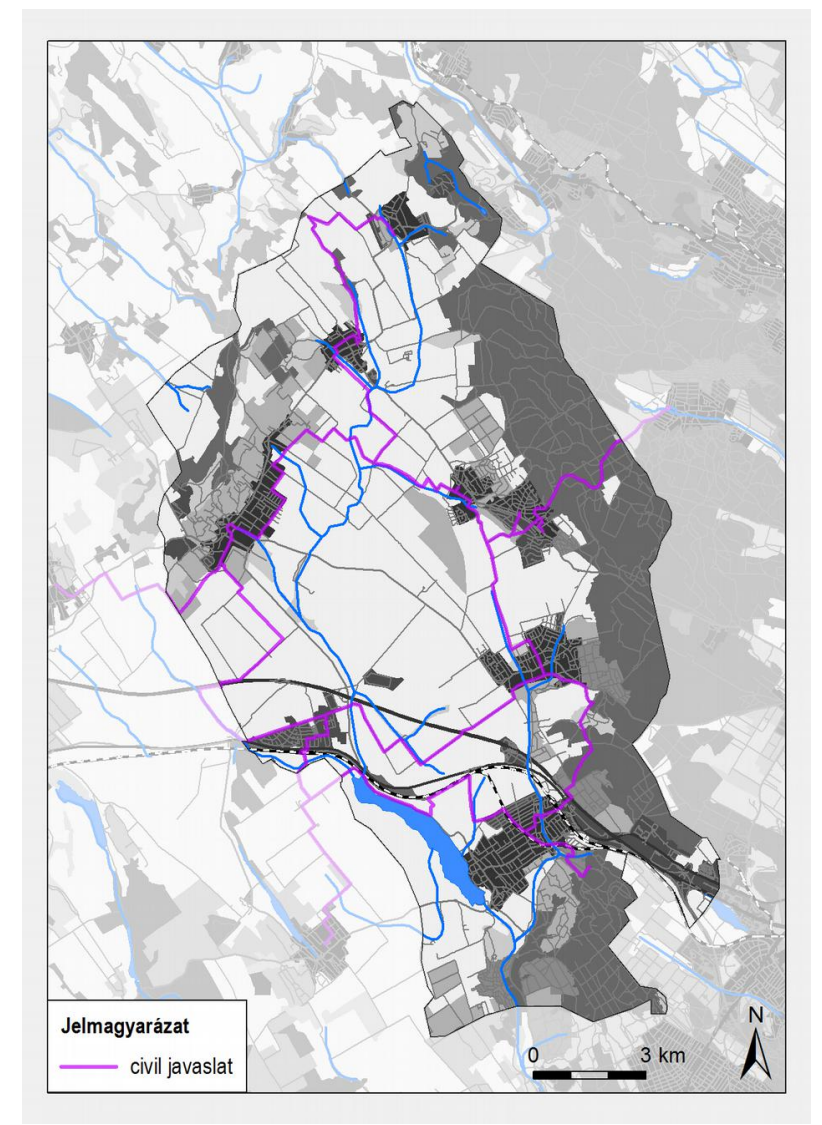

8. ábra: Civil úthálózat javaslat (saját szerkesztés)

A Budavidék zöldút-hálózat kijelölését meghatározó igények a következők voltak:

- meglévő, kerékpározásra és gyaloglásra alkalmas útvonalak legyenek;

— jelentős anyagi beruházás nélkül is használhatók legyenek;

— települések közötti kapcsolatot biztosítsanak;

— a települések között optimális lejtésű és hosszúságú útvonalak kerüljenek kiválasztásra;

— a települések központjain is áthaladjanak;

— a forgalmas közutaktól (a környezeti szennyezésektől és a balesetveszélytől) távol haladjanak;

— minél több értékes kilátási helyet és tájértéket felfüzzenek;

— forgalmas közutakat lehetőség szerint csak a települések beépített területén keresztezzenek. Az útvonalak részei lehetnek

— a meglévő kis forgalmú utak, utcák, 
— a meglévő erdei utak,

— a meglévő mezőgazdasági utak,

- a felhagyott vasúti nyomvonalak,

- a patakok mente,

- a szükséges új útszakaszok.

Az optimális kiválasztás érdekében az útvonalakat egyeztetni kell az érintett

— tulajdonosokkal és kezelőkkel,

— települési önkormányzatokkal,

- szakhatóságokkal,

- gazdálkodók tevékenységével,

- a terület- és településrendezési folyamatokkal,

- a természeti védelem alatt álló területek terhelhetőségével.

A terv véglegesítését befolyásolhatják

- a tulajdonosi és a kezelői viszonyok,

- a tervezett új területhasználatok és infrastrukturális létesítmények,

- a gazdálkodási gyakorlat (a fő gazdálkodási útvonalak),

- a vadászati tevékenység,

- a növényvédelmi tevékenység

\section{A Budajenö-Páty közötti szekérút feltárás bemutatása}

A Budajenő és Páty közötti egykori településközi utat (helyközi földutat) szóbeli tájékoztatások szerint a környéken élők közül sokan szekérútként vagy gyalogosan is használták gyerekkorukban. Kis esése miatt az egyik legjobb útkapcsolatot jelentette a két település között. Az út mellé egykor kettős fasort ültettek, amely között a szekerek, majd később a kisebb traktorok közlekedését elegendően széles út biztosította. A szélesebb mezőgazdasági gépek megjelenésével a szekérút elbozótosodott, és a mezőgazdasági gépek a régi szekérút melletti területet kezdték használni. Kialakult egy újabb földút, amely útként földhivatali bejegyzésre is került. Az útvonal a Budavidék Zöldút hálózat kijelölésénél kiemelt figyelmet kapott, és a szükséges egyeztetések után a mintegy 40 km-es körtúrát jelentő zöldút-hálózat részévé vált. Az útszakasz Telki község közigazgatási területéhez tartozik. A civil egyesület és az önkormányzat közötti egyeztetések eredményeképpen az önkormányzat anyagi támogatásával a régi, elbozótosodott, mintegy $800 \mathrm{~m}$ hosszú szakasz gyalogos és kerékpáros használat számára kitisztításra került. A szekérút feltárást minta értékünek 
tartom hasonló elbozótosodott szekérutak rekreációs célú feltárására, ugyanakkor a fátlan mezőgazdasági földutak mellett fásítással kialakítható zöldutak létesítésére is. (9.ábra)
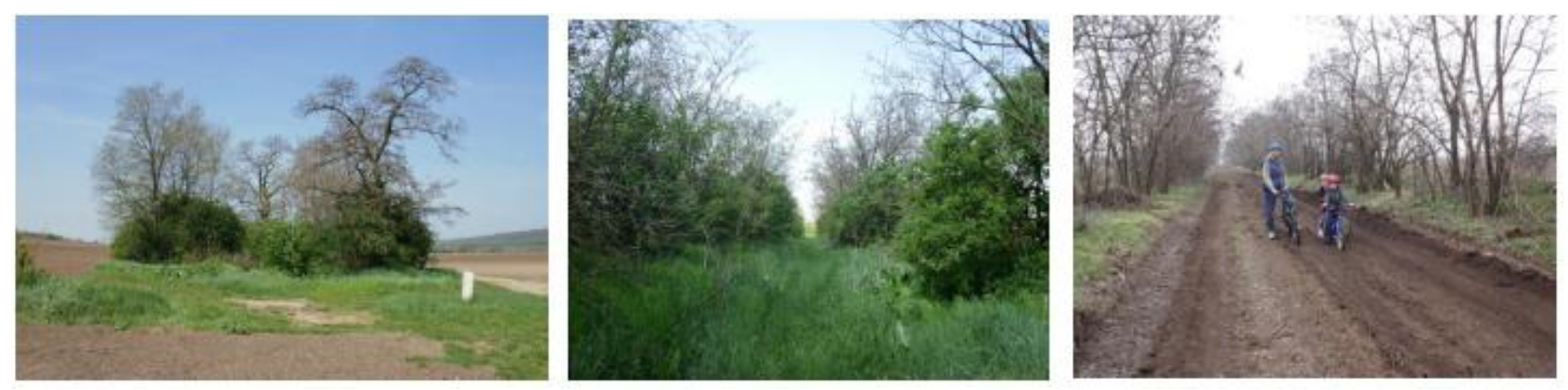

9. ábra: A Budajenö és Páty közötti szekérút feltárása önálló használatú zöldútként

Tájépítészeti szemmel tekintve a szekérút feltárás példája ráirányította a figyelmemet a hagyományos településközi utak tájszerkezeti jelentőségére, valamint a hagyományos tájhasználatok mai igényekhez illeszthető hasznosítási lehetőségére.

\section{Kistérségi kerékpárforgalmi tanulmányterv}

A kerékpározás iránti igényt érzékelve Budaörs Kistérség Többcélú Társulása megbízásából tanulmányterv készült a Zsámbéki-medence kistérségi kerékpárforgalmi hálózat fejlesztése céljából (FEJÉREURÓPA, 2009). A tervezők a tanulmánytervbe beépítették a Budavidék Zöldút egyes szakaszait is. A tanulmánytervben a nyomvonalak egy része burkolt útként (elsősorban az országos főutak mentén), más részük javított földútként (elsősorban mezőgazdasági területeken) szerepel. A tanulmányterv kiemelt értéke, hogy térségi szinten hangolta össze az egyes települések fejlesztési igényeit.

\section{Tájépitészeti hallgatói munkák}

Kutatásaim megkezdését követően külső konzulensként bekapcsolódtam a Budapesti Corvinus Egyetem Tájtervezési és Területfejlesztési Tanszékén folyó oktatási munkába. A Zsámbékimedencében alakuló civil zöldút program használata során tájépítészként észlelt tapasztalatokat megosztva részt vettem a zöldút-tervezésre irányuló hallgatói feladatok összeállításában és kidolgozásában. Az első közös féléves hallgatói feladat vizsgálati munkarészében a hallgatók a Budavidék Zöldút Szövetség által által javasolt útvonalak adottságait vizsgálták:

— a javasolt útvonalakat a szükséges tájépítészeti feladatok szerint szakaszokra bontották;

— néhány település esetében újabb zöldútvonal szakaszok kialakítására tettek javaslatokat;

— meghatározták az ökológiai szempontból különösen értékes rendszerelemeket; 
— jelölték a zöldútvonalak mentén található tájértékeket és értékelték állapotukat;

— ábrázolták az értékes kilátási- és rálátási pontokat.

A tájértékelési munkarészben meghatározták és csoportosították a zöldút használat során észlelhető tájhasználati konfliktusokat ${ }^{5}$ :

- kátyús, elhanyagolt útfelszín,

— fátlan mezőgazdasági terület (defláció),

— kevés a kondicionáló zöldfelület (fasorok hiánya),

- kóbor kutyák jelenléte,

- engedély nélküli hulladéklerakás,

— kevés útjelző miatti nehéz útkövetés,

— zöldút-meglévő/tervezett közút kapcsolata,

- a változó terepviszonyok.

A tájhasználati konfliktusok feloldására a következő javaslatok születtek:

— útfelszín kialakítási lehetőségek kidolgozása hét alaphelyzetre,

— mezővédő erdősávok kialakítása,

— út menti fásítás,

— zöldút-hálózat figyelembe vétele a tervezési folyamatok során,

— mezőőri szolgálat megszervezése,

- terepi viszonyok jelzése,

— zöldutak jelölése aszfalton, táblákkal is,

— engedély nélküli hulladéklerakások felszámolása. (SALLAY-KAPOVITS, 2010)

A zöldútvonalakhoz kapcsolódóan több tanösvény javaslat született: a Budajenő és Páty közötti egykori szekérút nyomán a tájtörténetet és a mezőgazdasági kultúrákat bemutatását, a Tök és Páty közötti - feltehetően római hadi- és kereskedelmi útként is használt - szakaszon az ókori római kultúra bemutatását, a Biai-tó mentén pedig a vízi és vízparti növény- és állatvilágot bemutatását lehetővé tevő tanösvény-terveket dolgoztak ki a hallgatók.

5 Egy adott tájban megfigyelhető egymást zavaró, egymást akadályozó tájhasználatokat a tájépítész szakma tájhasználati konfliktusnak nevezi. A tájhasználati konfliktusokat három csoportba sorolhatjuk: tájökológiai, funkcionális és tájesztétikai konfliktusokat különíthetünk el. „Funkcionális konfliktust az egymást akadályozó, egymás területét megszüntető, rendeltetését zavaró, egymással konkuráló területhasználatok okoznak. Tájökológiai konfliktust (nézőpont, illetve megközelítés kérdése, hogy az adott hatást a környezet szennyezéseként vagy az ökológiai adottságok károsításaként minősítjük) az egymást károsító, pusztító, megszüntető, egymás létét veszélyeztető területhasználati módok okozzák. Vizuális-esztétikai konfliktust a „csúnya” látvány, a rendezetlenség, a rendetlenség, a megoldatlanság, a befejezetlenség, a folyamatosság érzékelhető megszakadása, hiánya okoz.” (CSEMEZ, 1996) 
A tájfejlesztési javaslatok érintették a zöldút turisztikai fejlesztési lehetőségeit is. Hangsúlyozni kell azonban, hogy szélesebb körü turisztikai népszerüsítés csak a tájhasználati konfliktusok feloldását követően, és a zöldút-hálózat teljes területén egyformán biztonságos felszínű, útjelzőkkel megfelelő sủrüségben ellátott utak biztosításával javasolható. Jelenlegi állapotában a zöldút csak a helyi, kistérségi igények kielégítésére alkalmas (SALLAY-KAPOVITS, 2010).

\subsubsection{Tájszerkezeti lehetőségek elemzése}

\section{Vizparti területek}

A Békás-patak menti táj szakaszai leírhatók Báthoryné Nagy Ildikó Réka által megalkotott patak menti tájrészlet-tipizálása szerint (BÁTHORINÉ NAGY, 2006). A Zsámbéki-medence területén a szántóföldi patak menti táj dominál, amelyben természetközeli és - a szántók vízvédelme érdekében - átalakított patakszakaszok váltakoznak. Réti patak menti tájrészletek is találhatók, ahol a meder környezetében nem kritérium az árvízmentesítés, ezért többnyire természetes meder- és partszakaszok jellemzők. A falusias és kertvárosias patak menti tájrészleteknél a patakokhoz a beépített telkek a kertrészletekkel kapcsolódnak. A Békás-patak egykori halastóvá duzzasztott szakaszain duzzasztógátak nyomai helyenként azonosíthatók. A Békás-patak alsó szakasza a duzzasztott Biai-tó és a Pecató Biatorbágyon.

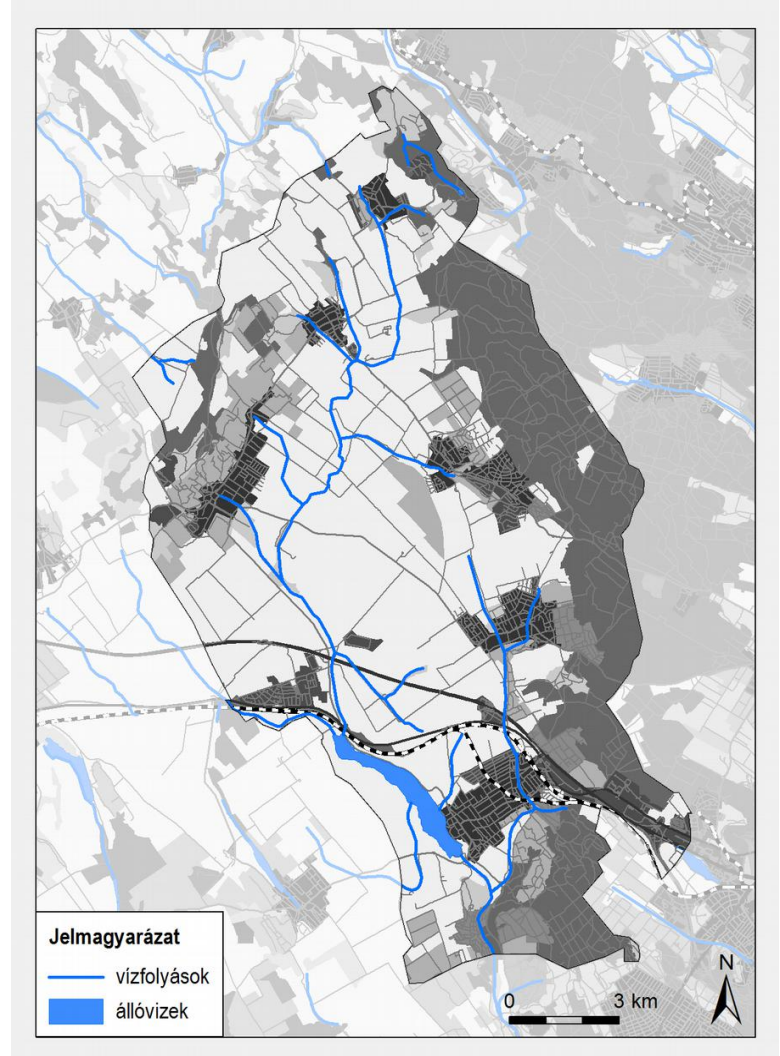

10. ábra: Felszini vizek a Békás-patak vízgyüjtő területén (saját szerkesztés) 
A vizparti területek az érvényes területrendezési tervekben

A patakok és a patak menti területek tervezési lehetőségeit a területrendezési tervek területfelhasználásra és övezetekre vonatkozó szabályai együttesen határozzák meg. ${ }^{6}$ A patakmedrek az országos és a térségi szerkezeti tervekben területfelhasználás szerint a vízgazdálkodási térségbe tartoznak ${ }^{7}$.

A vízparti területek ökológiai szempontból értékes vízparti vegetációinak védelmét az országos és a térségi övezetképzés eszközével lehet biztosítani. Az Országos Területrendezési Terv alapján a Békás-patak, a Perbáli-patak, a Budajenői patak, a Zsámbéki-patak, a Disznólápa, a Füzes-patak és a Papréti-patak menti területek az ökológiai hálózat övezetébe tartoznak. ${ }^{8}$

\section{A vízparti területek a településrendezési tervekben}

A vízparti területek besorolása a településrendezési tervekben - a területrendezési tervekben meghatározott térségi területfelhasználási kategóriának (vízgazdálkodási térség) megfelelően vízgazdálkodási területként vagy természetközeli területfelhasználási egységként lehetséges. A vizsgált mintaterülethez tartozó települések településrendezési terveiben a vízparti területek mindenütt vízgazdálkodási területként vannak lehatárolva. A területrendezési tervekben alkalmazott térségi övezeti kategória - ökológiai folyosó övezete - figyelembevétele a településrendezési tervekben védőterület vagy védőövezet kijelölésével történt, melynek értelmében a természetközeli

6 A Zsámbéki-medence területére vonatkozó országos és kiemelt térségi (Budapesti Agglomeráció) területrendezési tervek elöírásai törvényi erejü kötelezettségeket jelentenek.

7 Az Országos Területrendezési Terv fogalommeghatározása alapján a "vízgazdálkodási térség: országos, kiemelt térségi és megyei területrendezési tervben megállapított területfelhasználási kategória, amelybe Magyarország felszíni vízrajzi hálózata (vízfolyások és tavak) és parti sávja tartozik." Az OTrT 6. § (1) e) bekezdésben meghatározott térségi területfelhasználási szabály szerint "a kiemelt térségi és a megyei területfelhasználási kategóriák kijelölése során ...a vizgazdálkodási térséget legalább 90 \%-ban vizgazdálkodási terület vagy természetközeli területfelhasználási egységbe kell sorolni." A 6. §. (2) e) szerint pedig "A települési területfelhasználási egységek kijelölése során... a vízgazdálkodási térséget legalább 85 \%-ban vízgazdálkodási terület vagy természetközeli területfelhasználási egységbe kell sorolni."

A Budapesti Agglomeráció Területrendezési Terve 10.§. szerint: " A vízgazdálkodási térséget legalább 95\%-ban vizgazdálkodási terület, illetve természetközeli terület területfelhasználási egységbe kell sorolni. A fennmaradó részen olyan területfelhasználási egység jelölhetö ki, amely nem veszélyezteti a vízgazdálkodás érdekeit."

8 Az ökológiai hálózat (ökoháló) övezet lehatárolása a Nemzeti Ökológiai Hálózat adatai alapján történt.

Az OTrT 13. §. (1) szerint "Az országos ökológiai hálózat övezetben csak olyan kiemelt térségi és megyei területfelhasználási kategória, illetve olyan övezet jelölhető ki, amely az ökológiai hálózat természetes és természetközeli élőhelyeit és azok kapcsolatait nem veszélyezteti. " A Budapesti Agglomeráció Területrendezési Tervében a patak menti területek az országos ökológiai hálózat övezetén belül az ökológiai folyosó övezetébe lettek sorolva, így azokra az OTrT. 18. §. elóirásai vonatkoznak, melyek közül a zöldút-tervezést érintheti a (4) pont: " $A z$ övezetben a közlekedési és energetikai infrastruktúra-hálózatok elemeinek nyomvonala, az erömüvek és kiserömüvek az ökológiai folyosó és az érintkezö magterület természetes élőhelyeinek fennmaradását biztositó módon, az azok közötti ökológiai kapcsolatok müködését nem akadályozó müszaki megoldások alkalmazásával helyezhetö el." 
állapotú felszíni vízfolyások mindkét partján külterületen, a telekhatártól mért $50-50 \mathrm{~m}$ széles természet- és vízvédelmű érdekü védőövezetek kerültek lehatárolásra ${ }^{9}$. Meg kell jegyezni, hogy a part menti területek valós ökológiai állapota eltérő, azonban egységes térségi övezeti és települési védőövezeti lehatárolása lehetővé teszi a vízparti területek egységes tervezését.

\section{Zöldút kialakítás lehetősége a vízparti területeken}

A Zsámbéki-medence vízparti területei több szempontból jó adottságnak tekinthetők zöldutak számára, mert

— a patakok dombvidéki és síkvidéki jellege miatt a part-menti sáv lejtése kicsi;

— a vízfelület miatt a helyi klíma a szomszédos szántóföldi területekhez képest kellemesebb;

— a patakok egyes szakaszain meglévő természetes vízparti fás növényállomány árnyékot ad, csökkenti a szálló por mennyiségét és tovább javítja a helyi klímát;

— a patakok egyes szakaszain meglévő, önálló útként bejegyzett utak vannak;

- a Békás-patak a Dunába torkollik, ezért a Békás-patak menti zöldút kapcsolódhat a részben már kiépített, részben tervezett Duna menti kerékpáros útvonalhoz;

— a patakpartok két oldala jó lehetőséget jelent a gyalogos-kerékpáros és a lovas használat térbeli elválasztására.

A vízparti zöldút tervezésénél megoldandó feladatot jelentenek a következők:

- növénytelepítés azokon a szakaszokon, ahol az eredeti vízparti fás növényállomány hiányzik,

— új út létesítése és bejegyzése azokon a szakaszokon, ahol nincs önálló útként bejegyzett út;

— a térségi területrendezési tervekben ökológiai folyosóként kijelölt övezetekre, illetve a településrendezési tervekben az övezeti elöírásoknak megfelelően kijelölt természetvédelmi védőövezetek szabályozási előírásainak figyelembe vétele;

— a part menti nyomvonaltól eltérő lehetőséget kijelölése ott, ahol a patakok egyes szakaszai kerítéssel lezárt erdőterületen vagy magánterületen vezetnek.

Kiemelt feladat a patakok és a közúti, valamint a vasúti töltések csomópontjainak megoldása.

\section{Felhagyott vasútvonalak}

A harmadik katonai felmérésen már szerepel az 1883-84-ben Budapest-Kelenföld-Újszőny között kiépített vasútvonal Bia és Torbágy közötti nyomvonala. A vasúthoz kapcsolódóan azonosítható a ma is látható kettős völgyhíd is. Az eredeti nyomvonalat 1977-ben pályakorszerüsítés miatt megszüntették, az új nyomvonal Biatorbágy keleti szélére került. A régivasútnak elnevezett

9 Zsámbék, Tök, Perbál hatályos Helyi Építési Szabályzatai alapján 
nyomvonal egy része a településközpont aránylag kis forgalmú közlekedési tengelyévé vált. A város beépített területén kívül eső részei feltáratlanok. Keleti, elbozótosodott részét helyi önkéntes akciókkal több ízben megtisztították. A tisztított szakasztól a viadukton át a településközpontig tartó szakasz így a helyi lakosság használata által séta- és kerékpározási funkciót kapott. A hasznosítás igényét és lehetőségét jelzi a helyi vasútbarátok köre által a viadukt nyugati hídföje és a településközpont közötti 300 m hosszú kiépített keskeny nyomtávú vasútvonal, amelyet a város nevezetes programjaihoz kapcsolódóan alkalmanként hajtányozásra, kisvonatozásra használnak. A régivasút nyugati szakasza egy rekultiválandó hulladéklerakóhoz vezető gazdasági útvonal szerepét tölti be. (11.ábra)

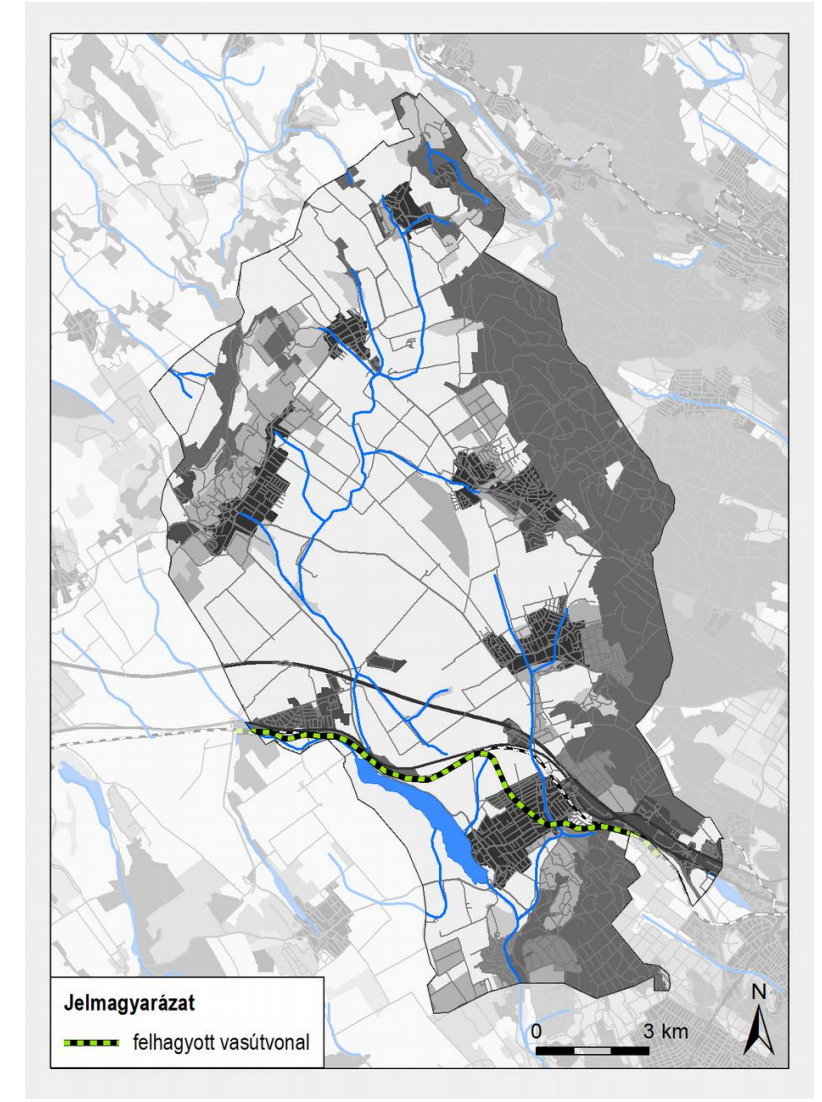

11. ábra: A felhagyott vasútvonal Biatorbágy területén (saját szerkesztés)

A régivasúti nyomvonal a területrendezési és településrendezési tervekben és kerékpár fejlesztési koncepciókban

Az Országos Területrendezési Tervben az országos müszaki infrastruktúra-hálózatok elhelyezésére vonatkozó szabályok között meghatározásra került, hogy „A kiemelt térségi és megyei területrendezési tervben szereplő regionális és egyéb vasúti pályák közül azok területét, amelyen a közszolgáltatás szünetel vagy megszünt, a településszerkezeti tervben beépítésre nem szánt 
közlekedési terület területfelhasználási egységbe kell sorolni."10

A felhagyott vasútvonalak esetében a közszolgáltatás újraindítása vagy végleges megszüntetése összetett gazdasági, társadalmi és közlekedéspolitikai kérdés. A mintaterületen található régivasút esetében azonban a vasúti közlekedés visszaállítása nem merül fel, mert a felhagyott nyomvonal helyett pályakorszerüsítés miatt új nyomvonal került megépítésre.

A felhagyottá vált szakaszok és a vasúti töltések szakaszainak kerékpárútként való hasznosítása több ízben megfogalmazódott. Elsőként a Magyar Kerékpáros Szövetség vetette fel egy úgynevezett AlterVelo kerékpáros útvonal kialakítását Budapest és Tata között, a Duna menti EuroVelo kerékpáros útvonal nehezen megvalósíthatónak tűnő szakaszának kiváltására. A Zsámbékimedencében alakuló a Budavidék Zöldút Szövetség javasolta a régivasút területének zöldútként való kijelölését. A Zsámbéki-medence területére készült kistérségi kerékpárútforgalmi tanulmánytervben szintén szerepel a régivasút területének kerékpározási célú hasznosítása, stabilizált földútként való kialakítási megoldással. A régivasúti nyomvonal egy része a BudapestBalaton kerékpárút folyamatban lévő koncepciótervében javasolt nyomvonalaként szerepel.

\section{Zöldútkialakitás lehetősége szabadtértervezési hallgatói tanulmánytervben}

A régivasút területének nem csak térségi rekreációs szerepe lehet, hanem Biatorbágy településközpontjában lévő szakasza a város karakteres zöldfelületi elemévé is válhat. A Budapesti Corvinus Egyetem Kert- és Szabadtértervezési Tanszékén készült hallgatói tanulmányterv készítői bemutatták, hogy a régi vasút nyomvonalán kialakítható zöldút a szokásos - közút mentén vezetett - kerékpáros útvonalak mellett olyan séta- és kerékpározási lehetőséget jelenthet, amely egy meglévő, de kihasználatlan, településszerkezeti szempontból jelenleg hulladékterületnek tekinthető helyen hoz létre jelentős zöldsávban futó, szabadtéri pihenőhelyekkel kombinált séta- és kerékpározási lehetőséget. A koncepciók mindegyike felhívta a figyelmet a zöldút menti területek egységes elvek mentén történő tervezés fontosságára, és ezáltal egy karakteres parkszerü, lineáris láncolat kialakításának lehetőségére a viadukt környezetében (HUTTER ET AL, 2014).

\section{Hagyományos útvonalak}

Az első katonai felmérésen egyértelmüen felismerhetők a mai települések legkorábban kialakult településmagjai és a települések közötti térségi útkapcsolatok is. A települések utcái a szomszédos települések felé vezető utakban folytatódtak. Minden településnek minden szomszédos településsel létezett - egy vagy több - összekötő útvonala. A felmérés a legfőbb útvonalak mellett ábrázolja a térséget feltáró egyéb, gazdálkodás során használt utakat is. A térségen áthaladó országos jelentőségü útvonalak - a Bécset Budával összekötő, a Biát és Torbágyot is érintő „mészárosok

10 OTrT 9/A.§. 
útja" - azonosíthatók. A Zsámbékon is áthaladó Székesfehérvárt Esztergommal összekötő középkori út nyomvonala a térkép alapján feltételezhető.

Tájszerkezeti szempontból - zöldút-hálózat kialakítása szempontjából is - különösen értékesek azok a településközi összekötő utak, amelyek mezőgazdasági útként fennmaradtak. (12. ábra)

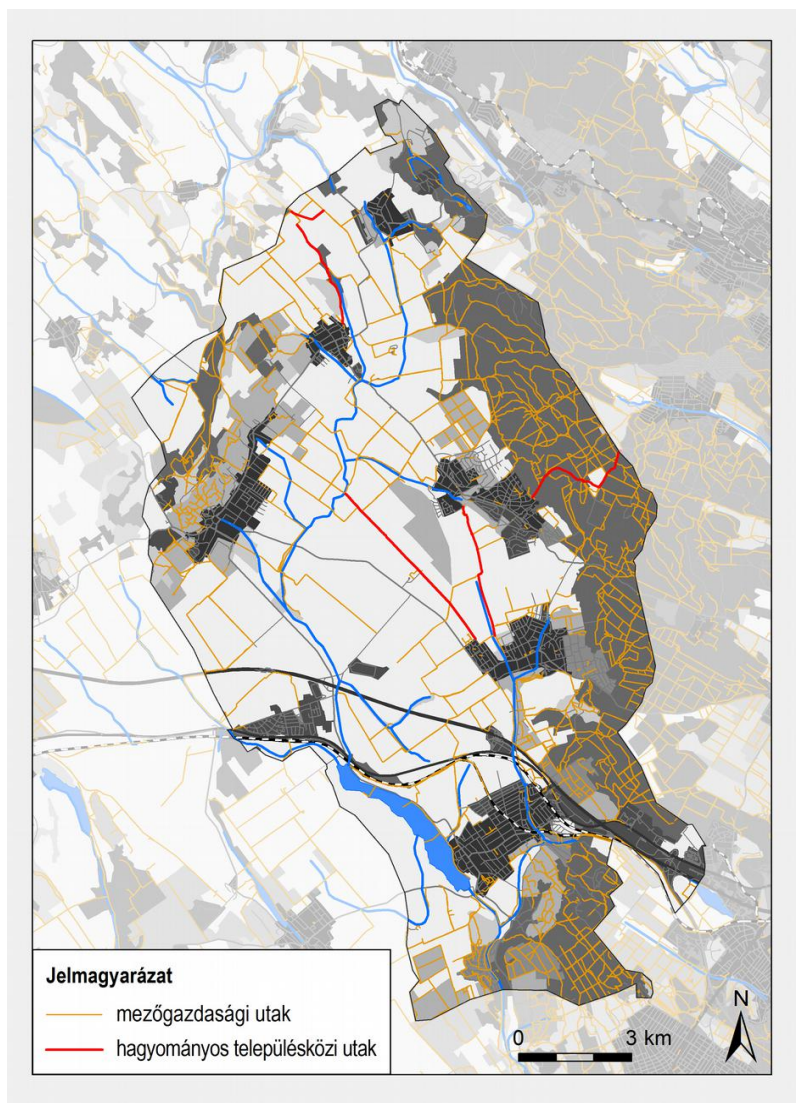

12. ábra: Mezögazdasági úthálózat a hagyományos településközi utak kiemelésével (saját szerkesztés)

Az egykori gazdálkodási és kereskedelmi utak egy részének nyomvonalán épültek ki a településeket összekötő, országos vagy térségi jelentőségü főutak. Más részük a mezőgazdasági úthálózat részévé vált, melyek kiépítettsége különböző mértékü. Fontos kiemelni, hogy a mezőgazdasági utak elsődleges szerepe a gazdálkodáshoz kapcsolódó közlekedési igények kielégítése. Szerepük szerint három szint különíthető el:

— gerinchálózat: települések, telepek, majorok közötti mezőgazdasági bekötőutak, feltáróutak alkotják, általában út müvelési ágba sorolt, önálló helyrajzi számmal ellátott földrészletek;

— termelési hálózat: termelöegységek közötti telepi belső utak alkotják, csatlakoznak a bekötőutakhoz;

— termőterületi hálózat: mủveleti utak alkotják, amelyek a termőterület részei, a termelés technológiájának változásával együtt változnak, a termesztési cél megváltozásakor ismét 
termőfölddé válnak, ezért útnak nem tekinthetők.

A gerinchálózat és a termelési hálózat együttesen alkotják a mezőgazdasági úthálózatot. Amely kapcsolatot teremt a mezőgazdasági termelés helyszínei és a közforgalmú hálózatok között. A termőterületi hálózat a termőterület saját hálózata, a termeléstechnika része, és mint ilyen nem tartozik semmilyen szabályozás körébe (KOSZTKA, 2010).

\section{A mezögazdasági utak jelenlegi állapota}

A mintaterületen található mezőgazdasági utak állapota az adott talajtípustól, a vízelvezetési megoldástól és a fenntartási munkák gyakoriságától függően változó. Az utak a gazdálkodáshoz szükséges közlekedés számára megfelelőek, a különféle kirándulási formák szempontjából állapotukat különbözőképpen értékelem. Lovaglás számára a földutak teljesen alkalmasak, gyaloglás számára elfogadhatóak, kerékpározás szempontjából problémát jelentenek a kátyús, nyomvályús szakaszok, a lovaglás miatt göröngyössé váló szakaszok. Az út menti fásítások hiánya elsősorban a gyalogos kirándulás szempontjából kellemetlen, kerékpározás szempontjából a kisgyermekek számára jelent gondot. Zöldútfejlesztési szempontból alapvetőnek tekintem, hogy a mezőgazdasági területeken az elsődleges tájhasználat a gazdálkodás, a rekreációs funkció másodlagos tájhasználatként merül fel.

\section{A mezögazdasági útként fennmaradt hagyományos településközi összekötö utak}

A helyközi földutakat évszázadokkal ezelött a szekeres-lovaskocsis használat céljára építették ki, elsősorban a gazdálkodási és a piaci-kereskedelmi tevékenységhez kapcsolódóan. A helyi hagyomány és az emlékezet szerint a szomszédos falvak közötti rokonlátogatások útvonalai rendre a településközi összekötő utak voltak. Ez utóbbi lehetősége a II. világháború után szünt meg, e földutak elhanyagolása vagy beszántása következtében. A szomszédos települési vagy egyéb célpontokra a beépített területeken ma is fennmaradt utca- és dűlőnevek is utalnak (Töki út Pátyon, Pátyi út Budajenőn, Jenei dủlő Pátyon, Annalaki út Telkiben). A települések közötti földutak búcsújárások, zarándoklatok útvonalai is voltak: a Telkin és Nagykovácsin át vezető úton jutottak a zarándokok Máriaremetére. A hagyományosan kialakult településközi utak egy része térségi szerepü fớttá vált, más része földútként maradt fenn.

\section{Mezögazdasági utak a területrendezési és a településrendezési tervekben}

A mezőgazdasági utak a területrendezési tervekben önállóan nem jelennek meg, a mezőgazdasági térség kategóriához tartoznak. A településrendezési tervek szerkezeti terveiben önálló területfelhasználási egységként nem jelennek meg - a mezőgazdasági területhez tartoznak nyomvonalukat azonban a szerkezeti tervekben ábrázolják. A szabályozási tervekben az önálló 
helyrajzi számmal rendelkező külterületi utakat a földhivatali nyilvántartás szerinti szabályozási szélességükkel ábrázolják, és a közlekedési területek övezetébe sorolják.

A településközi földutak általában út művelési ágba sorolt, önálló helyrajzi számmal rendelkező földrészletek. Jelentőségük miatt ezek fejlesztése mezőgazdasági szempontból is kiemelt vidékfejlesztési feladatnak tekinthető, melynek során különös tekintettel kell lenni az eltérő földtulajdonosi és földhasználói igények egyeztetésére (KosZTKA, 2010).

zöldút-tervezés lehetösége a hagyományos településközi utak mentén

A mezőgazdasági utak szerepe elsősorban a gazdálkodási tevékenységhez szükséges közlekedés biztosítása. Egyéb használatukra vonatkozó korlátozó jogszabály nincsen. Gyalogos közlekedésre, lovaglásra évszázadok óta használták azokat. A szabadidős kerékpározás iránti egyre nagyobb igény jelentkezésével a mezőgazdasági utak egy részét a helyi lakosság kerékpározásra is használni kezdte. A Budajenő-Páty közötti - többszöri bejárás során felfedezett, majd a Budavidék Zöldút Szövetség szervezésében gyalogos- és kerékpározás számára zöldútként feltárt - egykori településközi út történeti elemzésével szeretném alátámasztani és megerősíteni a hagyományos településközi utak tájtörténeti és tájszerkezeti jelentőségét, rekreációs szerepü útvonalként lehetséges hasznosításukat.
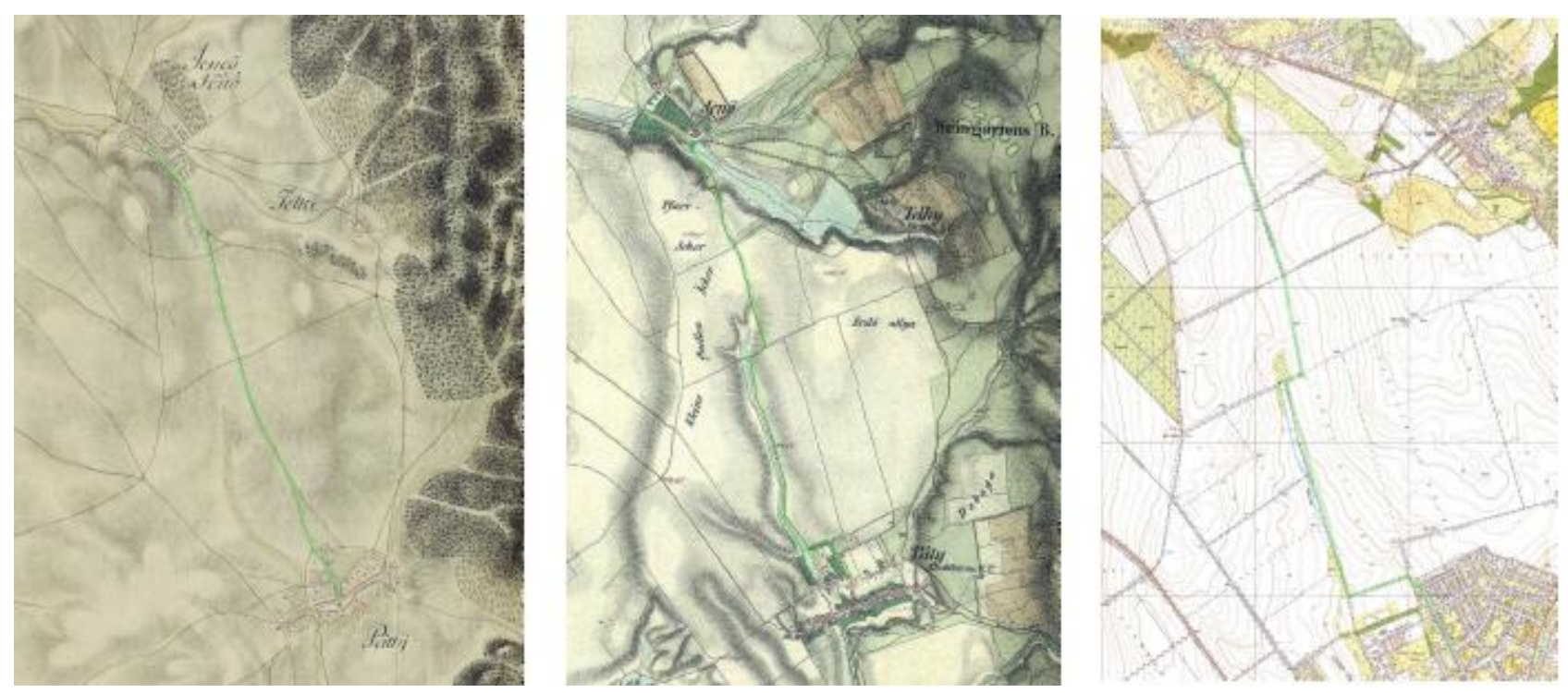

13. ábra: A Budajenő és Páty közötti településközi összekötő út az első (1782-85) és a második (1829-1866) katonai felmérésen, valamint topográfiai térképen (2000)

A történeti térképek alapján a Budajenő és Páty közötti településközi összekötő út évszázados léte egyértelmüen bizonyított. Az út - jelenlegi állapota szerint - három szakaszra osztható:

— Az út felső szakaszának zöldútként való feltárását az tette lehetővé, hogy a hagyományos, $6 \mathrm{~m}$ széles útvonal mentén ültetett kettős juhar fasor megmaradt. A fasorok közötti terület a használat megszünését követően elbozótosodott, és mezőgazdasági használat céljára a régi 
szekérút mellett létrejött egy új földút. Az új földút önálló földrészletként földhivatali bejegyzésre került, ezért a feltárás csak önkormányzati tulajdonú földrészletet érintett.

(14. ábra)
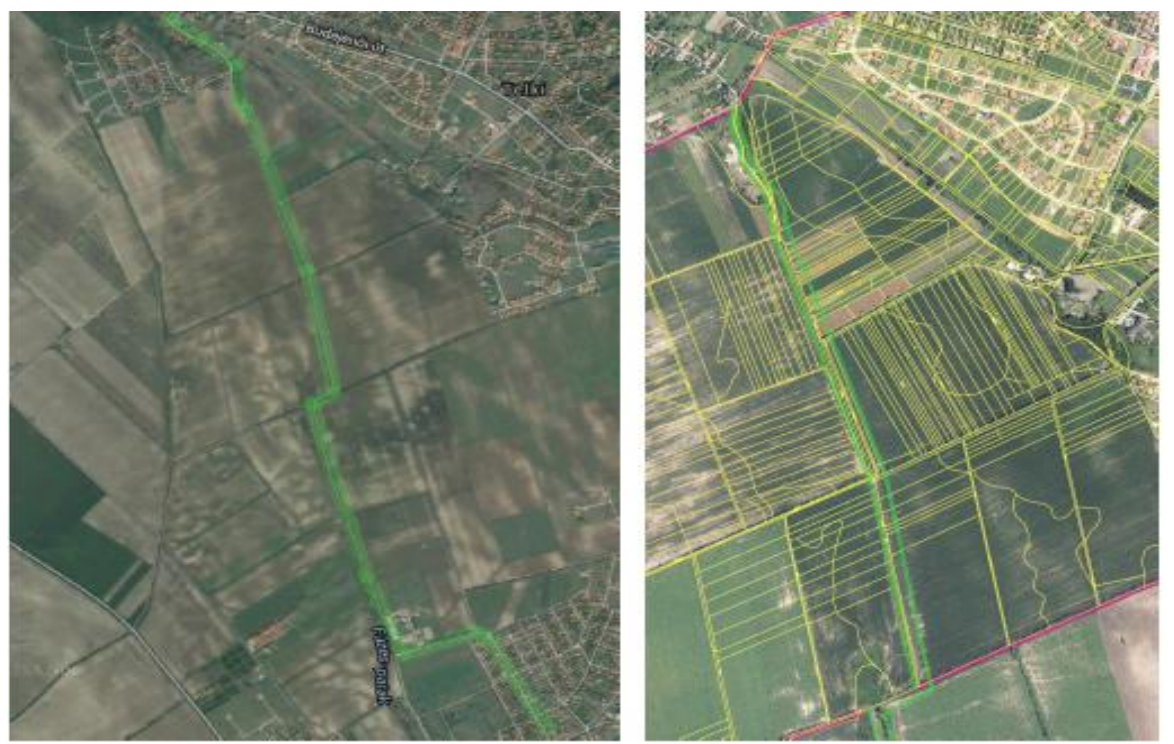

14. ábra: A településközi út légifelvételen (2000), a felső szakasz tulajdonosi helyzetének bemutatásával (saját szerkesztés)

- Az út középső szakaszán a részben megmaradt kettős fasor alapján a régi szekérút szélessége 6 $\mathrm{m}$ volt, a fasorok közötti rész szintén elbozótosodott. Létrejött egy új földút, amely azonban földhivatali bejegyzésre nem került. A középső szakaszon önálló zöldút kialakítása a meglévő kettős fasor kiegészítésével, a fasorok közötti tereprendezéssel, valamint a tulajdonviszonyok megfelelő rendezésével alakítható ki (14.ábra).

— Az út alsó szakasza 10 m széles, kettős fasor között jelenleg is útként használatos. Kerékpáros használatának értékét csökkenti a lovaglás miatt göröngyös útfelszín. Önálló gyalogos- és kerékpáros célt szolgáló zöldút nyomvonal kialakítására az út környezetében lévő Füzes-patak partja alkalmas.

\subsubsection{Tájépítészeti koncepció}

A zöldút-hálózat hierarchikus felépítésü. Alapgondolata: a zöldút "mint egy keringési rendszer köti össze a településeket a környező tájjal" (PRESIDENT COMMISSION, 1987). A Zsámbéki-medencei zöldút fö tengelyét (a föeret) a Békás-patak és néhány mellékpatakja adja, kiegészítve a Budajenő-Páty közötti hagyományos településközi úttal. A mellékerek a föerektől bevezetnek a településközpontokba. A hajszálerek elvezetnek a települések karakteres tájértékeihez. A helyi zöldút a Békás-patak alsó szakaszán keresztül kapcsolódhat a Duna menti kerékpárúthoz, amit országos szintű zöldút lehetőségnek tekintek. 


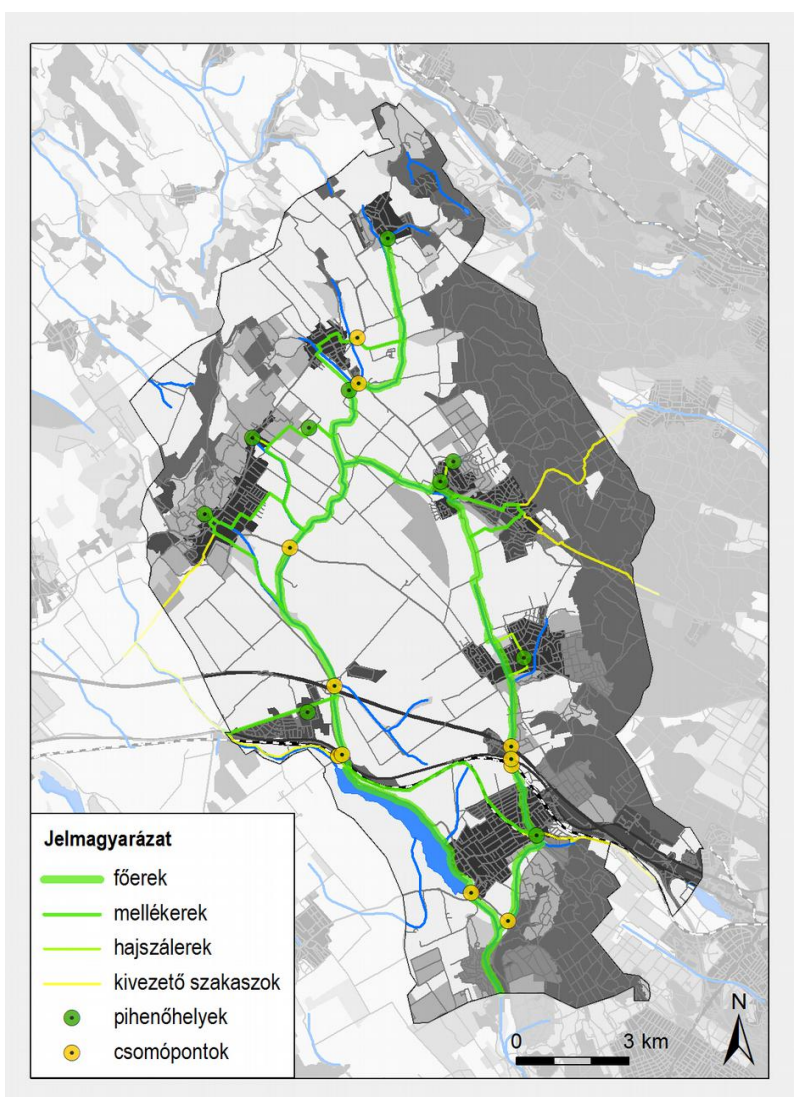

15. ábra: Saját zöldút-hálózat koncepció a Zsámbéki-medencére (saját szerkesztés)

A saját javaslat újszerüségei

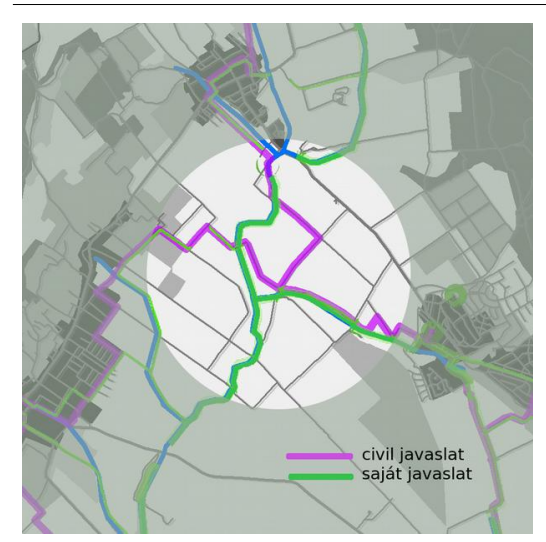

16. ábra: Mezögazdasági úton kijelölt zöldút kiváltása vízparti zöldúttal (saját szerkesztés)
A civil zöldút javaslat meglévő, járható utak összefüggő hálózatában vannak olyan mezőgazdasági utakon vezető fátlan szakaszok, amelyeket saját koncepcióm szerint vízparti zöldúttal javasolok kiváltani. Ez a megoldás tervezési beavatkozást igényel, egyrészt a tulajdonosi viszonyok megváltoztatása, másrészt a vízparti útvonal optimális kialakítása céljából. 


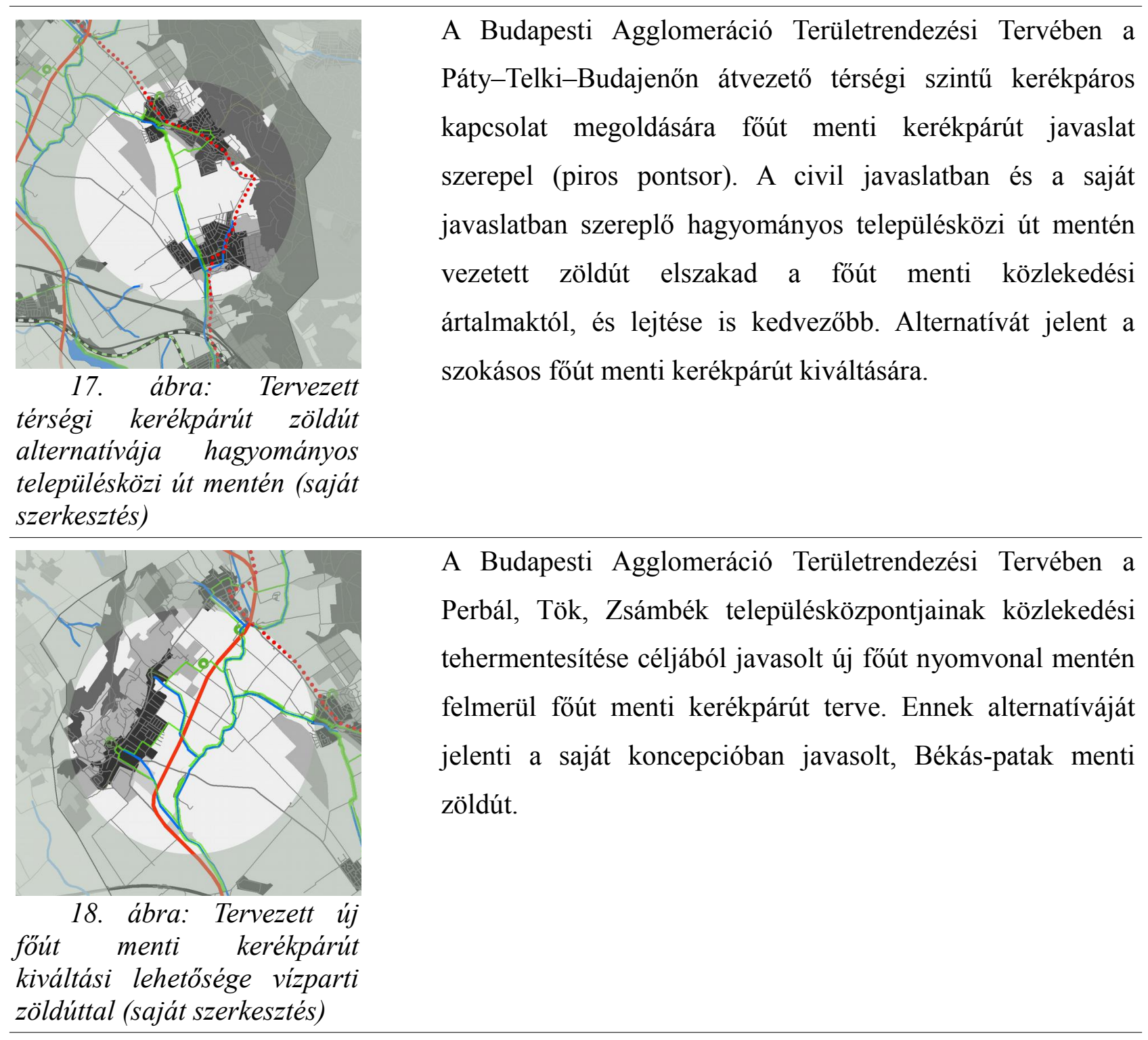

\subsubsection{Illeszkedés a területrendezési tervekhez.}

A térségi övezetképzés lehetősége

"A területi tervezésben az övezeti szabályozás lehetőséget biztosít arra, hogy a különböző szempontból védelemre érdemes vagy területhasználati szempontból eltérően kezelendő területek lehatárolásra kerüljenek, és az így lehatárolt területekre vonatkozóan külön elöírások is meghatározhatók legyenek." (GERZÁNICS, 2013)

"Zöldút kialakitására javasolt térségi övezet" megállapitásának lehetősége

A zöldutak alapvető elemeit (nyomvonal, keresztmetszet, kapcsolódó zöldfelületek, egyéb tárgyi elemek) bemutató 5.1. fejezet alapján a zöldutak területhasználati szempontból változatlan, de a kezelés, illetve a használati módok tekintetében eltérően kezelést igénylő területeknek tekinthetők, 
ezért optimális kialakításukat, fejlesztésüket és fenntartásukat önálló térségi övezet lehatárolása biztosíthatja. A területrendezési tervezéshez kapcsolódó térségi övezetképzés a zöldút-tervezés számára jó tervezési eszköz lehet, mert a zöldutak tervezése a települési szint feletti, térségi tervezést igényel, valamint azért, mert a zöldút-tervezés a területrendezési tervek szerkezeti tervében szereplő területfelhasználási kategóriák megváltoztatása nélkül, az azokon megvalósuló új — rekreációs célú - használatok tervezésére irányul.

\section{"Zöldút kialakitására javasolt térségi övezet" képzésének célja}

Az új térségi övezet képzésének célja elsősorban olyan, tájszerkezeti szempontból értékes tájelemek (vízparti területek, felhagyott vasútvonalak, történelmi útvonalak, mezőgazdasági útként fennmaradt egykori településközi szekérutak stb.) és környezetük megörzése és védelme, amelyek többféle rekreációs használat számára egyaránt vonzó lehetőséget jelentenek. Az övezetképzés célja másodsorban a zöldút kialakítására alkalmas vonalas tájelemek rekreációs lehetőségeinek feltárása és optimális zöldfelületi fejlesztése, amely térségi jelentőségü, hierarchikus rendszert alkotó, rekreációs és ökológiai szempontból egyaránt jelentős szerepű zöldút-hálózatok létrejöttét eredményezheti.

\section{Az övezetképzés lehetséges helye a területrendezési tervezés hierarchiájában}

Tekintettel a területrendezési tervek léptékének törvényi elöírására, a "zöldút kialakítására alkalmas térségi övezet" kijelölése a területrendezési tervezés különféle szintjein, az egyes zöldutak hierarchikus szerepének megfelelően lehetséges. Az országos jelentőségű (elsősorban a fö- és mellékfolyók, nagy tavak, legfőbb történelmi útvonalak mentén stb. kialakítható) zöldutak megjelenhetnek az Országos Területrendezési Terv övezeti tervében. Az országos jelentőségü zöldutakhoz kapcsolható megyei vagy kiemelt térségi jelentőségű (egyes mellékfolyók, patakok, mezőgazdasági útként fennmaradt egykori településközi szekérutak stb. mentén kialakítható) zöldút kialakítására alkalmas övezetek a megyei és a kiemelt térségi tervek övezeti terveiben jelenhetnek meg. Amennyiben az országos, a megyei és a kiemelt térségi tervekben a "zöldút kialakítására alkalmas térségi övezetek" lehatárolása és az övezeti elöírások elfogadásra kerülnek, a térségi övezeti előírások a településrendezési tervezés során érvényesíthetők.

\section{A javasolt övezet gyakorlati bevezetésének szempontjai}

$\mathrm{Az}$ övezet területrendezési tervekben történő bevezetésénél fontos szempont, hogy az övezet kijelölése települési szinten birtok- és telekrendezési feladatokat is jelenthet (például új, közhasználatú utak létesítése vagy meglévő, utak szélesítése mezőgazdasági területeken, patakmeder rendezés stb.). A"zöldút kialakítására alkalmas térségi övezet" megjelenése a 
területrendezési tervekben új -- anyagi háttér biztosítását is igénylő --, térségi és települési szintü szerepvállalást, kötelezettségek vállalását is igényeli (tervezési, megvalósítási, fenntartási feladatok). Az új övezet gyakorlati bevezetésénél - konkrét tervezési területeken - az igények és a lehetőségek felmérése, elemzése szükséges.

\section{A "zöldút kialakitására alkalmas térségi övezet" területére javasolt elöirások}

A javasolt övezet területén érvényesítendő előírások a rekreációs használat számára optimális müszaki-zöldfelületi megoldásoknak és az ökológiai értékek megőrzésének összehangolását szolgálják.

- Az övezet területén biztosítani kell többféle rekreációs használat számára alkalmas utak kialakítását és azok - kerítéssel történő lezárás vagy gépjármü forgalom által meg nem szakított - folyamatosságát.

— Az övezet területét a települési zöldfelületekhez kapcsolódóan kell tervezni, fejleszteni és fenntartani.

— Az övezetbe tartozó terület használatának (rekreációs használat, mezőgazdasági használat) szabályait helyi rendeletben kell megállapítani.

A javasolt térségi övezet kialakitásához szükséges adatok

A javasolt térségi övezet lehatárolása tervezői lehatárolással történhet.

A területi lehatárolások és az elöírások megfogalmazása a következő adatok alapján történhet:

— térségi szerkezeti terv,

— térségi ökológiai hálózat övezeti tervei,

— településrendezési tervek,

— történeti térképek,

- tájrégészeti kutatások eredményei,

- a helyi emlékezet és hagyomány,

— helyszíni bejárások tapasztalatai.

\section{Zöldút kialakitására alkalmas térségi övezet lehatárolása a Zsámbéki-medence területén}

Térségi övezetként a javasolt zöldút-hálózat fő gerincének (fö erének) lehatárolását javasolom. A Zsámbéki-medence területén ennek fő szakasza a Békás-patak mente, a Füzes-patak mente és a Budajenő-Páty közötti, mezőgazdasági útként fennmaradt hagyományos településközi út nyomvonala. Az övezet lehatárolását a patakmedrek, illetve a településközi út tengelyétől 200-200 m-re javasolom. A lehatárolás távolságát a történeti térképek, a topográfiai térképek és a légifotók 
elemzése alapján állapítottam meg annak alapján, hogy az érintett területeken jellemzően 200 m-en belül találhatók olyan meglévő útvonalak, amelyek zöldutak nyomvonalai lehetnek (16. ábra) Az övezeten belül a településrendezési tervek készítése során szükséges

- megkeresni a legmegfelelöbb zöldút nyomvonalat (200 m-en belül meglévő út zöldúttá alakítását vagy új zöldút nyomvonal létesítést);

— elemezni az ökológiai állapotot, meghatározni a lehetséges fejlesztéseket (patak revitalizációt, fásítást stb.);

— meghatározni a zöldfelületi fejlesztési lehetőségeket (tereprendezés, pihenőhely tervezés, tanösvénytervezés stb.);

— szükség szerint rendezni a tulajdonviszonyokat.

Az övezetben kialakításra kerülő utak elsősorban a kerékpározást szolgálnák, másodsorban a gyaloglást (ezt különösen a települések közelében), a lovas útvonalaknak lehetőség szerinti elválasztását meg kell oldani (pl. a patakok "másik" partján)

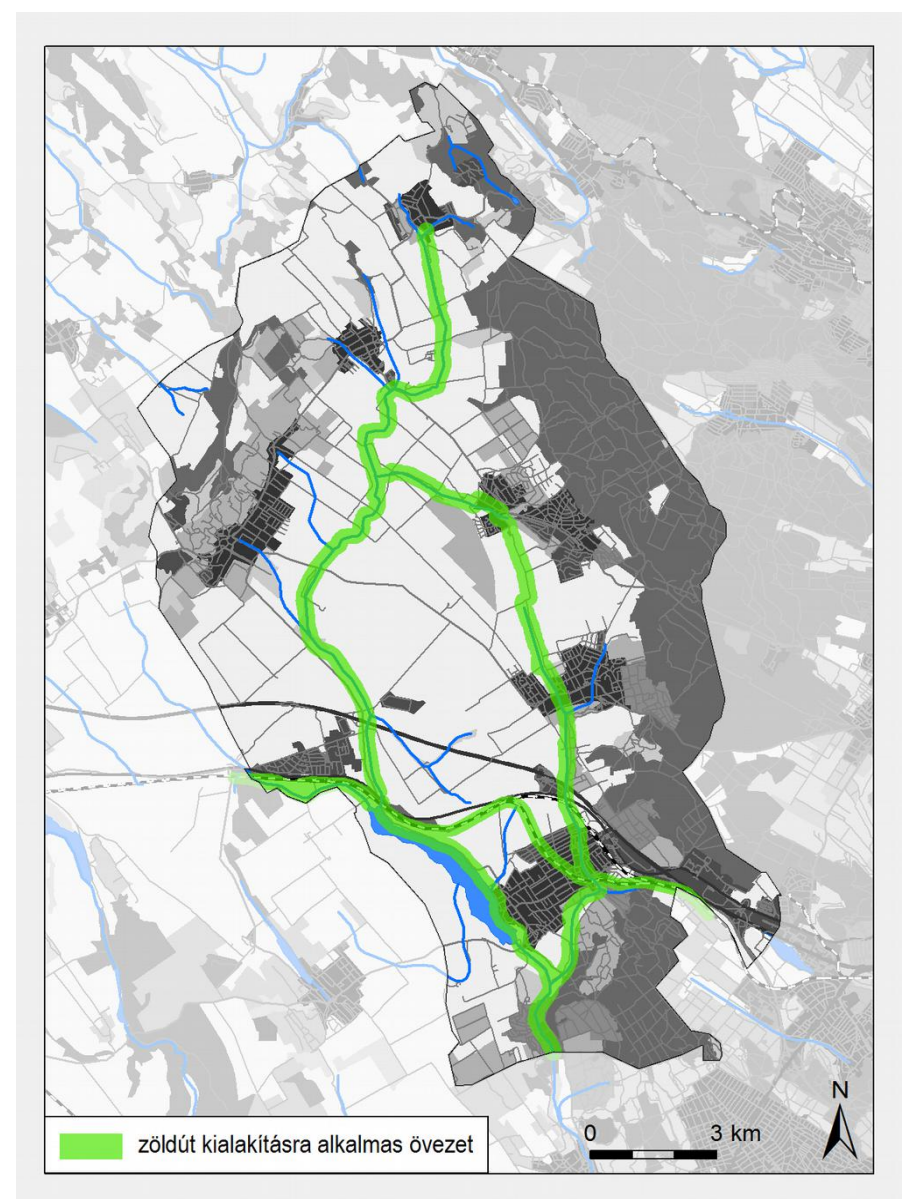

19. ábra: A "zöldút kialakitására javasolt térségi övezet" lehatárolása (saját szerkesztés) 
A zöldút kialakitására alkalmas térségi övezet és az ökológiai folyosó térségi övezet kapcsolata
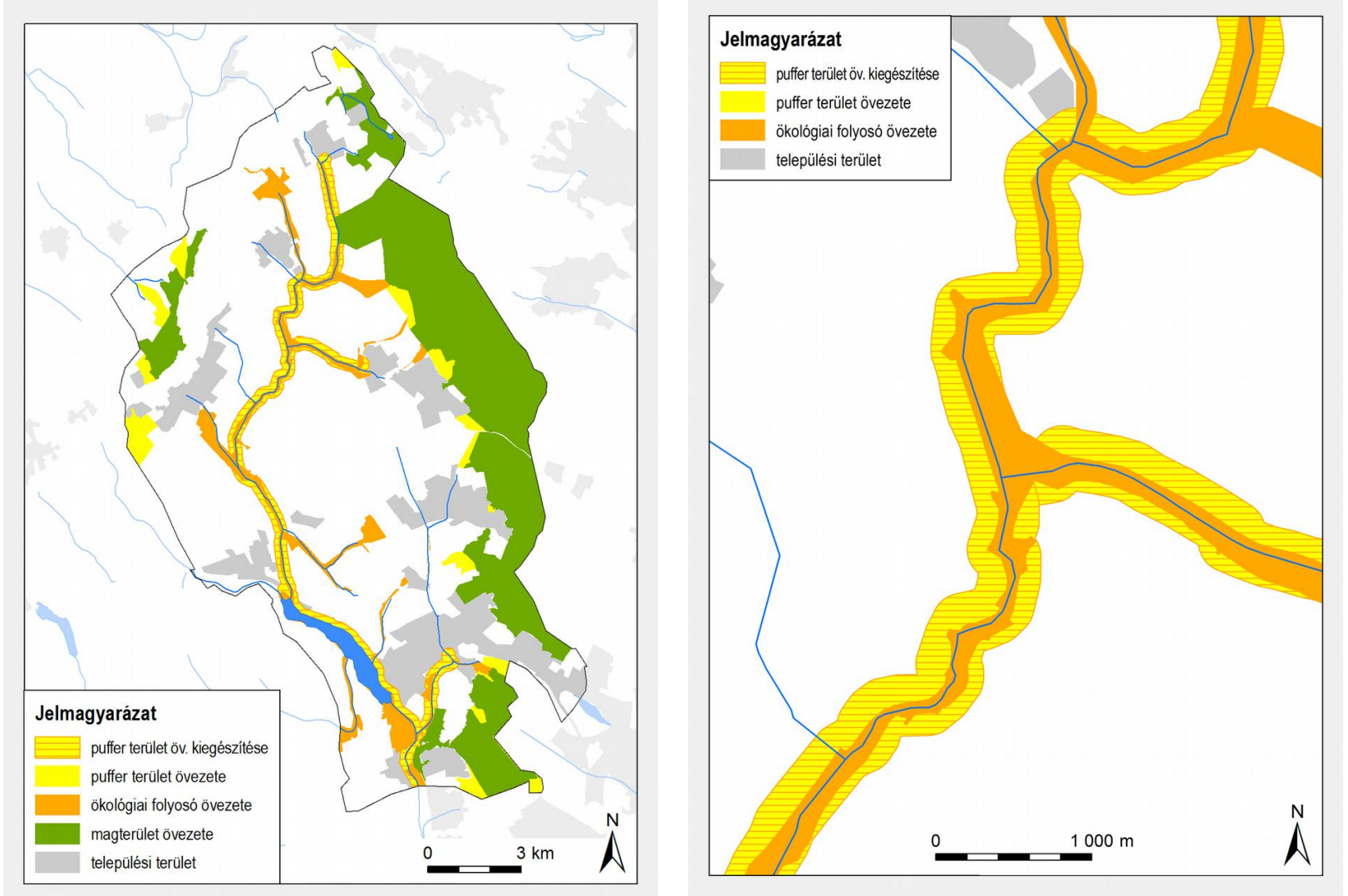

20. ábra: Az 'ökológiai folyosó' és a 'zöldút kialakitására javasolt' térségi övezetek átfedése (saját szerkesztés)

Az ökológiai folyosó térségi övezetével részben átfedő zöldút kialakítására javasolt térségi övezetben ökológiai pufferterületek jöhetnek létre 


\section{MAGYARORSZÁGI ZÖLDÚT-TERVEZÉS ALAPVETŐ METODIKAI ELEMEI}

A magyarországi zöldút-tervezés metodikai megalapozásában alapvető a térbeli kialakítási lehetőségek megállapítása, erre alapozva a zöldutak tájépítészeti szempontú definíciójának megalkotása, valamint a zöldút-tervezés lehetséges helyének meghatározása területrendezési tervezésben

\subsection{Zöldutak térbeli kialakítása}

A zöldutak térbeli kialakítási lehetőségeit a zöldutak alkotóelemei, a zöldutak egyéb rekreációs és ökológiai szerepü tájelemekkel való kapcsolata és a zöldutak beépített területekkel való kapcsolata határozza meg.

\subsubsection{A zöldút elemei}

\section{Nyomvonal}

A nyomvonal a zöldút alapvető, meghatározó jelentőségü eleme. Az olmstedi modell alapján az első számú lehetőséget a folyók és patakok partjai jelentik, amelyeket a magyarországi adottságoknak megfelelöen a nagyobb tavaink vízpartjaival egészíthetünk ki. A klasszikus - amerikai - zöldutak történetét tekintve következő lehetőséget a felhagyott vasúti nyomvonalak jelentik. A hazai átfogó, hosszútávú közlekedésfejlesztési tervekre való tekintettel - melyben a vasúti közlekedés megtartásának és fejlesztésének környezetvédelmi szempontból is támogatott fejlesztése prioritást kap - ezt a lehetőséget annyiban kell finomítani, hogy zöldutak számára elsősorban azok a felhagyott vasúti nyomvonalak (és kapcsolódó területek) alkalmasak, amelyeken a forgalom visszaállítása, illetve más - gazdaságilag nagyságrendekkel előnyösebb hasznosítása - nem merül fel, vagy megszüntetett vasúti közlekedés kiváltása tömegközlekedéssel megoldott és/vagy a vasúti nyomvonalon már kerékpárút épült. Kifejezetten jó lehetőséget jelentenek a hatvanas évek vasúti nyomvonal-korszerüsítései következtében megszünt szakaszok. Egyes vasútvonalak környezete elegendő terület rendelkezésre állása esetén - szintén jó lehetőséget jelent zöldutak létesítésére.

A klasszikus zöldút lehetőségek mellett kutatásom meghatározó részét jelenti a sajátos magyarországi zöldút nyomvonal lehetőségek feltárása. A Zsámbéki-medence, mint kutatási mintaterület elemzése során rámutattam a mezőgazdasági útként fennmaradt hagyományos településközi utak zöldúttá fejlesztésének lehetőségére. További sajátos lehetőségeket jelenthetnek egyes különleges adottságok, mint a Magyarország nyugati határvonalán - az egykori "vasfüggöny" területén - kialakult zöldsáv, melynek többféle célú kirándulási hasznosítására európai szintü program, a 'European Greenbelt Program' épül. 


\section{Keresztmetszet}

A tájépítészeti szakirodalomban javasolt keresztmetszeti megoldások a zöldutak lényeges szerepét és tulajdonságait szemléltetik: mivel a kirándulási célra különösen jó adottságokat jelentő nyomvonalak többféle rekreációs használatra egyaránt megfelelők lehetnek, elegendő hely biztosítása esetén gyalogos, kerékpáros és lovas funkciójú sávok együttesen elhelyezhetők bennük. A különféle funkciók elhelyezése az adottságoktól függően lehetséges egy, vegyes használatra alkalmas sávval, vagy a különböző használatok számára elválasztott rendszerben kialakítva, több önálló sávval.

\section{Csomópontok}

Zöldutak és más - elsősorban közúti és vasúti - útvonalak megfelelő, akár külön szintű csomóponti kialakítására az Olmsted-féle 'Emerald Necklace' müszaki megoldásai szolgálnak például. Az olmstedi zöldút modell egyik legfőbb sajátossága a zöldutak folyamatossága, vagyis a megszakítás nélküli rekreációs szerepű úthálózat kialakítása. A csomóponttervezés kérdése különösen fontos települési elkerülőutak és gyorsforgalmi utak nyomvonalának tervezésénél annak érdekében, hogy a zöldutak balesetveszély nélkül használhatók legyenek.

\section{Kapcsolódó zöldfelületek}

Az olmstedi modellt tekintve a zöldút-tervezés hangsúlyos része a zöldútvonal menti zöldfelületek összekapcsolása a zöldút nyomvonalával. Ez azt jelenti, hogy a zöldút, mint tájelem egyrészt a változó szélességủ útból, másrészt az úthoz közvetlenül kapcsolódó, vonalas és területi kiterjedésű zöldfelületekből áll. Ezért a zöldutak tervezése, fejlesztése, fenntartása érdekében az egyes zöldutak területét az erre alkalmas léptékben és ennek értelmében kell lehatárolni.

\section{Egyéb tárgyi elemek}

A zöldutak biztonságos és kényelmes használata, valamint a táj bemutatása céljából tárgyi elemek elhelyezése is szükséges. A zöldutak területén általánosan szükséges tárgyi elemek - melyek körét az egyes zöldutak létesítésének igényei, lehetőségei szerint bővíteni lehet - a következők:

— terepi építmények: hidak, átereszek,

— útjelző és tájékozódást segítő tárgyak: útjelző táblák és oszlopok, települések földrajzi irányát és távolságát jelző oszlopok,

— pihenést szolgáló tárgyak: padok, esőbeállók, ivókutak, rajztáblák stb.,

— ismeretterjesztést szolgáló tárgyak: ismeretterjesztő táblák, távcső, madárles stb.,

— forgalomszámlálást szolgáló elemek: forgalomszámláló szerkezet. 


\subsubsection{Zöldutak alapvető kialakítási lehetőségei a rekreációs és az ökológiai szerepü tájelemekkel összefüggésben}

Az ökológiai szempontból értékes ökológiai és zöldfolyosók, valamint a rekreációs szempontból értékes útvonalak önmagukban még nem nevezhetők zöldútnak. Zöldúttá akkor válhatnak, ha az ökológiai és a rekreációs funkció egyszerre jelenik meg, és a zöldút modell meghatározó térbeli jellemzőit tartalmazva alkot tájszerkezeti jelentőségü teret a tájban.

A magyarországi táji adottságok figyelembevételével a jelentős rekreációs és ökológiai szerepet egyaránt betöltő zöldutak létesítésének négy alapvető térbeli lehetőségét határozom meg:

— meglévő, jelentős zöldfelülettel rendelkező rekreációs útvonalak zöldúttá alakítása,

— meglévő ökológiai vagy zöldfolyosók zöldúttá alakítása rekreációs célú fejlesztéssel,

— meglévő rekreációs szerepű útvonalak zöldúttá alakítása zöldfelületi fejlesztéssel,

— új, jelentős zöldfelülettel rendelkező rekreációs útvonalak tervezése a zöldút modell alkalmazásával. (18. ábra)

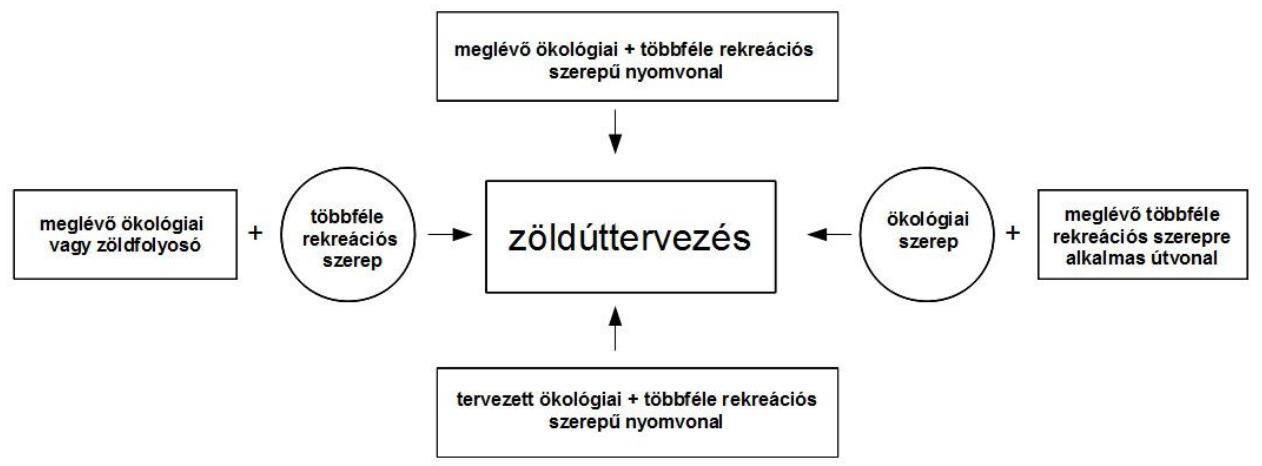

21. ábra: Zöldutak alapvetö kialakitási lehetöségei a rekreációs és az ökológiai szerepü tájelemekkel összefüggésben (saját szerkesztés)

\subsubsection{Zöldutak kapcsolódása a települések beépített területeihez}

A zöldutak a települések térbeli összekapcsolását tekintve jelennek meg újszerü tájelemként. A települések közötti új térkapcsolat elsősorban a települések külterületeit érinti. A zöldutak a települések belterületein a térbeli adottságoknak megfelelően különféle meglévő vagy tervezett, illetve tervezhetö útvonalakban - gyalogos és kerékpáros útvonalak, vegyes forgalmú utcák, sétányok - folytatódhatnak. A térségi szintű zöldút-tervezéshez tartozó feladatként jelenik .meg a zöldutaknak a települések beépített területeit elérő ki- és belépési pontjainak meghatározása, amelyben elsősorban az optimális külterületi nyomvonal és a lehetséges belterületi útkapcsolatok összehangolása játszik szerepet. Ehhez kapcsolódóan kell meghatározni a ki- és belépő pontok 
közötti útvonalat a kapcsolódó zöldfelületekkel együtt.

Kedvező adottságok esetén - pl. patak- és folyópartok menti területek, felhagyott vasúti nyomvonalak vagy egyéb, zöldfelületként hasznosítható területsávok megléte esetén - a települések belterületein is tervezhetők zöldút szakaszok az olmstedi modell alkalmazásával.

\subsubsection{A javasolt magyarországi zöldút-hálózat elvi struktúrája}

A zöldút modell térségi és országos szintü kiterjesztésével az egész országot behálózó zöldúthálózat tervezhető és alakítható ki. A zöldút-hálózat elvi struktúrája a a területrendezési tervek hierarchikus rendjét követi, és a müszaki infrastruktúra hálózatokhoz hasonló fö- és mellékágakból álló rendszert alkothat. A zöldutak gerinchálózatát a vízparti területek, a zöldút fejlesztésre alkalmas felhagyott vasúti nyomvonalak és egyéb, országos szintű zöldút nyomvonalak (pl. a határ menti egykori "vasfüggöny" nyomvonala) alkothatják. A gerinchálózathoz kapcsolódó mellékágakat a térségi szerepet betöltő mellékágak alkothatják, elsősorban a patakok menti területek és egyes hagyományos településközi utak zöldúttá alakításával. A térségi szintű mellékágakhoz helyi szintü zöldutak és/vagy egyéb rekreációs útvonalak kapcsolódhatnak. A hálózati struktúra hajszálereit további egyéb közhasználatú, rekreációs szerepre is alkalmas útvonalak - belterületi utcák, gyaloglásra, kerékpározásra használható mezőgazdasági és erdészeti utak - alkothatják.

\subsection{A zöldút fogalom tájépítészeti szempontú meghatározása}

A zöldutak létesítése az USA-ban helyi kezdeményezésekkel indult el. A zöldút elnevezés egy vízparti sétaút, a 'Santa Clara Greenway' létrehozásával született meg. Az első zöldút definíciók a zöldút fogalom tisztázása, az első zöldút mintájára létesített zöldutak csoportosítása, illetve a zöldutak országos méretü kiterjesztése céljából születettek meg (PRESIDENT COMMISSION, 1989, LiTTLE, 1990). A tájépítészeti szakirodalomban a zöldút definíciók a zöldutak, illetve zöldúthálózatok helyi, térségi és országos szintü, összehangolt, komplex tájépítészeti tervezéséhez kapcsolódóan jelentek meg (FABOS, 1995).

Jelenleg Magyarországon hasonló a helyzet az amerikai zöldutak tájépítészeti tervezésének kezdetén Julius Gy. Fabos professzor által "a zöldúttípusok kusza helyzetétől a jól meghatározott zöldút-tervezés korszakáig" tartó átmeneti időszak állapotához. Csemez Attila és társai zöldúttervezésre irányuló tanulmányával (CSEMEZ ET AL, 2000) megkezdődött a zöldút-tervezésre irányuló tájépítészeti kutató munka, a zöldút-tervezés tájépítészeti hallgatói gyakorlatok és diplomatervek készítésével az oktatói munka részévé vált. Az egyetemi kutató-oktatómunka mellett helyi társadalmi kezdeményezéssel is történnek zöldút kijelölések, az Európai Zöldutak Szövetségének iránymutatásai szerint. A zöldút fogalom jelentéstartalma sokféle, a hazai 
szakirodalomban és a gyakorlati életben egyelőre nem egyértelmü.

Jelen dolgozatban a zöldút definíció tervezésbe illeszthető meghatározására vállalkozom annak érdekében, hogy a zöldút-tervezés a hazai terület- és településrendezési tervezésben megjelenhessen, és ezáltal helyi, térségi és országos szinten összehangolt, komplex tervezési folyamattá válhasson.

\subsubsection{Kiindulási alapok}

A zöldút hazai terület- és településrendezési tervezésbe illeszthető definíciójának megalkotásához a tájépítészeti szakirodalomban meghatározó zöldút definíciók jelentik az alapot.

\section{'President Commission' (1987)}

Az országos szintü zöldút-hálózatok elnöki határozatban szereplő megfogalmazása a tájépítészeti szakirodalomban a zöldút definíciók alapvető előzményeként szerepel. A szemléletes és tömör kifejezésmód a magyarországi terület- és településrendezési tervezési rendszerbe illeszthető zöldút fogalom megalkotását is segíti.

"A zöldutak élő hálózata... elvezeti az embereket a környezetükben lévő szabadterekhez, összeköti az amerikai táj vidéki térségeit és szabadtereit... felfüzi a városokat és a vidéki területeket, mint egy óriási keringési rendszer. ${ }^{11 "}$

\section{Fabos-féle definició (1995)}

A Julius Gy. Fabos által vezetett kutatások során megfogalmazódott az első tájépítészeti zöldút definíció, amelyben hangsúlyos szerepet kap a zöldutak vízfelületekhez való kapcsolódásának és a zöldutak komplex - rekreációs, ökológiai és kulturális - szerepének megállapítása.

"A zöldutak egyrészt lehetnek ökológiai szempontból meghatározó jelentőségű folyosók és természetes rendszerek, másrészt rekreációs zöldutak, amelyek területe a használók számára útvonalakat és vizi kapcsolatot, valamint vízhez kapcsolódó rekreációs lehetőségeket biztosít, harmadrészt olyan zöldutak, amelyek a történelmi örökség és a kulturális értékek védelmét biztosítják. A zöldutak gyakran többcélú folyosók, amelyek mindhárom szerepet betöltik. ${ }^{12}$

\section{Ahern-féle definició (1996)}

A Jack Ahern által alkotott zöldút definíció a Fabos-féle definíció általánosabb kiterjesztésének

11 A living network of greenways ...to provide people with access to open spaces close to where they live, and to link together the rural and open spaces in the American landscape...threading throught cities and countryside's like a giant circulation system ( President's Commission on American Outdoors for the United States, 1987)

12 First, greenways are: ecologically significant corridors and natural systems; second, recreational greenways, where users find a network of trails and water link land and water-based recreational sites and areas; third, greenways which provide historical heritage and cultural values. Greenways are often multi-purpose corridors providing all three functions and benefits (Fábos, 1995). 
tekinthető. A zöldutak konkrét területi megjelölése helyett a zöldutak lineáris jellegét hangsúlyozza. A definíció figyelembe veszi a felhagyott vasúti nyomvonalak mentén és egyéb, zöldutak számára alkalmas területeken történt zöldútlétesítéseket.

"A zöldutak a táj lineáris elemekböl álló hálózatai, amelyeket többféle - ökológiai, rekreációs, kulturális, esztétikai és egyéb - céllal, a fenntartható fejlődés elvének megfelelően terveznek és tartanak fenn. ${ }^{13}$

\section{Turner-féle definíció (1995)}

Tom Turner a zöldút fogalmat szintén kiterjeszti. Definíciójavaslatát a városok beépített területén meglévő és tervezhető különféle, rekreációs szerepet betöltő útvonalak közös vonásának kiemelésével alkotja meg: "A zöldút ... egy útvonal, amely környezeti szempontból megfelelö"14. Ebben a megfogalmazásban a 'környezeti' szempont nem környezetvédelmi, hanem a szabadtértervezésben használt értelemben - tervezett szabadtér - szerepel.

\section{Csemez és társai-féle definició (2000)}

A Csemez Attila és társai tanulmányában szereplő zöldút definíció alapja a Fabos-féle definíció. A definícióban a szerzők meghatározzák a zöldutak kialakításának lehetséges területeit. Az útvonalakhoz kapcsolódó zöldfelületek összességét a zöldúthoz tartozó területeknek tekintik. A rekreációs funkciót a zöldutak egyik lehetséges szerepeként határozzák meg.

"A zöldút (zöldfolyosó) valamilyen vonalas jellegü természeti képződmény (vízfolyás, természetes folyosó, hegygerinc) vagy emberi hatás által kialakított infrastruktúra létesítmény (út, vasút, csatorna) mellett létrejött szárazföldi zöldfelületek összessége, amely parkokat, zöldterületeket, természetvédelmi területeket kapcsol össze és rekreációs funkciója is lehet" (CSEMEZ ET AL 2000).

\section{Almási-féle definíció (2007)}

Almási Balázs doktori értekezésében a zöldutakat a zöldhálózat (= meghatározó növénystruktúrával rendelkező közhasználatú térrendszer) lineáris elemeinek tekinti. A zöldút fogalom meghatározása a Turner-féle zöldút értelmezéshez közelít. A definíció a zöldutak funkcióit az Ahern-féle meghatározás alapján tartalmazza.

\subsubsection{Civil szervezetek által megfogalmazott zöldút definíciók}

13 Greenways are networks of land containing linear elements that are planned, designed and managed for multiple purposes including ecological, recreational, cultural, aesthetic or other purposes compatible with the concept of sustainable land use. (Ahern, 1996)

14 A simple definítion of a greenway, which takes on board the extended current usage of the term, could be 'a route which is good from an environmental point of view'. (Turner, 1995) 
A tájépítészeti szakirodalomban szereplő zöldút definíciók mellett európai civil szervezetek által megfogalmazott zöldút definíciók is ismertek. E definíciók az amerikai zöldút-tervezésben használt fogalom-meghatározásokra épülnek, azokat a megvalósíthatóság céljából értelmezik és kiegészítik a zöldutak lehetséges szerepeinek meghatározásával.

\section{Európai Zöldutak Szövetsége definíciója (2000)}

A zöldutak olyan közlekedési útvonalak, amelyek a nemmotoros kirándulások számára vannak fenntartva, és amelyek fejlesztése egységes módszerrel történik, és amelyek növelik a környező terület ökológiai értékét az életminőséget. Ezeknak az utaknak megfelelő szélességi, lejtési és útfelszínkialakítási minőséget kell biztosítaniuk annak érdekében, hogy biztosítsák mind a felhasználóbarátságot mind az alacsony kockázatot a különböző képességű használók számára. ${ }^{15}$

\section{Közép-Európai Zöldutak Szövetsége definiciója (2006)}

A zöldutak olyan többfunkciós útvonalak, melyeket a nem motoros közlekedés céljára alakítanak ki. Lehetnek zöld folyosók, történelmi kereskedelmi útvonalak, folyók és vasutak mentén vezető ösvények, utak. A zöldutakat helyi emberek múködtetik, azzal a céllal, hogy támogassák a fenntartható fejlődést és az egészséges életmódot. A zöldutak keretet biztosítanak a közösségen alapuló kezdeményezéseknek és a természetvédelemhez, kulturális örökségvédelemhez, fenntartható turizmushoz és a nem motorizált közlekedéshez kapcsolódó projekteknek. A zöldutak kezdeményezői törekszenek arra, hogy kielégítsék a helyiek és a látogatók igényeit és hozzájáruljanak a helyi gazdaság megerősítéséhez. ${ }^{16}$

\section{Budai és társai-féle definició (2005)}

A zöldutak (Greenways) olyan természeti folyosók, útvonalak, melyeket ökológiai funkciójuk figyelembevételével használhatunk sportra, turizmusra, kikapcsolódásra és mindennapi közlekedésre. Hasznosak a természetvédelem, a kulturális örökségvédelem és az egészségmegőrzés szempontjából. Segítik a helyi gazdaság fejlődését és a helyi közösségek megerősödését (BUDAI ET $\mathrm{AL}, 2005)$.

15 Greenways are communication routes reserved exclusively for non-motorised journeys, developed in an integrated manner which enhances both the environment and quality of life of the surrounding area. These routes should meet satisfactory standards of width, gradient and surface condition to ensure that they are both user-friendly and lowrisk for users of all abilities. (Lille Declaration, European Greenways Association, $12^{\text {th }}$ September 2000).

16 Greenways are multifunctional trails, developed in both urban and rural areas, for non-motorized users typically leading along linear green corridors, historic trade routes, rivers and railways. They are managed by local people in order to encourage sustainable development and healthy lifestyle. Greenways provide a framework for communitybased initiatives and projects related to nature conservation, cultural heritage preservation, sustainable tourism and mobility. Greenways seek to address needs of locals and visitors and to provide a positive contribution to the local economy.(Sopron Declaration, Environmental Partnership for Sustainable Development, $1^{\text {st }}$ July 2006). 


\section{Molnár-féle civil zöldút definíció (2014)}

A civil zöldút mozgalmak által használt zöldút fogalom jelentéstartalmát jól tükrözi a "Turistaúthálózat és jelzésrendszer" című szakmai kiadványban Molnár András által megfogalmazott zöldút definíció: "A civil zöldutak közösségi kezdeményezésű helyi jellegü útvonalak, úthálózatok, nem mindig, illetve nem kizárólag gyalogos jármód számára. Céljuk a szemléletformálás, a közösségépítés, a helyi "zöld" közlekedés elősegítése, a kapcsolódó helyi értékekre, olykor termékekre való figyelem felhívása. Ezek a Zöldutak Módszertani Egyesület (ZÖME) által koordinált útvonalak" (MOLNÁR, 2014).

\subsubsection{A hazai területrendezési és településrendezési tervezésbe illeszthető zöldút definíció}

\section{A definícióalkotás célja}

A magyarországi területrendezési és településrendezési tervezésbe illeszthető zöldút fogalom megalkotásának célja a zöldút sajátos térbeli jellemzőinek egyértelmű megfogalmazása annak érdekében, hogy a zöldút a tervezési folyamatokban önállóan tervezhető, fejleszthető elemként térségi és országos szinten önálló hálózatként - szerepelhessen.

\section{Definícióalkotás szempontok}

A definícióalkotás során arra törekedtem, hogy a definíció

— alapját a tájépítészeti szakirodalomban meghatározó jelentőségü zöldút definíciók jelentsék;

— tartalmában jussanak kifejezésre az olmstedi zöldút modell jellemzői;

— egy adott tervezési terület sajátos táji adottságaihoz és rekreációs igényeihez illeszkedő országos, térségi és helyi szintü tervezést tegyen lehetővé;

— tükrözze a zöldutak sajátos vonásait az egyéb rekreációs útvonalakhoz (turistautak, kerékpárutak, lovas útvonalak), illetve az ökológiai folyosó fogalmához képest.

\section{Az általam javasolt zöldút definíció}

A zöldút többféle rekreációs használatra tervezett út, amely a kapcsolódó zöldfelületekkel együtt térségi szintü, hierarchikus hálózatot alkot. A zöldutak létesítésének fó területei vízpartok, felhagyott vasúti nyomvonalak, történelmi útvonalak, hagyományos településközi utak és egyéb sajátos, rekreációs és ökológiai szerep betöltésére egyaránt alkalmas vonalas tájelemek.

\section{A javasolt definíció tartalmának értelmezése}

A javasolt definíció értelmében a zöldút

— térségi jelentőségü, mert térségü jelentőségü tájelemek mentén létesíthető; 
— legalább kétféle rekreációs használat számára alkalmas, mert olyan nyomvonalakon létesíthető, amelyek többféle kirándulási forma számára egyaránt kedvezőek;

- a motoros közlekedéstől elválasztott útvonal, tehát motoros közlekedéstől való térbeli elválasztása tervezési feladatot jelent;

— a kapcsolódó zöldfelületekkel és tájértékekkel összefüggő hálózatot alkot, mert a zöldúttervezése az útvonal kialakítás mellett az útvonalhoz kapcsolható rekreációs és/vagy ökológiai szerepü területek és tájértékek megőrzését és fejlesztését is jelenti;

- létesítésére alkalmas területek meghatározása a zöldút fogalom egyértelmü értelmezését segíti.

\section{A definicióalkotási szempontok teljesülése}

A definícióalkotás során a kiindulási szempontok érvényesültek, mert

- a definíció alapját a tájépítészeti szakirodalomban meghatározó definíciók (President Commission, Fabos, Ahern) alkotják;

— a definícióban az olmstedi zöldút modell jellemzői kifejezésre jutnak, mert a zöldutak meghatározása az útvonalakhoz kapcsolódó zöldfelületekkel és tájelemekkel együtt történik;

- a definíció egy adott tervezési terület sajátos táji adottságaihoz és rekreációs igényeihez illeszkedő országos, térségi és helyi szintü tervezést tesz lehetővé, mert nem határozza meg a zöldutak konkrét müszaki mutatóit, hanem a kialakítás elvére teszi a hemgsúlyt;

— a definíció tükrözi a zöldutak sajátos vonásait az egyéb rekreációs útvonalakhoz (turistautak, kerékpárutak, lovas útvonalak) képest, mert rögzíti, hogy a zöldutak többféle kirándulási forma számára alkalmasak, tervezési feladatnak tekinti a zöldutak motoros közlekedéstől való térbeli elválasztását, és meghatározza a zöldutak létesítésének lehetséges területeit.

\subsubsection{A javasolt zöldút fogalom és a zöldúttal rokon fogalmak kapcsolata}

A zöldút fogalom értelmezése az ökológiai- és a zöldfolyosókkal összefüggésben

Az ökológiai- és a zöldfolyosók ökológiai szempontok szerint lehatárolt területek, amelyek megőrzését és fejlesztési lehetőségeit a növényi- és állati élőhely biztosítás szempontjai, valamint a génmegőrzés és a génáramlás ökológiai törvényszerüségei határozzák meg. Az ökológiai folyosók a természetes élővilág maradványfoltjai, a zöldfolyosók emberi tevékenységgel létrehozott, ökológiai szerepet betöltő zöldfelületek. Zöldutak akkor létesíthetők ökológiai- és zöldfolyosók területein, ha a zöldutak tervezett rekreációs funkciói összehangolhatók az élőhelyfenntartás ökológiai szempontjaival. Az ökológiai folyosók a területrendezési tervezésben övezeti kategóriaként, az ökológiai hálózat részeként megjelennek. A zöldutak kijelölésének, illetve tervezésének egyelőre 
nincs müszaki-jogi háttere. Kutatásommal a zöldút fogalom müszaki-jogi környezetbe illesztésének megalapozását kívánom elősegíteni.

\section{A zöldút fogalom értelmezése a turistautakkal összefüggésben}

A turistautak a gyalogos kirándulások számára használható útvonalak, amelyek bel- és külterületen, köz- és magánterületen, mezőgazdasági és erdőterületen, bármilyen más úttípussal egy nyomvonalon (kivéve autópálya, autóút) vezethetnek. Kijelölésük feltételeit és módját 2009. évi erdőtörvény határozza meg.

A zöldút-tervezése többféle rekreációs funkció megfelelő térbeli biztosítására irányul. Zöldút és turistaút tervezése közös feladatként jelentkezhet, ha egy tervezett zöldút nyomvonala egybeesik egy meglévő turistaútvonallal, mert az adott nyomvonal más rekreációs használatra (kerékpározás, lovaglás) is alkalmas (például egy - országos vagy térségi jelentőségű - vízparti turistaút nyomvonalán kerékpárútvonal tervezése igényként felmerül). Zöldút és turistaút közös tervezése abban az esetben is felmerülhet, ha egy adott területen nincs kijelölt turistaút, és a tervezett zöldút nyomvonala a turistaút hálózatba illeszthető. Javaslataim alapján tehát gyalogos kirándulást szolgáló turistautak kijelölhetők többfunkciós zöldutak nyomvonalán is. Gyalogos turistaút és zöldút közös tervezéssel történő kialakítása a zöldút javasolt definíciójának megfelelően (kapcsolódó zöldfelületek és tájelemek tervezésével együtt) történhet.

\section{A zöldút fogalom értelmezése a kerékpárutakkal összefüggésben}

Kerékpárutak tervezését az 1988. évi közúti közlekedésről szóló törvény, az arra épülő 93/2012. évi kormányrendelet, valamint ezen jogszabályi előírásokra épülő müszaki előírások és tervezési útmutatók határozzák meg. Az országos és a térségi kerékpárutak nyomvonalai a területrendezési tervezés országos és térségi szintü terveiben is megjelennek.

A zöldút-tervezés a kerékpárút tervezéssel közös feladatként jelentkezhet, ha egy tervezett zöldút nyomvonala egybeesik egy meglévő vagy tervezett kerékpárúttal, mert az adott nyomvonal más rekreációs használatra (gyaloglás, lovaglás) is alkalmas (például egy - térségi jelentőségü kerékpárút nyomvonalán gyalogos vagy lovas használat igénye is felmerül). Kerékpárút és zöldút közös tervezéssel történő kialakítása a zöldút javasolt definíciójának megfelelően (kapcsolódó zöldfelületek és tájelemek tervezésével együtt) történhet.

\section{A zöldút fogalom értelmezése a zöldhálózattal összefüggésben}

A zöldhálózat az egyetemi kutatás-oktatás gyakorlatában a zöldfelületi rendszerek tervezéséhez és a szabadtértervezéshez kapcsolódó fogalom: meghatározó növénystruktúrával rendelkező közhasználatú térrendszer. A zöldutaknak a zöldhálózatok lineáris elemeiként való értelmezését 
finomításra javaslom. Az általam javasolt zöldút definíció szerint a zöldutak a zöldhálózat azon lineáris - de az útvonalakhoz kapcsolódó zöldfelületekkel együtt tervezendő - elemeiként értelmezhetők, amelyek térségi jelentőségüek, és legalább kétféle rekreációs használatra alkalmasak. A zöldutak és a zöldhálózat egyéb lineáris elemeinek tervezését célszerü összehangolni.

\section{A definícióból következö térbeli sajátosságok}

- A zöldutak lineáris útvonalakból és az útvonalakhoz kapcsolódó, rekreációs és ökológiai szerepet egyaránt betöltő zöldfelületekből állnak, tehát nem csak lineáris elemek. Ez az olmstedi modell alapvető sajátossága.

- A beépített területeken a meglévő és a tervezett településszerkezettől függően a zöldút folytatódhat gyalogos, kerékpáros, esetleg lovas útvonalakban vagy vegyes használatú sétányban. Lényeges a kapcsolódási pontok illeszkedése.

- A zöldutak szélességi mérete nem egységes, az adott terület táji adottságaitól függően határozható meg. A zöldutak tervezhető szélességétől függően a különféle kirándulási útvonalak lehetnek vegyes használatúak vagy elválasztott rendszerủek.

— A közutaktól való térbeli elválasztás a zöldutak alapvető jellemzője.

A definíció szerinti zöldút-tervezési következmények

- A zöldutak tájépítészeti tervezése a térségi szintű és a települési szintü tervezésük összehangolásával lehetséges.

- A zöldutak tervezéséhez hozzátartozik az útvonalak menti fásítás tervezése és az útvonalakhoz kapcsolódó zöldfelületek tervezése.

\section{Kapcsolódó fogalmak értelmezése és finomitása}

A tájépítészeti tervezés és a kapcsolódó szakterületi tervezések számára is egyértelmü fogalomhasználat érdekében célszerü megkülönböztetni a koncepciót tükröző fogalmakat (zöldfelület, zöldfelületi rendszer, zöldhálózat), az önálló területfelhasználási kategóriaként vagy övezetként megjelenő fogalmakat (zöldterület, mezőgazdasági terület, ökológiai folyosó stb.) az ökológiai fogalmakat (ökológiai folyosó, zöldfolyosó, valamint az EU szóhasználatában szereplő fogalmakat (zöld infrastruktúra) és az egyéb előforduló szakkifejezéseket.

\subsubsection{A zöldút, valamint az ökológiai és a zöldfolyosó fogalmak kapcsolata}

A zöldút fogalom világos értelmezhetősége érdekében javasolom az ökológiai - és zöldfolyosó fogalmak ökológiai szakirodalomban elfogadott használatát. Fontosnak tartom hangsúlyozni azt, hogy a zöldút kifejezés nem alkalmas az ökológiai- és a zöldfolyosó kifejezések szinonimájaként 
való használatára, mert az ökológiai- és zöldfolyosók jelentős részében éppen az állati élőhely háborítatlanságát kell biztosítani, míg a zöldutak elsődleges szerepe az emberi kikapcsolódás számára alkalmas terek biztosítása. Természetesen vannak olyan ökológiai - és zöldfolyosók, amelyek (vagy egyes szakaszaik) zöldútként is használhatók, de ezt az adott területre vonatkozó tájvizsgálat alapján lehet eldönteni. A területhasználatot tekintve az ökológiai - és zöldfolyosók potenciális zöldutaknak tekinthetők: az élőhelyként is értékes zöldsávon belül ott kell megkeresni a zöldsétány helyét, ahol annak rekreációs létjogosultsága van (térségi útkapcsolat, kilátás stb.) és a legkevésbé zavarja az értékesebb élővilágot.

Európában az Európai Tanács határozatot hozott az Európai Ökológiai Hálózat (EECONET) létrehozásáról, amelynek célja az ökológiai rendszerek védelme és megörzése, a területek közötti biológiai kapcsolatok biztosítása, és így a biológiai sokféleség megőrzése. Magyarországon az Országos Területrendezési Tervről szóló törvény értelmében az ökológiai folyosók - a Nemzeti Ökológiai Hálózat részeként - a kiemelt térségi és megyei területrendezési tervekben önálló övezetként szerepelnek.

Az európai - elsősorban a közép-európai - zöldutak kialakítása a klasszikus amerikai példától eltérően alakul. A nagyrészt civil szervezetek által kijelölt zöldutak sok esetben nem újonnan létrehozott többfunkciós sávok, hanem jellemzően meglévő, nemmotoros használatra alkalmas gyalogos és/vagy kerékpáros útvonalak összekapcsolásával jönnek létre. E zöldutak különös értéke, hogy a tájszerkezeti szempontból különleges, történelmi kialakulású, racionális vonalvezetésű kereskedelmi útvonalaknak, régi szekérutaknak adnak a mai kor igényeinek megfelelő új szerepet.

A zöldút és a vele rokon fogalmak eredeti jelentéstartalmát a következő táblázatban foglalom össze (1. táblázat). 
1. táblázat: A zöldút és a vele rokon fogalmak jelentéstartalmai (saját szerkesztés, KAPOVITS, 2012)

\begin{tabular}{|c|c|c|c|c|c|}
\hline & $\begin{array}{l}\text { Parksétány } \\
\text { (Parkway) }\end{array}$ & $\begin{array}{l}\text { Zöldgyürü } \\
\text { (Greenbelt) }\end{array}$ & $\begin{array}{l}\text { Zöldút } \\
\text { (Greenway) }\end{array}$ & $\begin{array}{l}\text { Ökológiai folyosó } \\
\text { (Ecological corridor) }\end{array}$ & $\begin{array}{l}\text { Zöldfolyosó } \\
\text { (Green corridor) }\end{array}$ \\
\hline Fogalomalkotás ideje & 1866 & 1933 & 1987 & \multicolumn{2}{|c|}{1995} \\
\hline helye & New York & London & Washington & \multicolumn{2}{|c|}{ Brüsszel } \\
\hline A fogalom alkotója & $\begin{array}{l}\text { F.rederick Law } \\
\text { Olmsted }\end{array}$ & Raymond Unwin & $\begin{array}{l}\text { Elnöki Bizottság } \\
\text { Amerika } \\
\text { Szabadtereiért }\end{array}$ & \multicolumn{2}{|c|}{ Európai Unió és Európa Tanács } \\
\hline Eredeti jelentés & \begin{tabular}{|l|} 
fasorokkal \\
tagolt, \\
elválasztott \\
rendszerú városi \\
séta- és kocsiút
\end{tabular} & \begin{tabular}{|l|} 
beépítési \\
lehetőségeket \\
korlátozó \\
szabályozási övezet \\
nagyvárosok \\
környezetében
\end{tabular} & $\begin{array}{l}\text { gyaloglás és } \\
\text { kerékpározás } \\
\text { céljából kialakított } \\
\text { zöldsáv, amely } \\
\text { kapcsolatot teremt a } \\
\text { városi és a vidéki táj } \\
\text { között }\end{array}$ & $\begin{array}{l}\text { az ökológiai } \\
\text { hálózatok része, } \\
\text { különböző } \\
\text { élöhelyeket } \\
\text { összekötö lineáris } \\
\text { tér., elsődleges } \\
\text { alkotói a természetes } \\
\text { rendszer } \\
\text { maradványai }\end{array}$ & \begin{tabular}{|l|} 
az ökológiai \\
folyosók ember által \\
létrehozott típusa, \\
az ökológiai \\
barrierek által meg- \\
szakított élőhely- \\
kapcsolatok \\
helyreállítói
\end{tabular} \\
\hline
\end{tabular}

\subsection{A zöldút-tervezés lehetséges helye a területrendezési tervezés rendszerében}

\subsubsection{Kapcsolódás a területrendezési tervezés részeihez}

A zöldút-tervezés területi és települési tervezésbe illesztésének vizsgálatában alapvető kérdés, hogy a zöldút-hálózatoknak a területi és/vagy a települési tervezés mely szintjén és a tervezés mely részében (tervlapján) lehet helye. A kérdés megválaszolásához a területi és a települési tervezés munkarészeinek számbavételével, az azok kidolgozásához előírt tervezési léptékre való tekintettel elemzem a zöldút-tervezési célok megvalósításának és a zöldút-hálózat elemei szerepeltetésének lehetőségét. Az áttekintés vázát Gerzánics Annamária "Területrendezéshez kapcsolódó tájrendezés" címü könyvfejezete (GERZÁNICS, 2013) és az annak alapjául szolgáló jogszabályi háttér jelenti.

\section{Előkészitö fázis}

a) Vizsgálatok

E munkarész feladata többek között a vizsgálati adatok gyüjtése és értékelése, melynek egyik része a kerékpáros közlekedés, megközelíthetőségi viszonyok, kapcsolati hiányok vizsgálata és értékelése. Ehhez kapcsolódó munkarészként javasolom vizsgálni a nagy folyók és tavak (Duna, Tisza, Dráva, Balaton, Velencei-tó, Fertő tó, Tisza-tó) mentén alakuló kerékpáros útvonalak mellett - Magyarország Vízgyüjtő Gazdálkodási Tervében meghatározott 42 tervezési alegység figyelembe vételével - a vízgyüjtőként jelentős kisebb folyók, patakok (Rába, Marcal, Zala, Ipoly, Garam, Zagyva, Sajó, Bodrog, Maros, Körösök, Hernád, Békás-patak, Kígyós-patak stb.) környezetét 
kerékpáros célú hasznosítás, illetve hasznosítási lehetőség szempontjából. A vízgyüjtőként jelentős folyókhoz kapcsolódó kerékpáros - és esetenként egyéb rekreációs használatú - úthálózat az országos és megyei jelentőségű zöldút-hálózat klasszikus minta szerinti gerincét jelentené.

A vízfolyások mellett e munkarészhez kapcsolódóan javasolom vizsgálni a vasútvonalak környezetének országos és térségi zöldút-hálózatokhoz való bekapcsolási lehetőségét. A vizsgálatot és értékelést a az országos és a térségi vasúti infrastruktúra hierarchiájának figyelembevételével javaslom végezni, különös tekintettel a pályakorszerüsítések vagy egyéb okok miatt felhagyott vasútvonalak kerékpáros útvonalként megvalósult hasznosításának illetve hasznosítási lehetőségének vizsgálatára.

Szintén e munkarészhez javasolom felvenni a klasszikus zöldút modell harmadik típusának, a történelmi útvonalaknak térképi azonosítását és azok kerékpáros vagy egyéb nem motoros kirándulás céljából való hasznosítási lehetőségének vizsgálatát, különös tekintettel a tájrégészet ókori és középkori kereskedelmi és zarándokútvonalaira irányuló kutatásokra.

E három alapvető, országos és térségi zöldútlehetőség mellett ebben a részben szerepeltethetők és elemezhetők egyéb, sajátos táji adottságokra építhető, valamint civil szervezetek által kezdeményezett országos és térségi útvonaljavaslatok. (P1. Európai Zöldöv/Vasfüggöny kerékpáros és túraútvonal, Közép-Európai Borostyánkő Zöldút magyarországi szakasza stb.)

\section{b) Program}

A program munkarész a térségi szerkezeti terv első változata, amely tartalmazza a térségi területfelhasználás rendjét, a településrendszert, a müszaki infrastruktúra-hálózatok és egyedi építmények térbeli rendjét. E munkarész léptéke 1:50 000, a területfelhasználási kategóriákra vonatkozó legkisebb ábrázolható területegység az országos terv esetén 1000 ha. A kiemelt térségi és megyei tervek esetében ez a területnagyság jellemzően 50 ha, egyes esetekben 10 ha vagy 5 ha. A zöldút-hálózat új, önálló területfelhasználási kategóriaként nem jön szóba.

c) Területi hatásvizsgálat megkezdése

Ehhez a munkarészhez kapcsolódhat a zöldút terv hatására várhatóan bekövetkező környezeti, társadalmi és gazdasági jellemzők változásának elemzése a feltárt konfliktusok értékelésével

d) Környezeti vizsgálat és értékelés

Ebben a munkarészben megjelenhet a zöldút terv környezetvédelem és a fenntarthatóság szempontjából történő átfogó vizsgálata, különös tekintettel arra, hogy a zöldutak fejlesztése fokozatosan valósítható meg, nem igényel feltétlenül nagy anyagi befektetést (pl. aszfaltburkolatot), javasol viszont jelentős mértékü fásítást, amely a mezőgazdasági területek tájfásításához is kapcsolódihat; az erózió és defláció elleni védelmet is szolgálja 


\section{Javaslattevő fázis}

a) Térségi szerkezeti terv

\section{Területfelhasználási kategóriák}

A zöldút-hálózat elemei az érvényes területfelhasználási kategóriákkal - erdőgazdálkodási terület lefedhetők, ezért a zöldút új kategóriaként nem jeleníthető meg.

A települési rendszer elemei és a müszaki infrastruktúra hálózat

A települési rendszer elemeinek ábrázolása a települések nagyságrendjének bemutatást szolgálja, azon belül nem indokolt a zöldút-hálózat megjelenítése. A müszaki infrastruktúra-hálózat egyes elemeihez kapcsolódhatnak zöldutak (pl. folyó menti kerékpáros útvonalak zöldúttá fejleszthetők), létesíthetők a müszaki infrastruktúrától független zöldutak is, valamint megjelenhetnek az övezeti lapok között szereplő ökológiai hálózat egyes részein is. Mindezt figyelembe véve a zöldúthálózatok megjelenítése az övezeti lapok között célszerü.

\section{b) Térségi övezeti terv}

A zöldutak területrendezési tervezésben lehetséges megjelenítésére az övezetképzés célszerü tervezési eszköz lehet. Ezt a következő fejezetben részletesen kifejtem.

c) Területrendezési Szabályzat

A Területrendezési Szabályzatban jelenhetnek meg a zöldutak kialakítását ösztönző övezetre vonatkozó övezeti elöírások. Ennek megalapozására vonatkozó javaslataimat szintén kifejtem a következő fejezetben.

d) Megalapozó munkarészek

A zöldút terv térségi jelentősége miatt a területrendezési tervezés szakági megalapozó munkarészeként megjelenhet.

A szakági megalapozó munkarész tervezési területe lehet

— a település teljes belterülete vagy annak egy része,

- a település külterülete,

— a település teljes közigazgatási területe,

— 2-3 vagy több szomszédos település,

— kistáj vagy kistérség,

- megye,

- régió,

- Magyarország teljes területe,

— határokon átnyúló területek

a társadalmi igényektől és a táji adottságoktól függően. 


\section{2. táblázat: A zöldút-tervezési munkarészek beépitési lehetösége a területrendezési tervek elökészitő} munkarészébe (saját szerkesztés)

\begin{tabular}{|c|c|c|}
\hline \multirow[t]{2}{*}{ Területrendezési munkarész } & \multicolumn{2}{|c|}{ zöldút-tervezési munkarész } \\
\hline & Országos szint & Megyei /kiemelt térségi szint \\
\hline \multirow[t]{4}{*}{ Vizsgálatok } & $\begin{array}{l}\text { országos részvízgyüjtőként jelentős nagy } \\
\text { folyók és tavak parti környezetei gyalogos, } \\
\text { kerékpáros, lovas hasznosításának, illetve } \\
\text { hasznosítási lehetőségeinek vizsgálata }\end{array}$ & $\begin{array}{l}\text { térségi vízgyüjtőként jelentős kisebb folyók } \\
\text { és tavak parti környezetei gyalogos, } \\
\text { kerékpáros, lovas hasznosításának, illetve } \\
\text { hasznosítási lehetőségeinek vizsgálata }\end{array}$ \\
\hline & $\begin{array}{l}\text { országos jelentőségü vasútvonalak } \\
\text { környezetei gyalogos, kerékpáros, lovas } \\
\text { hasznosításának, illetve hasznosítási } \\
\text { lehetőségeinek vizsgálata }\end{array}$ & $\begin{array}{l}\text { térségi jelentőségű vasútvonalak } \\
\text { környezetei gyalogos, kerékpáros, lovas } \\
\text { hasznosításának, illetve hasznosítási } \\
\text { lehetőségeinek vizsgálata }\end{array}$ \\
\hline & $\begin{array}{l}\text { országos jelentőségű történelmi útvonalak } \\
\text { térképi azonosítása, és azok gyalogos, } \\
\text { kerékpáros, lovas hasznosításának, illetve } \\
\text { hasznosítási lehetőségének vizsgálata }\end{array}$ & $\begin{array}{l}\text { térségi jelentőségű történelmi útvonalak és } \\
\text { településközi földutak térképi azonosítása, } \\
\text { és azok gyalogos, kerékpáros, lovas } \\
\text { hasznosításának, illetve hasznosítási } \\
\text { lehetőségének vizsgálata }\end{array}$ \\
\hline & $\begin{array}{l}\text { egyéb országos jelentőségű sajátos táji } \\
\text { adottságokra építhető, valamint civil } \\
\text { szervezetek által kezdeményezett } \\
\text { útvonaljavaslatok térképi azonosítása és } \\
\text { elemzése }\end{array}$ & $\begin{array}{l}\text { egyéb térségi jelentőségű sajátos táji } \\
\text { adottságokra építhető, valamint civil } \\
\text { szervezetek által kezdeményezett } \\
\text { útvonaljavaslatok térképi azonosítása és } \\
\text { elemzése }\end{array}$ \\
\hline Program & $\begin{array}{l}\text { országos szintü zöldút-hálózat első } \\
\text { változatának megjelenése }\end{array}$ & $\begin{array}{l}\text { térségi szintủ zöldút-hálózat első } \\
\text { változatának megjelenése }\end{array}$ \\
\hline $\begin{array}{l}\text { Területi hatásvizsgálat } \\
\text { megkezdése }\end{array}$ & \multicolumn{2}{|c|}{$\begin{array}{l}\text { a zöldút terv hatására várhatóan bekövetkező környezeti, társadalmi és gazdasági } \\
\text { jellemzők változásának elemzése a feltárt konfliktusok értékelésével }\end{array}$} \\
\hline Környezeti vizsgálat & \multicolumn{2}{|c|}{$\begin{array}{l}\text { a zöldút terv környezetvédelem és a fenntarthatóság szempontjából történő átfogó } \\
\text { vizsgálata }\end{array}$} \\
\hline
\end{tabular}

3. táblázat: A zöldút-tervezési munkarészek beépitési lehetösége a területrendezési tervek javaslattevő munkarészeibe (saját szerkesztés)

\begin{tabular}{|c|c|c|}
\hline \multirow[t]{2}{*}{ Területrendezési munkarész } & \multicolumn{2}{|c|}{ zöldút-tervezési munkarész } \\
\hline & Országos szint & Megyei /kiemelt térségi szint \\
\hline \multicolumn{3}{|l|}{$\begin{array}{c}\text { Elfogadásra kerïlö munkarészek } \\
\text { Térségi szerkezeti terv }\end{array}$} \\
\hline Területfelhasználási kategóriák & \multicolumn{2}{|c|}{$\begin{array}{l}\text { a zöldút-hálózat elemei az érvényes területfelhasználási kategóriákkal } \\
\text { lefedhetők, ezért a zöldút új kategóriaként nem jeleníthető meg }\end{array}$} \\
\hline A településrendszer elemei & - & - \\
\hline Müszaki infrastruktúra hálózat & \multicolumn{2}{|l|}{-} \\
\hline \multicolumn{3}{|l|}{ Térségi övezeti terv } \\
\hline Térségi övezetek & \multicolumn{2}{|c|}{ zöldút létesítésre javasolt térségi övezet lehatárolása } \\
\hline Területrendezési szabályzat & \multicolumn{2}{|c|}{$\begin{array}{l}\text { a zöldút létesítésre javasolt térségi övezet területhasználati szabályainak } \\
\text { megfogalmazása }\end{array}$} \\
\hline \multicolumn{3}{|l|}{ Megalapozó munkarészek } \\
\hline Szakági tervjavaslatok & \multicolumn{2}{|l|}{ zöldút terv } \\
\hline Területi hatásvizsgálat & \multicolumn{2}{|l|}{ lehetőség szerint } \\
\hline
\end{tabular}




\subsection{2. "Zöldút kialakítására alkalmas övezet" képzésének megalapozása}

A térségi övezetképzés lehetösége

"A területi tervezésben az övezeti szabályozás lehetőséget biztosít arra, hogy a különböző szempontból védelemre érdemes vagy területhasználati szempontból eltérően kezelendő területek lehatárolásra kerüljenek, és az így lehatárolt területekre vonatkozóan külön elöírások is meghatározhatók legyenek." (GERZÁNICS, 2013)

\section{"Zöldút kialakitására alkalmas övezet" megállapításának lehetösége}

A zöldutak alapvető elemeit (nyomvonal, keresztmetszet, kapcsolódó zöldfelületek, egyéb tárgyi elemek) bemutató 5.1. fejezet alapján a zöldutak területhasználati szempontból önállóan kezelendő területeknek tekinthetők, ezért optimális kialakításukat, fejlesztésüket és fenntartásukat önálló térségi övezet lehatárolása biztosíthatja. A területrendezési tervezéshez kapcsolódó térségi övezetképzés a zöldút-tervezés számára jó tervezési eszköz lehet, mert a zöldutak tervezése a települési szint feletti, térségi tervezést igényel, valamint azért, mert a zöldút-tervezés a területrendezési tervek szerkezeti tervében szereplő területfelhasználási kategóriák megváltoztatása nélkül, az azokon megvalósuló új - rekreációs célú - használatok tervezésére irányul.

\section{"Zöldút kialakitására alkalmas övezet" képzésének célja}

Az új térségi övezet képzésének célja elsősorban olyan, tájszerkezeti szempontból különösen értékes tájelemek (vízparti területek, felhagyott vasútvonalak, történelmi útvonalak, mezőgazdasági útként fennmaradt egykori településközi szekérutak stb.) és környezetük megörzése és védelme, amelyek többféle kirándulás számára egyaránt vonzó lehetőséget jelentenek. Az övezetképzés célja másodsorban a zöldút kialakítására alkalmas vonalas tájelemek rekreációs lehetőségeinek feltárása és optimális zöldfelületi fejlesztése, amely térségi jelentőségü, hierarchikus rendszert alkotó, rekreációs és ökológiai szempontból egyaránt jelentős szerepü zöldút-hálózatok létrejöttét eredményezheti.

A zöldút-tervezéshez kapcsolódó térségi övezetképzés lehetséges szerepei

A települések külterületéhez tartozó területek - különösen a szántóföldi és kertgazdálkodási használatú mezőgazdasági térségekben, valamint a vízgazdálkodási térségekben - növekvő rekreációs és turisztikai használata nem magától értetődő, sőt egyes területeken a legfőbb gazdálkodási munkaidőben tájhasználati konfliktust okoz. A zöldutak használhatósága, fenntartási és fejlesztési kereteinek meghatározásához a területrendezési tervezéshez kapcsolódó térségi övezetképzés megfelelő eszközként szolgálhat. Az övezetképzés lehetőséget nyújthat

— a szomszédos településeket összekötő, rekreációs céllal kiemelten fejlesztendő zöldút-hálózat 
területrendezési tervekben történő térbeli lehetőségeinek meghatározására;

- a térségi övezet területi lehatárolásának és tartalmi elemeinek finomítására a településrendezési tervezés, illetve szükség szerint az objektum szintű tervezés során lehetőség van;

— a településrendezési tervek rendszeres felülvizsgálatához kapcsolódóan, a változó igényektől függően szükség szerint rugalmasan bővíthető a zöldút számára lehatárolt terület (pl. útszélesítés, fásítás vagy kapcsoló rekreáció szerepü zöldfelületi bővítés céljából);

— a zöldút-hálózat optimális használatának, fejlesztésének és fenntarthatóságának ösztönzése érdekében a használói, valamint a tulajdonosi, kezelői és fenntartói jogok és kötelezettségek

- a tervezéshez kapcsolódóan meghatározhatók;

— a várható hazai és uniós zöldfelületi fejlesztésre irányuló pályázati források optimális felhasználásának előkészítésére.

Az övezetképzés lehetséges helye a területrendezési tervezés hierarchiájában

Tekintettel a területrendezési tervek léptékének törvényi elöírására, a "zöldút kialakítására javasolt térségi övezet" kijelölése a területrendezési tervezés különféle szintjein, az egyes zöldutak hierarchikus szerepének megfelelően lehetséges. Az országos jelentőségű (elsősorban a fö- és mellékfolyók, nagy tavak, legfőbb történelmi útvonalak mentén stb. kialakítható) zöldutak megjelenhetnek az Országos Területrendezési Terv övezeti tervében. Az országos jelentőségü zöldutakhoz kapcsolható megyei vagy kiemelt térségi jelentőségü (egyes mellékfolyók, patakok, mezőgazdasági útként fennmaradt egykori településközi utak stb.) mentén kialakítható zöldutak a megyei és a kiemelt térségi tervek övezeti terveiben jelenhetnek meg. Amennyiben a megyei és a kiemelt térségi tervekben a "zöldút kialakítására javasolt térségi övezetek" lehatárolása és az övezeti elöírások elfogadásra kerülnek, a térségi övezeti előírások a településrendezési tervezés során érvényesíthetők.

\section{A javasolt övezet gyakorlati bevezetésének szempontjai}

Az övezet területrendezési tervekben történő bevezetésénél fontos szempont, hogy az övezet térségi szintü kijelölése települési szinten birtok- és telekrendezési feladatokat is jelenthet (például új, közhasználatú utak létesítése vagy meglévő utak szélesítése mezőgazdasági területeken, patakmeder rendezés stb.). A "zöldút kialakítására javasolt térségi övezet" megjelenése a területrendezési tervekben új - anyagi háttér biztosítását is igénylő -, térségi és települési szintű szerepvállalást, kötelezettségek vállalását is igényeli (tervezési, megvalósítási, fenntartási feladatok). Az új övezet gyakorlati bevezetésénél - konkrét tervezési területeken - ezen szempontoknak az igények és a lehetőségek felmérésére alapozott átfogó elemzése szükséges. 


\section{A javasolt övezet gyakorlati alkalmazásának lehetősége}

Az új övezet bevezetése elsőként a kiemelt térségi tervekben (a Budapesti Agglomeráció Területrendezési Tervében és Balaton Kiemelt Üdülökörzet Területrendezési Tervében) jelenik meg, különös tekintettel arra, hogy a kiemelt térségi tervek készítése során a 218/2009. (X.6.) Korm. rendelet alapján lehetőség van az Országos Területrendezési Tervben nem meghatározott új térségi övezetek képzésére.

A "zöldút kialakitására alkalmas térségi övezet" területére javasolt elöirások

$\mathrm{Az}$ általam javasolt övezet területén érvényesítendő elöírások a rekreációs használat számára optimális műszaki-zöldfelületi megoldások és ökológiai értékek megörzésének összehangolását szolgálják.

- Az övezet területén biztosítani kell többféle rekreációs használat számára alkalmas utak kialakítását és azok - kerítéssel történő lezárás vagy motoros közlekedés által meg nem szakított - folyamatosságát.

— Az övezet területét a települési zöldfelületekhez kapcsolódóan kell tervezni, fejleszteni és fenntartani.

— Az övezetbe tartozó terület használatának (rekreációs használat, mezőgazdasági használat) szabályait helyi rendeletben kell megállapítani.

A javasolt térségi övezet kialakitásához szükséges adatok

A javasolt térségi övezet lehatárolása tervezői lehatárolással történhet.

A területi lehatárolások és az előírások megfogalmazása a következő adatok alapján történhet:

- térségi szerkezeti terv,

— térségi ökológiai hálózat övezeti tervei,

- településrendezési tervek,

- történeti térképek,

— tájrégészeti kutatások eredményei,

- a helyi emlékezet és hagyomány,

— helyszíni bejárások tapasztalatai.

\subsection{A térségi szintű zöldút-tervezés metodikai alapjai}

A zöldút tervek alapvető tartalmi követelménye olyan rekreációs és ökológiai szereppel is rendelkező hálózat létesítése, amely az olmstedi tájépítészeti gondolaton alapuló zöldút modell 
jellemzőivel rendelkezik. A zöldút-tervezés - melynek fő célja településeket összekötő rekreációs szerepű zöldfelületi hálózat létrehozása - jellemző tervezési léptéke a megyei, térségi, kistérségi szint. A megyei, térségi, kistérségi szinten átgondolt zöldút terv illeszkedhet az országos szintü területrendezési tervezés, illetve a helyi szintü településrendezési tervezés folyamatába. A zöldúttervezés területrendezési tervezésbe integrálásával biztosítható, hogy a zöldutak összetett területi vonatkozású szempontjai, hatásai, tervezési feladatai és lehetséges megoldásai alapos megfontolás tárgyát képezzék, és rendszeres felülvizsgálatok során a zöldutak szükség szerint fejleszthetők legyenek. A zöldút-tervezés a táji adottságoktól és a társadalmi igényektől függően a területrendezési tervek önálló, alátámasztó munkarészeként is megjelenhet. A zöldút-tervezést ebben az esetben célszerü általánosan alkalmazható zöldút-tervezési metodika kidolgozásával ösztönözni.

A következőkben a zöldút-tervezési metodika munkarészeinek tartalmi elemeire teszek javaslatokat.

\subsubsection{A zöldút-tervezési feladatok meghatározása a zöldutak tipizálásával}

Adott tervezési területre vonatkozó zöldút-tervezési feladatokat a zöldút kialakítására alkalmas területek térbeli elhelyezkedése és a zöldutak térségi szerepe együttesen határozzák meg. Elhelyezkedés és térségi szerep szerint zöldút típusok meghatározását javasolom. Tipizálási javaslatomban meghatározom a zöldút-tervezés általános, közös feladatait, valamint az egyes zöldút típusokra vonatkozó sajátos tervezési feladatokat. A javasolt zöldút típusokhoz meghatározom a lehetséges nyomvonalakat és a szükséges tervezési feladatokat. (4. táblázat)

\section{Elhelyezkedés szerinti tipizálás}

Elhelyezkedés szerint a klasszikus zöldutak példáján három zöldút típust határozok meg:

- vízparti zöldutak,

— felhagyott vasútvonalak menti zöldutak,

— történelmi útvonalak menti zöldutak.

A kutatási mintaterületen megvalósítható zöldút-hálózat példája, és annak lehetséges kiterjesztése alapján meghatározok egy új, a hazai táji adottságokon alapozó zöldút típust:

— hagyományos településközi utak menti zöldutak.

Tekintettel arra, hogy vannak olyan útvonalak, amelyek az előző típusokba nem sorolhatók be, de a javasolt zöldút definíció szerint a zöldút jellemzőivel rendelkezhetnek, meghatározok még egy zöldút típust:

— egyéb, sajátos zöldutak 
A települések beépített területein átvezető zöldút szakaszok tervezése eltér a nem beépített szakaszok tervezésétől, sok esetben a gyalogos és kerékpáros útvonalak számára más útvonal a megfelelő. Ugyanakkor megfelelő adottságok esetén (pl. vízparti területek) közös útszakaszok is lehetnek. Ezért még egy típust meghatározok:

— településen belüli zöldút típus

\section{Vizparti zöldutak}

A vízparti zöldút típus lehetséges területei

— a fö folyók és part menti területeik,

- a mellékfolyók és part menti területeik,

- a patakok és a patak menti területek,

— az élővíz-csatornák part menti területei,

- a tóparti területek lehetnek.

A zöldút-tervezés általános feladatai mellett ebben az esetben sajátos feladatot jelentenek a következők:

— folyóvizek hidrológiai és ökológiai állapotának feltárása,

— patakmeder-rendezés lehetőségének vizsgálata,

— part menti növényzet ökológiai állapotának felmérése,

— vízi közlekedés lehetőségének vizsgálata,

— vízparti növénytársulások megőrzése, illetve telepítése.

\section{Felhagyott vasútvonalak menti zöldutak}

A felhagyott vasútvonalak menti zöldutak lehetséges területei

- a vasútvonal korszerüsítés során felhagyottá vált nyomvonalak és

— a közlekedési és gazdasági elemzések alapján megszüntetésre javasolt vasútvonalak

A zöldút-tervezés általános feladatai mellett ebben az esetben sajátos feladatot jelentenek a következők:

— a vasútvonal üzemeltetésére vonatkozó közlekedési és gazdasági elemzések értékelése,

— a vasútvonal történetének áttekintése,

— a vasúthoz kapcsolódó tájértékek felmérése. 


\section{Történelmi útvonalak menti zöldutak}

- a római kori kereskedelmi útvonalak,

- a középkori kereskedelmi- és zarándokutak,

— az egyéb történelmi jelentőségű útvonalak mentén létesíthetők.

A zöldút-tervezés általános feladatai mellett ebben az esetben sajátos tervezési feladatot jelentenek

- a történeti térképek elemzése,

— a történelmi utak nyomvonalainak kialakulást meghatározó tényezők feltárása,

- a vonatkozó tájrégészeti kutatások áttekintése.

\section{Hagyományos településközi utak menti zöldutak}

A kutatási mintaterületen megvalósítható zöldút-hálózat példája, és annak lehetséges kiterjesztése alapján meghatározok egy új, a hazai táji adottságokon alapozó zöldút típust, amelynek elnevezésére a 'hagyományos településközi út menti zöldút típus' kifejezést javasolom.

Hagyományos településközi út menti zöldutak kialakíthatók mezőgazdasági útként fennmaradt, hagyományosan kialakult településközi szekérutak nyomvonalai mentén.

Az általános zöldút-tervezési feladatok mellett ebben az esetben sajátos feladatot jelentenek

- történeti térképek elemzése,

- hagyományos településközi utak feltárása a helyi emlékezet és hagyomány alapján, és térképi azonosításuk,

— a hagyományos településközi utak és környezetük mezőgazdasági tájhasználatának elemzése.

Egyéb, sajátos zöldutak

Vannak olyan zöldutak, amelyek az előző típusokba nem sorolhatók be, de a javasolt zöldút definíció szerint a zöldút jellemzőivel rendelkezhetnek. Ezek olyan önálló típust alkothatnak, amelyek elnevezésére az 'egyéb, sajátos zöldút' kifejezést javasolom.

Egyéb, sajátos zöldút típushoz tartozhat például a nyugati országhatár mentén az egykori 'vasfüggöny' területén kialakult zöldsáv, amelynek rekreációs szerepü fejlesztése folyamatban van. Egyéb, sajátos típushoz sosrolom azokat a zöldút szakaszokat, amelyek az egyéb zöldút típusok összekötését szolgálják.

E zöldutak tervezése során az általános zöldút-tervezési feladatok mellett sajátos feladatot jelentenek

— a kialakulásukat meghatározó tényezők feltárása és

— a sajátos karakterük meghatározása. 


\section{4. táblázat: Összefoglalás a zöldutak elhelyezkedés szerinti típusairól és azok feladatairól}

\begin{tabular}{|c|c|c|c|}
\hline \multirow[t]{2}{*}{ zöldút típus } & \multirow[t]{2}{*}{ lehetséges nyomvonalak } & \multicolumn{2}{|c|}{ tervezési feladatok } \\
\hline & & \multirow{5}{*}{\begin{tabular}{|l|}
\multicolumn{1}{c|}{ általános } \\
- tervezési terület lehatárolása \\
- tájtörténeti vizsgálat \\
- területhasználat elemzése \\
- ökológiai állapot feltárása \\
- kapcsolódó tájértékek \\
vizsgálata \\
- rekreációs igények vizsgálata \\
- meglévö és tervezett \\
gyalogos, kerékpáros és lovas \\
útvonalak vizsgálata \\
- tulajdonviszonyok vizsgálata \\
- jóváhagyott és folyamatban \\
lévő területrendezési és \\
településrendezési tervek \\
vizsgálata \\
- jóváhagyott és folyamatban \\
lévő közlekedésfejlesztési \\
tervek vizsgálata \\
- meglévő és felmerülö \\
tájhasználati konfliktusok \\
feltárása \\
- jóváhagyott és folyamatban \\
lévő zöldfelületi tervek \\
vizsgálata \\
- területi vonatkozású \\
társadalmi kezdeményezések \\
vizsgálata \\
- optimális zöldút nyomvonalak \\
kiválasztása \\
- zöldút szakaszok optimális \\
térbeli kialakításának \\
meghatározása \\
- zöldutak zöldfelületi tervezése \\
\end{tabular}} & sajátos \\
\hline vízparti zöldutak & $\begin{array}{l}\text { - fö folyók partmenti } \\
\text { területei } \\
\text { - mellékfolyók partmenti } \\
\text { területei } \\
\text { - patak menti területek } \\
\text { - élövíz-csatornák partmenti } \\
\text { területei } \\
\text { - tóparti területek }\end{array}$ & & $\begin{array}{l}\text { - folyóvizek hidrológiai és } \\
\text { ökológiai állapotának } \\
\text { feltárása } \\
\text { - patakmeder- rendezés } \\
\text { lehetőségének vizsgálata } \\
\text { - partmenti növényzet } \\
\text { ökológiai állapotának } \\
\text { felmérése } \\
\text { - vízi közlekedés } \\
\text { lehetőségének vizsgálata } \\
\text { - vízparti } \\
\text { növénytársulások } \\
\text { megőrzése, illetve } \\
\text { telepítése }\end{array}$ \\
\hline $\begin{array}{l}\text { felhagyott vasútvonalak } \\
\text { menti zöldutak }\end{array}$ & $\begin{array}{l}\text { - vasútvonal korszerüsítés } \\
\text { során felhagyottá vált } \\
\text { nyomvonalak } \\
\text { - közlekedési és } \\
\text { közgazdasági elemzések } \\
\text { alapján megszüntetésre } \\
\text { javasolt vasútvonalak }\end{array}$ & & $\begin{array}{l}\text { - a vasútvonal } \\
\text { üzemeltetésére vonatkozó } \\
\text { közlekedési és } \\
\text { közgazdasági elemzések } \\
\text { értékelése } \\
\text { - vasútvonal történetének } \\
\text { áttekintése } \\
\text { - vasúthoz kapcsolódó } \\
\text { tájértékek felmérése }\end{array}$ \\
\hline $\begin{array}{l}\text { történelmi útvonalak } \\
\text { menti zöldutak }\end{array}$ & $\begin{array}{l}\text { - római kori kereskedelmi } \\
\text { útvonalak } \\
\text { - középkori kereskedelmi- } \\
\text { és zarándokutak } \\
\text { - egyéb történelmi } \\
\text { jelentőségü útvonalak }\end{array}$ & & $\begin{array}{l}\text { - történeti térképek } \\
\text { elemzése } \\
\text { - történelmi utak egykori } \\
\text { használatának kutatása } \\
\text { - vonatkozó tájrégészeti } \\
\text { kutatások áttekintése }\end{array}$ \\
\hline $\begin{array}{l}\text { hagyományos } \\
\text { településközi utak menti } \\
\text { zöldutak }\end{array}$ & $\begin{array}{l}\text { - mezőgazdasági útként } \\
\text { fennmaradt településközi } \\
\text { utak nyomvonalai }\end{array}$ & & $\begin{array}{l}\text { - történeti térképek } \\
\text { elemzése } \\
\text { - hagyományos helyi } \\
\text { közlekedési útvonalak, } \\
\text { zarándokutak feltárása a } \\
\text { helyi emlékezet és } \\
\text { hagyomány alapján, majd } \\
\text { térképi azonosításuk, } \\
\text { - a hagyományos } \\
\text { településközi szekérutak és } \\
\text { környezetük } \\
\text { mezőgazdasági } \\
\text { tájhasználatának elemzése. }\end{array}$ \\
\hline egyéb, sajátos zöldutak & $\begin{array}{l}\text { - egyéb sajátos, rekreációs } \\
\text { és ökológiai szereppel } \\
\text { egyaránt rendelkező vonalas } \\
\text { tájelemek }\end{array}$ & & $\begin{array}{l}\text { - a kialakulásukat } \\
\text { meghatározó tényezők } \\
\text { feltárása } \\
\text {-- sajátos karakterük } \\
\text { meghatározása }\end{array}$ \\
\hline
\end{tabular}


A Zsámbéki-medence területére javasolt térségi szintü zöldút-hálózat koncepció javaslatom példáján bemutatom a zöldút-hálózaton belül megjelenő zöldút típusokat. (22. ábra)
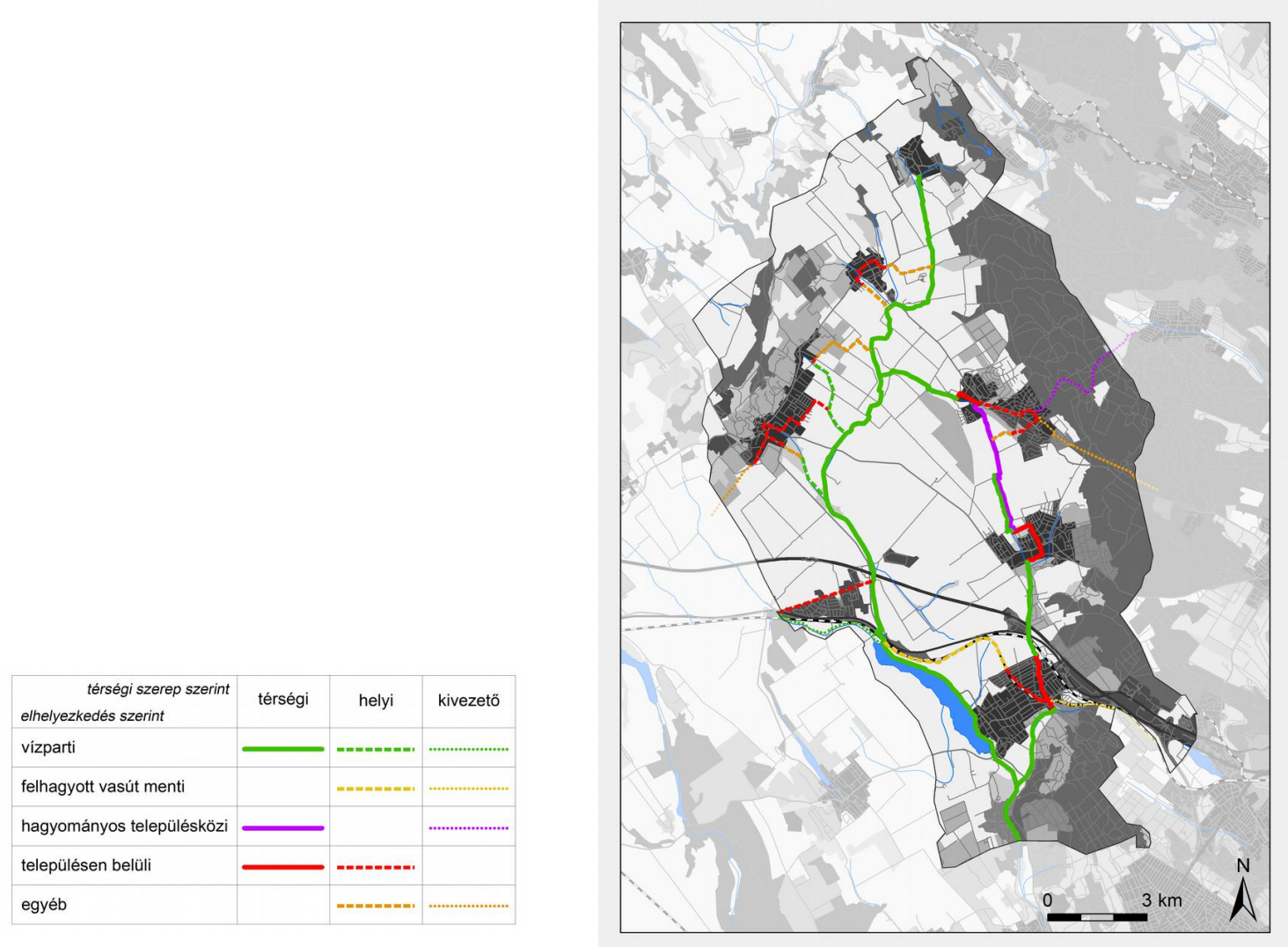

22. ábra: Zöldúttípusok a Zsámbéki-medence példáján

\subsubsection{A zöldút-hálózat koncepció}

\section{Nyomvonalválasztás}

A zöldút-hálózat koncepció kialakításának első lépése a nyomvonalak kiválasztása. Egy adott tervezési területen vizsgálni kell az elhelyezkedés szerinti zöldútt típusok létesítésének lehetőségét a tájtörténeti elemzések, a helyszíni bejárások tapasztalatai, az észlelt tájhasználati konfliktusok , az érvényes területrendezési és településtervezési tervek, a jövőképek, a helyi és a térségi szinten észlelhető rekreációs igények alapján.

\section{Keresztmetszeti kialakitás}

Zöldutak optimális kialakításán a táji adottságokhoz, valamint az adott rekreációs igényekhez és a várható forgalomhoz illeszkedő tájépítészeti kialakítást értem. Ez azt jelenti, hogy a zöldutak térbeli kialakítását tekintve a tervezési beavatkozást nem igénylő útvonal kijelöléstől a komplex tervezést 
igénylő, többféle kirándulási forma számára elválasztott rendszerü kialakításig többféle változat megjelenhet. Az optimális kialakítás módjának meghatározása biztosítható a zöldút-tervezés területrendezési tervezésbe történő integrálásával, amelyen belül a zöldút kialakítást ösztönző térségi övezetképzés szerepe fontos szerepet játszhat. Az övezetkijelölés biztosíthatja hosszabb távon a zöldút kialakításra alkalmas területek megőrzését. A területrendezési tervezés folyamatához kapcsolódó rendszeres felülvizsgálatok, illetve a településrendezési tervezés során az igények és a lehetőségek változásának megfelelően lehetőség nyílik a zöldutak optimális fejlesztésére.

$\mathrm{Az}$ optimális megoldás a kevés beavatkozást is jelentheti. Például meglévő útvonal változatlanul hagyása akkor, ha nincs szükség beavatkozásra. Vagy: zöldfelületi tervezés jelenthet fasor telepítést az árnyék biztosítása miatt vagy fasor elhagyását a feltáruló tájkép érvényesülése érdekében.

\section{Csomóponttervezés}

Az olmstedi zöldút modell alapján a zöldutak alapvető jellemzője az útvonalak biztonságos, zavartalan használata. A lehetséges zöldút nyomvonalak és a meglévő közlekedési infrastruktúra csomópontjai azonban sok esetben olyan adottságot jelentenek (vízfolyások feletti szűk alagutak, a föutak, autópályák, vasútvonalak külön szintü csomópontjainál), költséges müszaki megoldásssal vagy egyes szakaszokon az eredeti koncepció szerinti zöldút nyomvonal korrekcióját teszik szükségessé.

A Zsámbéki-medence példáján bemutatott 'zöldút kialakítására javasolt térségi övezet' lehatárolása a területrendezési tervezés folyamatában azt is szolgálná, hogy az övezet területén az optimális zöldút myomvonalak és a csomóponti megoldások a településrendezésii tervezés során tovább finomíthatók legyenek. Ez azt is jelenti, hogy az új zöldút-út csomópontok tervezésénél a zöldútra alkalmas vízparti, felhagyott vasútvonalak menti, hagyományos településközi út menti stb. területek - tájszerkezeti és tájökológiai értéküknek megfelelő jelentőséget kapjanak. 


\section{KUTATÁSI EREDMÉNYEK/TÉZISEK}

Kutatásom eredményeként megadom a válaszokat a kutatás kezdetén feltett kérdésekre, majd tézisek formájában összegzem a kutatómunkám során feltárt összefüggésekre alapozott új vagy újszerü, a hazai tájépítészeti kutatásokban és a tervezési gyakorlatban alkalmazható megállapításokat.

\subsection{A kutatási kérdésekre adott válaszok}

Hogyan lehetséges a Zsámbéki-medencében a Budavidék Zöldút Szövetség által gyaloglásra és kerékpározásra javasolt civil zöldút-hálózat szerepeltetése a tájépitészeti tervezésben annak érdekében, hogy a javasolt és egyre népszerübb útvonalak ne szünhessenek meg vagy ne szakadhassanak meg új beépitések miatt?

Válasz: A civil egyesület által javasolt zöldút-hálózat a meglévő, gyaloglásra és kerékpározásra alkalmas útvonalak helyszíni bejárás alapján történt kiválasztásával és összefüggő hálózattá alakításával jött létre. A civil zöldút-hálózat tájépítészeti tervezésben történő szerepeltetéséhez a civil javaslatok tájépítészeti elemzése szükséges. A tájépítészeti elemzés alapján a rekreációs használatra alkalmas zöldutak jogi értelemben lehetséges megőrzése, illetve fejlesztése a tájépítészeti javaslatok területrendezési és településtervezési tervezésbe történő integrálásával történhet. Dolgozatomban javaslatot adtam a zöldút fogalom tervezési szempontból egyértelmü meghatározására, valamint a magyarországi zöldút-tervezésre vonatkozó tervezési metodika megalapozására.

Hogyan határozhatók meg a zöldút-hálózat optimális nyomvonalai és optimális keresztmetszeti kialakitási módjai?

Válasz: A zöldút-hálózat optimális nyomvonalait és keresztmetszeti kialakítási lehetőségeit a zöldút-tervezésre vonatkozó tájépítészeti szakirodalom tanulmányozása és az ott megfogalmazott ajánlások magyarországi alkalmazhatóságának elemzésével határoztam meg. Optimális nyomvonalaknak a klasszikus zöldutak példái alapján a vízparti területeket, egyes felhagyott vasúti nyomvonalakat, egyes történelmi útvonalakat, valamint - a mintaterületen végzett kutatásaim kiterjesztése alapján - a mezőgazdasági útként fennmaradt hagyományos településközi utakat tekintem. A zöldutak optimális keresztmetszeti kialakítását az adott tervezési területen érzékelhető igények és a használók számának rendszeres mérésével és várható előrejelzésével javasolom meghatározni. Ennek értelmében a zöldutak térbeli megjelenése a meglévő, járható utak beavatkozás nélküli formájától a jelentős müszaki és zöldfelületi beavatkozást jelentő fejlesztésekig változatos lehet. 
Alkalmazható-e - és milyen eltérésekkel és sajátosságokkal - a zöldút modell Magyarországon?

Válasz: A tájépítészeti szakirodalom a zöldút-tervezés modelljének egyhangúan Frederick Law Olmsted Bostonban megvalósult 'Emerald Necklace' elnevezésű parkrendszerének tervezési koncepcióját és annak táji léptékü kiterjesztését tekinti. Kutatásom során a szakirodalom tanulmányozása és az 'Emerald Necklace' tanulmányúton történt helyszíni bejárása alapján kiemeltem az olmstedi modell meghatározó térbeli jellemzőit, majd az olmstedi modell táji léptékü kiterjesztésének meghatározó lépéseit az amerikai tájépítészeti tervezésben. Áttekintettem a zöldút modell európai megjelenését. Megállapítottam, hogy a zöldút gondolata a tájépítészeti tervezésben és civil mozgalmak keretében is megjelent. Megállapítottam, hogy a zöldutak tartalmi értelmezése és a megvalósítás módjai eltérők. A zöldút modell magyarországi alkalmazhatóságát a tájépítészeti tervezési koncepció meghatározó jellemzőit tekintve határoztam meg, ugyanakkor figyelembe vettem a zöldút mozgalmak területi vonatkozású eredményeit is.

Megállapítottam, hogy a zöldút modell alapvető jellemzői - az alapvetően vonalas tájszerkezeti elemként megjelenő rekreációs útvonalak zöldfelületi rendszerré fejlesztése, a természetes vagy természetközeli területekhez kötődő tájszerkezeti elemek (folyó-, patak- és tópartok, felhagyott vasútvonalak, történelmi útvonalak) kiválasztása, többféle rekreációs használati mód együttes térbeli biztosítása, a rekreációs és az ökológiai tervezési feladatok összekapcsolása - a zöldút modell hazai alkalmazhatóságának alapvető elemei. A zöldút modell hazai alkalmazásában eltérésként jelenik meg a felhagyott vasútvonalak zöldútként történő kialakítási lehetősége. A felhagyott vasútvonalakon a vasúti forgalom megszüntetésének eldöntéséhez alapos gazdasági elemzések is szükségesek. Zöldút kialakítására elsősorban a vasúthálózat korszerűsítése során felhagyottá vált szakaszok jönnek szóba. A mintaterületen végzett kutatásaim alapján megállapítottam, hogy a klasszikus zöldút lehetőségek mellett a hazai zöldút-hálózat meghatározó részei lehetnek a mezőgazdasági útként fennmaradt hagyományos településközi utak. A zöldút fogalom tartalmi értelmezésében eltérést jelent az, hogy az ökológiai folyosó európai uniós szóhasználatának megfelelően Magyarországon nem értelmezhető az önálló ökológiai funkcióval rendelkező zöldutak csoportja. A zöldutak minden esetben ökológiai és rekreációs funkcióval egyaránt jelentkező tájelemeket foglalnak magukba (ennek értelmében a zöldfolyosók rekreációs szerepű fejlesztése zöldút létesítését jelenti).

Hogyan alkotható meg a hazai területrendezési és településrendezési tervezésbe illeszthető zöldút definíció?

Válasz: Megállapítottam, hogy a területrendezési és településrendezési tervezésbe illeszthető zöldút definíció megfogalmazásában egyértelműen meg kell jelennie a olmstedi zöldút modell alapvető térbeli jellemzőinek, kifejezésre kell juttatni a zöldút-tervezés lehetséges tervezési szintjeit 
és egyértelművé kell tenni a zöldút sajátos jellemzőit, szerepét és újszerűségét a gyalogos, kerékpáros és lovas útvonalakhoz képest, valamint hangsúlyozni kell a rekreációs és az ökológiai, valamint a müszaki és az ökológiai tervezés együttes tervezésének szükségességét.

Hogyan határozható meg a zöldút-tervezés helye a hazai területrendezési és településrendezési tervezés rendszerében?

Válasz: A tájépítészeti szakirodalomban megjelent publikációk és gyakorlatban megvalósult példák alapján, valamint a mintaterületre készített zöldút-hálózat koncepciója alapján bemutattam a zöldút-tervezés térségi jelentőségét, a zöldút-hálózatok térségi tervezésének szükségességét. A területrendezésre vonatkozó, érvényes hazai jogszabályi háttér ismeretében megállapítottam, hogy a zöldút-tervezés a területrendezési tervezés szakaszaiba illeszthető, valamint azt, hogy a zöldúttervezés a térségi övezetképzés lehetőségének alkalmazásával, új térségi övezet képzésével és a térségi szintű területrendezési tervekben történő alkalmazásával a tervezési gyakorlatba bevezethető. A mintaterület példáján bemutattam, hogy a zöldút-hálózat a müszaki infrastruktúra hálózathoz kapcsolódó kerékpárút hálózatok kiegészítő eleme és alternatívája is lehet.

Hogyan hangolható össze a zöldút-tervezés az egyéb szabadtéri rekreációs lehetöségek tervezésével?

Válasz: A zöldút-tervezés céljai rokoníthatók a gyalogos, a kerékpáros és a lovas útvonalak és úthálózatok tervezési céljaival. A zöldút-tervezés újszerüsége a többféle rekreációs használatra alkalmas útvonalak együttes térbeli tervezése olyan tájszerkezeti elemek területén, amelyek többféle rekreációs útvonal számára egyaránt kedvező, illetve vonzó lehetőséget jelentenek. Ezért zöldutak létrehozhatók meglévő gyalogos, kerékpáros útvonalak bővítésével, azok további müszakizöldfelületi fejlesztésével, ugyanakkor tervezhetők új rekreációs szerepű útvonalként is.

Hogyan hangolható össze a zöldút-tervezés az ökológiai folyosók védelmével, illetve fejlesztésével?

Válasz: A zöldutak sajátos jellemzője, hogy a rekreációs szerepü útvonalak nem a müszaki infrastruktúra létesítményeihez, hanem a természetes és a természetközeli vonalas tájelemekhez kötődnek. A természetes és természetközeli területek jelentős része olyan folyó-, patak- és tóparti terület, amelyek a Nemzeti Ökológiai Hálózatban ökológiai folyosókként szerepelnek. A zöldúttervezés egyik lehetősége az ökológiai folyosók rekreációs szerepü fejlesztése az ökológiai szempontok figyelembe vételével. A mintaterület példáján bemutattam, hogy az általam javasolt 'zöldút kialakítására alkalmas térségi övezet' sok esetben az 'ökológia folyosó' térségi övezetével részben átfedésbe kerül, annak 'ökológiai pufferterület'-tel történő bővítését jelenti.

Hogyan bövithetik a civil zöldút mozgalom eredményei az olmstedi zöldút modellre alapozható tájépitészeti tervezési lehetőségeket?

Válasz: A civil zöldút mozgalmak által kijelölt zöldutak értékes helyismereten alapulnak. A 
civil zöldutak általában beavatkozás nélkül is alkalmasak gyalogos és/vagy kerékpáros közlekedésre, mert kijelölésük meglévő, rekreációs céllal használható utak kiválasztásával történik. A civil zöldutak előnye, hogy a helyi társadalom számára anyagi beruházás nélkül is használhatók. Hátrányuk az, hogy szélesebb körü - turisztikai célú - rekreációs használatuk várhatóan tájhasználati konfliktusokkal jár (gazdálkodási és rekreációs használatból adódó eltérő kialakítási és fenntartási igények, anyagi háttér kérdése stb.) A mintaterület példáján bemutattam, hogy egy civil szervezet által javasolt útvonal hálózat elemei az olmstedi zöldút modellre alapozott tájépítészeti tervezés értékes alapját vagy kiegészítését jelentik. A helyismereten alapuló útvonal kijelölések jelentőségét tájtörténeti elemzéssel alátámasztottam.

\subsection{Tézisek}

\section{1. tézis:}

\section{A magyarországi zöldút-tervezés történeti elözményeinek feltárása}

Feltártam a magyarországi zöldút-tervezés történeti előzményeit a tájépítészeti szakirodalomból megismert előzmények ismeretében. Feltártam, hogy a hazai városi parksétányok tervezése, a barokk kastélyparkok lovaglóútjainak kialakítása, a gyalogos turistautak tervezése, és különösen a természetes és a természetközeli környezetben vezető kerékpárutak és gyalog-kerékpárutak tervezése tervezéstörténeti előzménye a hazai zöldút-tervezésnek, és e tervezési előzményre müködőképes zöldút-hálózat telepíthető.

\section{A magyarországi zöldút-tervezés történeti elözményének emblematikus példái:}

- a budapesti Andrássy út

- a budapesti Duna korzó

- a barokk kastélykertek lovaglóútjai

- a magyarországi turistaút hálózat

- a zarándok útvonalak

- a Duna menti EuroVelo 6 kerékpáros útvonal

- a Tisza menti EuroVelo 11 kerékpáros útvonal

- a Balaton körüli kerékpárút

- a Fertö tó körüli kerékpárút

- a Velencei-tó körüli kerékpárút

— az egykori "Vasfüggöny" menti Eurovelo 13 gyalog-kerékpárút

- a Séd-patak menti gyalog-kerékpárút és zöldfelületi fejlesztés 
- a Rákos-patak menti gyalog-kerékpárút és zöldfelületi fejlesztés

- a Szilas-patak menti gyalog-kerékpárút és zöldfelületi fejlesztés

- az Általér menti kerékpárút

- a civil zöldutak

\section{Mintaterületi alátámasztás}

A Zsámbéki-medence területén a zöldút-tervezés történeti elözménye a Budavidék Zöldút Szövetség civil zöldút-hálózat javaslata (ld. 8. ábra).

\section{2. tézis:}

A magyarországi területrendezési és településrendezési tervezésbe integrálható zöldút definíció megalkotása

Áttekintettem a tájépítészeti szakirodalomban meghatározó zöldút definíciókat, majd kiemeltem a Frederick Law Olmsted tervezési koncepcióján alapuló zöldút modell sajátos térbeli jellemzőit a tájépítészeti kutatások és a gyakorlatban megvalósult példák alapján. Bemutattam a zöldút-tervezés lehetőségét és újszerüségét a mintaterületül választott Zsámbéki-medence területén, majd a hazai jogszabályi háttérhez illeszkedve megalkottam a területrendezési és településrendezési tervezési rendszerbe illeszthető zöldút definíciót.

Definiciójavaslatom: A zöldút többféle rekreációs használatra tervezett út, amely a kapcsolódó zöldfelületekkel együtt térségi szintü, hierarchikus hálózatot alkot. A zöldutak létesitésének fö területei a vízpartok, a felhagyott vasúti nyomvonalak, a történelmi útvonalak, a mezögazdasági útként fennmaradt hagyományos településközi utak és egyéb sajátos, rekreációs és ökológiai szerep betöltésére egyaránt alkalmas vonalas tájelemek.

\section{Mintaterületi alátámasztás}

A Zsámbéki-medence területére javasolt zöldút-hálózat újszerüsége a gyalogos és a kerékpáros használatra közös nyomvonalakon tervezett úthálózat, amelynek fö gerincét a Békás-patak, valamint a Budajenő és Páty közötti hagyományos településközi út jelenti. A javasolt zöldút hálózat alternativát jelent a térségi és a települési tervekben javasolt föút menti kerékpárutak mellett, és kiegészíti a meglévö gyalogos turista útvonalak hálózatát (ld. 15., 16., 17., 18. ábra).

\section{3. tézis:}

\section{A magyarországi zöldutak alapvetö térbeli lehetőségeinek meghatározása}

Feltártam a zöldutak és az egyfunkciós rekreációs útvonalak (gyalogos és kerékpáros útvonalak), valamint a zöldutak és az ökológiai folyosók hasonló, illetve eltérő szerepeit és térbeli kialakítási 
lehetőségeit. Megállapítottam, hogy a zöldút modell meghatározó jellemzői alapján vannak olyan megvalósult többfunkciós rekreációs útvonalak Magyarországon, amelyek zöldútnak tekinthetők. Ezek további beavatkozás nélkül vagy szükséges fejlesztésekkel a zöldút-hálózatok részei lehetnek. Megállapítottam, hogy egyes gyalogos és kerékpáros útvonalak rekreációs szerepeik bővítésével és zöldfelületi-ökológiai fejlesztéssel zöldúttá alakíthatók. Megállapítottam, hogy egyes ökológiai folyosók rekreációs célú zöldfelületi fejlesztéssel zöldúttá alakíthatók. A mintaterület példáján bemutattam, hogy zöldutak új tájelemként is tervezhetök a rekreációs és az ökológiai célú fejlesztések összehangolásával.

A magyarországi zöldutak létesitésének alapvetö térbeli lehetöségei:

- a meglévö vagy tervezett többfunkciós, ökológiai szerepet is betöltö rekreációs útvonalak zöldút-hálózatokhoz kapcsolása zöldútként

— a meglévő vagy a tervezett egyfunkciós rekreációs útvonalak zöldúttá fejlesztése zöldfelületiökológiai tervezéssel

- a meglévö vagy a tervezett ökológiai- és zöldfolyosók zöldúttá alakitása rekreációs célú tervezéssel

- új zöldutak tervezése a zöldút modell alkalmazásával

\section{Mintaterületi alátámasztás}

A Zsámbéki-medence területére általam javasolt zöldút-hálózat térbeli lehetőségei a következők:

- a Budavidék Zöldút Szövetség kezdeményezésére gyalogos és kerékpáros használatra feltárt, kettős fasorral kísért hagyományos településközi út Budajenö és Páty között,

- a Békás-patak és a Budajenöi-patak menti ökológiai folyosó és a biatorbágyi felhagyott vasút vonal menti zöldfolyosó rekreációs célú tervezéssel fejleszthetö szakaszai,

— új zöldút szakaszok a Békás-patak mellékpatakjai és egyes mezögazdasági utak mentén (ld. 15. ábra).

\section{4. tézis:}

\section{A zöldút-tervezési feladatok meghatározása a magyarországi zöldutak tipizálásával}

Megállapítottam, hogy adott tervezési területre vonatkozó zöldút-tervezési feladatok meghatározásához a zöldutak tipizálása szükséges. A fó zöldút típusokat a zöldutak térbeli elhelyezkedése és térségi szerepük meghatározásával állapítottam meg. Tipizálási javaslatomban meghatároztam az általános, közös feladatokat, valamint az egyes zöldút típusokra vonatkozó sajátos tervezési feladatokat. A kétféle szempont szerint típusonként meghatározott feladatokat a zöldutak tervezése során együttesen kell kidolgozni. A Zsámbéki-medence területére javasolt térségi szintü zöldút-hálózat koncepció javaslatom példáján bemutatom egy konkrét zöldút-hálózaton belül 
megjelenő zöldút típusokat.

A tipizálás rendszere

1. Elhelyezkedés szerinti zöldút típusok:

- vízparti zöldutak

- felhagyott vasúti nyomvonal menti zöldutak

- történelmi útvonalak menti zöldutak

- hagyományos településközi utak menti zöldutak

— települési zöldutak

- egyéb zöldutak

2. Térségi szerep szerinti zöldút típusok:

- országos zöldutak

- térségi zöldutak

- helyi zöldutak

\section{Mintaterületi alátámasztás}

A Zsámbéki-medence területére általam javasolt zöldút-hálózat térségi jelentőségü elemei a Békáspatak és a Füzes-patak menti vízparti zöldút típusba sorolható szakaszok, a Budajenö és Páty közötti hagyományos településközi zöldút típusba sorolható szakaszok, valamint egyes települési zöldút típusba sorolható szakaszok Budajenőn, Pátyon és Biatorbágyon. A térségi szerepü zöldútszakaszok a Békás-patak mentén összekapcsolhatók az országos szerepü zöldúttá alakítható Duna menti kerékpáros útvonallal. A javasolt helyi szerepü zöldút szakaszok között vannak felhagyott vasúti nyomvonal menti zöldút típusba, települési zöldút típusba és egyéb zöldút típusba sorolható szakaszok (ld. 18. ábra).

Az általam meghatározott zöldút típusokhoz tartozó tervezési feladatokat a 4. táblázat táblázat tartalmazza (94.old.)

\section{5. tézis:}

\section{A zöldút-tervezés helyének meghatározása a magyarországi terülletrendezési tervezésben}

Meghatároztam a zöldút-tervezés munkarészeinek integrálási lehetőségét az országos, a megyei, valamint a kiemelt térségi szintű tervezési folyamatokba a területrendezési tervek tartalmi követelményeit meghatározó 218/2009. (X.6.) Korm. rendeletben foglalt elöírásokra alapozva.

Megállapitottam, hogy a zöldút-tervezés beilleszthető a területrendezési tervek Vizsgálat és Program munkarészeibe, a Területi hatásvizsgálat és a Környezeti hatásvizsgálat folyamatába. A 
térségi szerepü zöldutak a térségi övezeti tervekben, zöldút kialakitására javasolt térségi övezetként megjelenithetök. Az övezetképzés biztosithatja összefüggö, hierarchikus rendszert alkotó zöldúthálózatok kialakitását. Megállapítottam, hogy zöldút-tervezés a megalapozó munkarészek között önálló munkarészként is megjelenhet, ezzel is elösegitve az országos és a térségi szinten meghatározott zöldutak további, részletes tervezését a településrendezési tervezés során.

A zöldút-tervezési munkarészek integrálási lehetőségének tartalmi elemeit a 2. táblázat tartalmazza. (83.old.)

\section{Mintaterületi alátámasztás}

A Zsámbéki-medence területére javasolt térségi szintü zöldút-hálózat integrálása a területrendezési tervezési folyamatba a Budapesti Agglomeráció - mint kiemelt térség - Területrendezési Tervébe vagy Pest megye Területrendezési Tervébe illeszthetö, a 218/2009. (X.6.) Korm. rendeletben szereplö munkarészek szerint.

\section{6. tézis:}

\section{A "zöldút kialakítására javasolt térségi övezet" képzésének megalapozása}

Megállapítottam, hogy a zöldutak területhasználati szempontból változatlan, de a kezelés, illetve a használati módok tekintetében eltérő kezelést igénylő területeknek tekinthetők, ezért optimális kialakításukat, fejlesztésüket és fenntartásukat önálló térségi övezet lehatárolása biztosíthatja.

\section{"Zöldút kialakitására javasolt térségi övezet" képzésének célja:}

Az új térségi övezet képzésének célja elsősorban olyan, tájszerkezeti szempontból értékes tájelemek (vizparti területek, felhagyott vasútvonalak, történelmi útvonalak, mezögazdasági útként fennmaradt egykori településközi utak stb.) és környezetük megörzése és védelme, amelyek többféle rekreációs használat számára egyaránt vonzó lehetőséget jelentenek. Az övezetképzés célja másodsorban a zöldút kialakitására alkalmas vonalas tájelemek rekreációs lehetőségeinek feltárása és optimális zöldfelületi fejlesztése, amely térségi jelentöségü, hierarchikus rendszert alkotó, rekreációs és ökológiai szempontból egyaránt jelentös szerepü zöldút-hálózatok létrejöttét eredményezheti.

A "zöldút kialakitására javasolt térségi övezet" területére javasolt elöirások

A javasolt övezet területén érvényesitendő elöirások a rekreációs használat számára optimális müszaki-zöldfelületi megoldásoknak és az ökológiai értékek megörzésének összehangolását szolgálják.

— Az övezet területén biztositani kell többféle rekreációs használat számára alkalmas utak 
kialakitását és azok - keritéssel történö lezárás vagy gépjármü forgalom által meg nem szakitott - folyamatosságát;

- Az övezet területét a települési zöldfelületekhez kapcsolódóan kell tervezni, fejleszteni és fenntartani;

- Az övezetbe tartozó terület használatának (rekreációs használat, mezögazdasági használat) szabályait helyi rendeletben kell megállapitani.

A javasolt térségi övezet kialakitásához szükséges adatok

A javasolt térségi övezet lehatárolása tervezöi lehatárolással történhet, a következö adatok alapján:

- térségi szerkezeti terv,

— térségi ökológiai hálózat övezeti tervei,

- településrendezési tervek,

- történeti térképek,

- tájrégészeti kutatások eredményei,

- a helyi emlékezet és hagyomány,

- helyszini bejárások tapasztalatai.

Mintaterületi alátámasztás

A zöldút kialakitására alkalmas térségi övezet lehatárolását a Zsámbéki-mdence területén a Békáspatak, a Budajenöi-patak, a Füzes-patak, valamint a Budajenö és Páty közötti hagyományos településközi út mentén javasolom (ld. 19. ábra). 


\section{KÖVETKEZTETÉSEK ÉS JAVASLATOK}

\subsection{Következtetések}

A zöldút-tervezés elméleti alapjai szoros rokonságot mutatnak a magyarországi zöldfelületi rendszer tervezés elméleti alapjaival. A Frederick Law Olmsted tájépítészeti újítására visszavezethető zöldút modell és a hazai zöldfelületi rendszer tervezés alapgondolata közös: a vonalas és a területi zöldfelületi elemek összekapcsolása összefüggő rendszerré. A zöldút modellben hangsúlyos a természeti vagy természetközeli környezetben elhelyezkedő vonalas zöldfelületi elemek szerepe. A zöldút-tervezés sok esetben kiindulási alap a további zöldfelületi fejlesztések számára. A modell magyarországi alkalmazása ezért elősegítheti a zöldfelületek fejlesztését, illetve összefüggő zöldfelületi rendszerek kialakítását, valamint a zöldfelületi rendszerek táji léptékü kiterjesztését.

A zöldút modell lényegéhez tartozik, hogy a zöldutak olyan zöldfelületi elemek, amelyek többféle rekreációs - elsősorban gyalogos és kerékpáros - használatra alkalmas közös útvonal tervezését foglalják magukba egy-egy kiválasztott vonalas tájelem mentén. Ebből következik, hogy a zöldutak szélessége a táji adottságoktól függően változó. Egy zöldút nyomvonalon belül vannak keskenyebb és szélesebb szakaszok a szomszédos területhasználatoktól, illetve tulajdonosi viszonyoktól függően. A többféle rekreációs használat a térbeli adottságoktól függően megvalósulhat közös útvonalon vagy elválasztott rendszerben.

A zöldút-tervezés lényeges sajátossága, hogy célja a helyi, a térségi és az országos szintü zöldút-hálózatok összehangolt kidolgozása. A zöldút tervek kezdeményezése bármely tervezési szintről indulhat, de a térségi szintű tervezésre minden esetben szükség van. A települések közötti optimális zöldút nyomvonalak meghatározásához ugyanis minden esetben több települést érintő tájépítészeti vizsgálat és tervezés szükséges. Kutatásom eredményei alapján azt állítom, hogy Magyarországon a területrendezési tervezés törvényi szabályozással meghatározott rendszere biztosítja a térségi szintű zöldút-tervezés jogi alapjait. A területrendezési tervezés kormányrendelettel elöírt munkarészeibe a zöldút-tervezés munkarészei beilleszthetők. A zöldút terv térségi jelentőségü elemei a térségi övezeti tervekben új övezet képzésével ("zöldút kialakítására javasolt térségi övezet") megjeleníthetők. Ez azt is jelenti, hogy a területrendezés érvényes jogi szabályozása lehetővé teszi a zöldút-tervezés, mint új, térségi jelentőségű tájépítészeti javaslat befogadását. A zöldút-tervezés területrendezési tervezésbe való integrálási lehetősége egyben azt is jelenti, hogy a zöldút kialakítására alkalmas térségi övezet kijelölésének elfogadása esetén a zöldút továbbtervezési feladata a településrendezési tervezés folyamatában is megjelenik. A településrendezési tervekben megjelenő zöldút-tervezési javaslatok az objektum tervezés szintjén 
tovább finomíthatók.

A zöldút-tervezés a rekreációs célú és ökológiai szempontú tervezés együttes megvalósítását foglalja magába. Ezért a tervezés során figyelembe kell venni azokat törvényeket és egyéb jogszabályi előírásokat, tervezési útmutatókat, müszaki előírásokat, amelyek a gyalogos útvonalak, a kerékpárforgalmi úthálózatok kialakítására, valamint a természet- és a környezetvédelmi elvek megvalósítására, az ökológiai állapot megörzésére és fejlesztésére vonatkoznak.

Kutatásom során megállapítottam, hogy Magyarországon is felismerhetők a zöldút-tervezés tervezéstörténeti előzményei. A zöldút-tervezési feladatok meghatározásánál a tervezési előzményeket figyelembe kell venni. Elsősorban azokat a létesítményeket kell bevonni a tervezésbe, amelyekről a zöldút modell mintáján megállapítható, hogy zöldútnak tekinthetők vagy fejlesztéssel zöldúttá alakíthatók. Ezeket az országos és térségi szintü zöldút-tervezés során a kialakítandó zöldút-hálózat részeinek kell tekinteni. Ilyenek a Duna, a Tisza, a Dráva, a Balaton, a Fertő tó és a Velencei tó menti kerékpáros és gyalog-kerékpáros útvonalak. Megvalósult, térségi szerepű zöldútnak kell tekinteni a Séd-patak, a Rákos patak, a Szilas patak menti zöldfelületi fejlesztéssel párosuló gyalog-kerékpárutakat, valamint részben megvalósult zöldútnak az Által-ér menti kerékpárutat.

A magyarországi zöldút-tervezés újszerüsége a zöldútnak vagy zöldú-tervezési előzménynek tekinthető létesítmények szükség szerinti fejlesztése a zöldút modell alapján, valamint új zöldutak és zöldút-hálózatok tervezése az ország teljes területén úgy, hogy létrejöjjön egy hierarchikus felépítésű zöldút-hálózat, amely mint egy érrendszer kapcsolja össze a települések beépített és nem beépített részeit, illetve az ország térségeit egymással. Az érrendszer hasonlatnak megfelelő zöldúthálózat teljes körü kialakítása azt is eredményezi, hogy a települések minden pontjáról gépkocsi használat nélkül, gyalogosan vagy kerékpárral a természetes vagy a természetközeli környezetben található zöldutak elérhetők.

A zöldutak létesítése egyrészt kiegészíti a kerékpárút- és a gyalogos turistautak hálózatát, másrészt alternatívája lehet azoknak. A zöldút modell alapján tervezhető zöldutak kiválthatják a főtakhoz kapcsolódó kerékpárutakat azáltal, hogy a nyomvonal választás nem a müszaki infrastruktúra közlekedési létesítményeihez, hanem elsősorban a vízparti, a felhagyott vasútvonalak menti és a hagyományosan kialakult településközi utakhoz, történelmi útvonalakhoz kötődik. A zöldút-tervezés a mezőgazdasági területeken mintegy "mederbe tereli" a rekreációs használatokat, és ezzel a mezőgazdasági területeken folyó gazdálkodási tevékenység és a rekreációs használat közötti tájhasználati konfliktusokat minimalizálja.

A zöldút-tervezés kiemelkedő szerepet tölthet be a beépített és a nem beépített területek zöldfelületei közötti kapcsolat megteremtésében, aminek településszerkezeti és településökológiai 
szerepe egyaránt jelentős. A zöldút-tervezéshez kapcsolódóan olyan értékes település- és tájszerkezeti elemek megőrzése és hasznosítása történhet meg, mint a mezőgazdasági útként fennmaradt településközi utak, kereskedelmi- és zarándok útvonalak, mezővédő erdősávok, emlékfasorok stb.

\subsection{Javaslatok}

Kutatási eredményeim gyakorlati alkalmazása céljából az első lépés az általam javasolt zöldút fogalom szakmai konszenzussal történő elfogadása vagy szükség szerint további finomítása lehet.

A zöldút-tervezés területrendezési tervezésben történő megjelenítése a zöldút modell általános magyarországi alkalmazását szolgálná. Ez azt jelenti, hogy azokban a térségekben, ahol egyelőre nincs tervezési előzménye a zöldút-tervezésnek, illetve nem fogalmazódik meg szándék zöldúthálózatok tervezésére, a területrendezési tervezés előkészítené az országos és a térségi zöldúthálózatok tervezését. A zöldút-tervezésnek a területrendezési tervezésbe történő integrálása biztosítaná az optimális zöldút-hálózatok tervezését és a zöldút alternatívák összehasonlítását az egyéb szakági tervjavaslatokkal országos és térségi szinten.

A zöldút-tervezés területrendezési tervezésben történő megjelenítését elsőként a kiemelt térségi (Budapesti Agglomeráció, Balaton Kiemelt Üdülési Térség) és a megyei tervezés szintjén javasolom, mert a többféle rekreációs használatra alkalmas zöldutak létesítése elsősorban a nagy népsürüségű vagy a turizmus számára kiemelt vonzást jelentő térségekben indokolt. Ezen a szinten a legfőbb feladat a térségi zöldút-hálózatok optimális nyomvonalainak meghatározása a javasolt zöldút-tervezési metodika szerint: a vízparti területek, a felhagyott vasútvonalak menti területek, a történelmi útvonalak, a hagyományos településközi utak és az egyéb, zöldút kialakítására alkalmas vonalas tájelemek menti zöldút lehetőségek elemzésével.

Javasolom a már megkezdett, a zöldút modellnek megfeleltethető országos jelentőségü tervek (különösen a Duna, Tisza, Balaton menti kerékpáros és gyalog-kerékpáros útvonalak, az egykori "Vasfüggöny" menti gyalog-kerékpáros útvonalak) további tervezésében a zöldfelületi tervezés megjelenítését az útvonalakhoz kapcsolható zöldfelületek, valamint azok rekreációs és ökológiai fejlesztése céljából. További folyó-, patak- és tóparti területek zöldút modellnek is megfelelő tervezése az eddig megvalósult jó példák (Séd-patak, Rákos-patak, Szilas patak, Általér menti fejlesztések) alapján települési szinten kezdeményezhető. A felhagyott vasút vonalak menti, a történelmii útvonalak menti, a hagyományos településközi utak menti és az egyéb zöldút lehetőségek feltárása további kutatási feladatokat jelenthet.

A lehetőségektől és a szándékoktól függően a zöldút modell alkalmazása településre, településcsoportra vagy járásra vonatkozóan is történhet, és lehetőség van a zöldút modell objektum 
szintü alkalmazására is. Ahhoz azonban, hogy országos szinten összehangolt, "az egész országot mintegy érrendszerként átszövő" összefüggő zöldút-hálózat jöhessen létre, a zöldút-tervezésnek a területrendezési és a településrendezés folyamatába történő integrálásra van szükség. 


\section{ÖSSZEFOGLALÁS}

Kutatásom célja a magyarországi zöldút-tervezés tájépítészeti metodikájának megalapozása volt. Alapvető feladatnak tartottam a zöldút fogalomnak a tájépítészeti szakirodalomban elfogadott jelentéstartalmára alapozott, ugyanakkor a magyarországi tervezési gyakorlatba illeszthető meghatározását. Megállapítottam, hogy a szakirodalomi publikációkban a zöldút-tervezés tájépítészeti alapját széles konszenzussal Frederick Law Olmsted 1894-ben tervezett 'Emerald Necklace' elnevezésü parkrendszerében megnyilvánuló tervezési gondolat jelenti. Az olmstedi gondolat XX. századi, táji léptékű kiterjesztése zöldút modellként jelenik meg a szakirodalomban.

A szakirodalmi források és az 'Emerald Necklace' személyes bejárásának tapasztalatai alapján megállapítottam a zöldút modell legfőbb ismérveit, majd vizsgáltam a modell alkalmazhatóságát a hazai tájépítészeti tervezésben. Feltártam, hogy a hazai városi parksétányok tervezése, a barokk kastélyparkok lovaglóútjainak kialakítása, a gyalogos turistautak tervezése, és különösen a természetes vagy természetközeli környezetben vezető kerékpárutak és gyalog-kerékpárutak tervezése tervezéstörténeti előzménye a hazai zöldút-tervezésnek, és e tervezési elözményre müködőképes zöldút-hálózat telepíthető.

Ezt követően a kutatási mintaterületül választott Zsámbéki-medence területére vonatkozóan vizsgáltam a zöldút modell alkalmazásának lehetőségét. A Zsámbéki-medencében helyi társadalmi kezdeményezéssel kijelölt zöldút-hálózatra, mint tervezéstörténeti előzményre alapozva, a zöldút modell tájépítészeti ismérvei alapján megfogalmaztam saját javaslatomat az optimális zöldút hálózat koncepciójára. A koncepció által vázolt zöldút-hálózat szakaszolásával megalkottam a zöldutak tipizálási rendszerét. A tipizálás alapja a zöldutak elhelyezkedés, illetve térségi szerep szerinti típusainak meghatározása. Tipizálásom alapján a zöldutak tervezése a kétféle szempont szerint meghatározható zöldúttípusokra vonatkozó tervezési feladatok együttes alkalmazásával történhet. Az elhelyezkedés szempontjából meghatározott klasszikus zöldút típusok - vízparti, felhagyott vasútvonalak menti, történelmi utak menti zöldutak - meghatároztam egy sajátos magyar tájszerkezeti elem, a mezőgazdasági útként fennmaradt hagyományos településközi út menti zöldúttípust.

A zöldút-tervezés gyakorlati bevezetése érdekében elemeztem a zöldút-tervezés integrálhatóságát a hazai területrendezési és településrendezési tervezés rendszerébe. Megállapítottam, hogy a 218/2009. (X.6.) Korm. rendeletben az országos és a térségi területrendezési tervek készítésére előírt munkarészekbe a zöldút-tervezés beilleszthető. Javaslatomban megfogalmaztam a 'zöldút kialakítására alkalmas térségi övezet' képzésének alapjait.

A zöldút-tervezés területrendezési tervezésbe való integrálási lehetősége egyben azt is jelenti, 
hogy a zöldút kialakítására alkalmas térségi övezet kijelölésének elfogadása esetén a zöldút továbbtervezési feladata a településrendezési tervezés folyamatában is megjelenik. A településrendezési tervekben megjelenő zöldút-tervezési javaslatok az objektum tervezés szintjén tovább finomíthatók.

Kutatási eredményeim gyakorlati alkalmazása céljából az első lépés az általam javasolt zöldút fogalom szakmai konszenzussal történő elfogadása vagy szükség szerint további finomítása lehet.

A zöldút-tervezés területrendezési tervezésben történő megjelenítését elsőként a kiemelt térségi (Budapesti Agglomeráció, Balaton Kiemelt Üdülőkörzet) és a megyei tervezés szintjén javasolom. 


\section{IRODALOMJEGYZÉK}

\section{Nyomtatott és elektronikus szakirodalom}

Könyvek, könyvfejezetek

1. Bárcziné Kapovits, J. [2014]: Tervezéstörténeti áttekintés a magyarországi zöldút-tervezés megalapozásához. In: Csemez Attila (szerk): Tájakadémia IV. Időszerü tájrendezési feladatok. Budapest. pp. 37-48.

2. Bárcziné Kapovits, J.-Molnár A. J. [2012]: Nyomvonalvezetési megfontolások, helyi kezdeményezések szerepe zarándokutaknál. In: Filepné Kovács Krisztina (szerk): A Mária út hálózat és kialakítása. Budapesti Corvinus Egyetem, Budapest. pp. 47-54.

3. Csemez, A. [1996]: Tájtervezés, tájrendezés. Mezőgazda Kiadó. Budapest.

4. Eco, U.[1992]: Hogyan írjunk szakdolgozatot? Budapest, Gondolat.

5. Fein, A. [1968]: Landscape into Cityscape. New York. pp. 157-158.

6. Flinck, Ch.-A.; Searns, R. M [1993]: Greenways. Washington, 1993.

7. Gerzánics, A. [2003]: A területrendezési tervek készítését meghatározó jogszabályok. In: Csemez, A. (szerk.): Száz éve született Ormos Imre. Szent István Egyetem Tájépítészeti, védelmi és - fejlesztési Kar, Budapest. pp. 97-102.

8. Gerzánics, A. [2013]: Területrendezéshez kapcsolódó tájrendezés. In: Konkoly-Gyuró Éva (szerk.):Környezettervezés. Budapest: Mezőgazda Kiadó. pp. 181-204.

9. Greenway Handbook [2002]. Natural England.

10. Hellmund, P. C:-Smith, D.S.[2006]: Designing Greenways, Washington.

11. Jongmann, R.; Pungetti, Gloria [2004]: Introduction: Ecological networks and greenways, in: Ecological Networks and Greenways. New York. pp.1-6.

12. Konkoly-Gyúró, É.(szerk) [2013]: (szerk.):Környezettervezés. Budapest: Mezőgazda Kiadó

13. Little, C. [1990]: Greenways for America. Maryland. 1990.

14. Sallay, Á.-Bárcziné Kapovits, J.[2011]: Zöldút-tervezés, mint a turizmusfejlesztés eszköze (Tájépítész és civil együttmüködés a Zsámbéki-medencében). In: Michalkó Gábor, Rátz Tamara (szerk): A turizmus dimenziói: humánum, ökonómikum, politikum (Turizmus Akadémia sorozat 5. kötete). Kodolányi János Főiskola, Székesfehérvár. pp. 278-291.

15. Szilágyi, K. [2003]: A zöldterülettől a zöldfelületi és szabadtér rendszerig, in: Száz éve született Ormos Imre, Budapest.

16. Szilágyi, K., Almási, B., Hutter, D., Szabó, L. [2012]: A várostervezés szürke-zöld 
dilemmái. A városi térszerkezet alakítása és az élhető város elve. in: Fenntartható fejlődés, élhető régió, élhető települési táj. Budapest.

17. Whyte, W. [1959]: Securing Open Spaces for Urban America. www.gpo.gov

18. Whyte, W. [1968]: The Last Landscape. New York, 1968.

Tudományos értekezések, egyetemi jegyzetek, tanulmányok, állásfoglalás

19. Ahern, J. [2004]: Greenways in the USA: theory, trends and prospects, in: Ecological Networks and Greenways, Cambridge Universitity, New York, 2004 pp. 34-53

20. Almási, B. [2007]: A zöldhálózat tervezés metodikai fejlesztése Budapest peremkerületének példáján, Doktori (Phd) értekezés, Budapest.

21. Báthoryné Nagy, I. R. [2007]: Kisvízfolyások tájrehabilitációjának rendezési elvei és módszere, Doktori $(\mathrm{PhD})$ értekezés, Budapest.

22. Bischoff, A.. [2004]: The New Generation of Greenway Planning. people.umass.edu/abischoff/newgreenways

23. Filepné Kovács, K. [2013]: Tájhasználati szempontok a vidéki térségek versenyképességének értelmezéséhez. Doktori $(\mathrm{PhD})$ értekezés. Budapest.

24. Kollányi, L. [2011]: A Budapesti Agglomeráció Területrendezési Terve felülvizsgálatának és módosításának Környezeti Vizsgálata. Budapest.

25. Kosztka, M. [2010]: Mezőgazdasági infrastruktúra alapjai. Nyugat-magyarországi Egyetem. www.tankonyvtar.hu

26. Sallay, Á.-Bárcziné Kapovits, J. [2010]: Greenways = Zöldutak. In: Sallay Ágnes (szerk): Tájtervezés és területfejlesztés. Egyetemi jegyzet, Budapesti Corvinus Egyetem, Tájépítészeti Kar, Budapest. pp. 193-203.

27. Schneller, I. [2013]: Opponensi vélemény a Budapesti Agglomeráció Területrendezési Tervéről szóló 2005. évi LXIV. tv. módosításának tervezetéről. http://fiatalurbanista.hu/publikaciok/dr-schneller-istvan-opponensi-velemeny-budapestiagglomeracio-teruletrendezesi-terverol

28. Tomcsányi, P. [2000]: Általános kutatásmódszertan. SZIE, Gödöllő, 2000.

29. Fülöp, S. [2011]: A jövő nemzedékek országgyülési biztosának állásfoglalása az új Alaptörvény környezetvédelmi és fenntarthatósági rendelkezéseiből eredő állami felelősségről. JNO-258/2011

\section{Folyóiratcikkek}

30. Bárcziné Kapovits, J. - Kollányi, L. (2012): A Mária Út a Zsámbéki-medencében. Vidék és 
Gazdaság. 2012. különszám. pp.37-39.

31. Bárcziné Kapovits, J. - Sallay, Á. - Csemez, A. (2011): Landscape design tasks based on the Budavidék Greenway. Acta Universitatis Sapientiae. Agriculture and Environment Supplement. Cluj-Napoca. pp. 68-79.

32. Bárcziné Kapovits, J. (2011): Zöldutak lehetséges szerepe a táj- és településtervezésben, a zöldút fogalom tervezéstörténeti áttekintése alapján. 4D Tájépítészeti és kertmüvészeti folyóirat. 24. pp.2-17.

33. Bárcziné Kapovits, J.-Csemez, A.-Sallay, Á. (2009): Tájépítészeti kutatási feladatok a magyarországi zöldutak fejlesztésénél. Tájökológiai Lapok 2. Szent István Egyetem, Gödöllö. pp. 465-471.

34. Fabos, J. Gy. (2004): Greenway planning in the United States: its origin and recent case studies, Landscape and Urban Planning, 68. pp. 321-342

35. Fabos, J.Gy.(1995): Introduction and overview: the greenway movement, uses and potentials of greenways. Landscape and Urban Planning, 33. pp. 1-13.

36. Grove, N. (1990): Greenways: Path to the Future. In: National Geographic, 1990. No.6.

37. Hutter, D.-Almási, B.-Bárcziné Kapovits, J. (2014): Zöldútfejlesztési lehetőségek felhagyott vasútvonalak mentén - Tájépítész hallgatók ötlettervei a biatorbágyi régivasút környezetére. 4D Tájépitészeti és kertmüvészeti folyóirat.34. pp. 24-41.

38. Ribeiro, L.-Barao, T. (2006): Greenways for recreation and maintenance of landscape quality: five case studies in Portugal. Landscape and Urban Planning, 76.pp. 79-97.

39. Schuchmann, P. (2008): A zöldövezet fejlesztés lehetőségei a Budapesti agglomerációban, in: Falu Város Régió. 2008/1, Budapest.

40. Schuchmann,P. (2007): A tájtervezés területrendezési tervezéshez kapcsolódó lehetőségei és feladatai. 4D Tájépitészeti és kertmüvészeti folyóirat. 5. pp. 13-20.

41. Searns, M. (1995): The evolution of greenways as an adaptive urban landscape form. Landscape and Urban Planning. 33 (1995) pp. 65-80.

42. Szilágyi, M. (2012): Római utak a középkori Dunántúlon - Régészeti és történeti kutatások módszerei és lehetőségei. Magyar régészet. Online magazin. pp.1-4. www.academia.edu/2489500

43. Taylor, J.-Paine, C.-Fitz Gibbon, J. (1995): From greenbelt to greenways. Landscape and Urban Planning. 33 pp. 47-64.

44. Thomas, D. (1963): London's Green Belt: The evolution of an idea. The Geographical Journal. Vol. 129, No. 1. pp. 14-24. 
45. Tózsa, I. (2002): A káros urbanizáció. Tér és társadalom. Elektronikus folyóirat.16.évf. pp. 1-16.http://tet.rkk.hu/index.php/TeT/article/view/834/1664

46. Turner, T. (1995): Greenways, blueways, skyways and other ways to a better London. Landscape and Urban Planning. 33. pp. 269-282.

47. Turner, T. (2006): Greenway planning in Britain: recent and future plans. Landscape and Urban Planning.76. pp. 240-251.

48. Zube, E. H. (1995): Greenways and the US National Park System. Landscape and Urban Planning. 33. pp. 17-25.

\section{Konferenciakiadványok}

49. Bárcziné Kapovits Judit (2012): A zöldút-tervezés tájépítészeti keretei a Zsámbéki-medence példáján. V. Magyar Tájökológiai Konferencia, Sopron, 2013. pp. 201-207.

50. Bárcziné Kapovits, J.-Csemez, A.- Sallay, Á. (2011): Opportunities for greenways in Hungary based on the example of the Budavidék Greenway. Chinese - European cooperation for a longterm sustainaibility. 10-11 November 2011, Budapest. http://korny.uni-corvinus.hu/corvinus.hu/cneucoop_fullpapers/s1/juditbarczinekapovits.pdf

51. Csemez A.; Magyar V. (2013): Teljesítménytúra = honismeret és sport? Tájtudomány és tájtervezés. V. Magyar Tájökológiai Konferencia. Konferenciakiadvány. Sopron, 2013.

52. Csemez A.; Magyar V. (2013): Teljesítménytúra = honismeret és sport? Tájtudomány és tájtervezés. V. Magyar Tájökológiai Konferencia. Konferenciakiadvány. Sopron, 2013.

53. Csemez A.(2010): Greenway development possibilities in Hungary; Flood protection banks and abandoned railway lines in greenway development. Proceedings of Fabos Conference on Landscape and Greenway Planning 2010, Budapest.

54. Csemez, A.; Bárcziné Kapovits, J. (2013): Opportunities for greenways through development of ecological and green corridor landscape planning in Hungary. In: Fábos, J.G. Lindhult, M., Ryan, R.L., \& Jacknin, M. (Eds). 2013. Proceedings of Fábos Conference on Landscape and Greenway Planning 2013: Pathways to Sustainability. University of Massachusetts, Amherst, April 12-13, 2013. Full papers. pp. 452-460.

55. Kollányi, L. (2014): Zarándokturizmus, zöldutak tervezési szempontjai. Savaria Urbaniszikai Nyári Egyetem. 2014. június. Előadás. www.sune.hu

56. Murphy, D.- Murek, D.(2010): Central European Greenways - designing International of Sustainable Developments, Proceedings of Fabos Conference on Landscape and Greenway Planning 2010, Budapest, pp.63-71. 
57. Ribeiro, L.-Dias T. (2010): Improving Small Cities Competitiveness through Greenway Planning and Design: Vila-Franca de-Xira case study, Lisboa Metropolitan area, Portugal, Proceedings of Fabos Conference on Landscape and Greenway Planning 2010, Budapest, pp.71-79.

Egyéb kiadványok, egyesületi honlapok

58. Budai, K. (szerk).: Zöldútravaló, Ökotárs Alapítvány, Budapest

59. Foltányi, Zs. (szerk.) (2005): Zöldutak Magyarországon, Ökotárs Alapítvány, Budapest, 2005

60. http://hu.wikipedia.org/wiki/Magyarország_vasúttörténete

61. http://magyaryterv.etata.hu/telepulesrendezes/kerekparut/muleiras.htm

62. http://www.isaszeg.hu/content/egyuttmukodes_a_rakos_patak_menti_kerekparut_megvalosi tasaert

63. Molnár, A. (szerk.) (2014): Turistaúthálózat és jelzésrendszer. Szakmai füzetek. www.termeszetbarat.hu

64. www.bvz.hu

65. www.sinibicikli.hu

66. www.zome.hu

\section{Térképi adatbázisok}

67. Az első katonai felmérés (1763-1785). Hadtörténeti Térképtár, Budapest.

68. A második katonai felmérés (1806-1869). Hadtörténeti Térképtár, Budapest.

69. A harmadik katonai felmérés (1869-1887). Hadtörténeti Térképtár, Budapest.

70. Digitális topográfiai térkép, 2000. FÖMI adatbázis

71. Ortofotók, 2000. FÖMI adatbázis

72. Turistaútvonalak. www.turistautak.hu

73. Felszínborítási adatok. CORINE 2006. adatbázis

74. Földhivatali térképek. www.takarnet.hu Jogszabályok

75. 1996. évi XXI. törvény a területfejlesztésről és a területrendezésről.

76. 1997. évi LXXVIII. törvény az épített környezet alakításáról és védelméröl.

77. 2003. évi XXVI. törvény az országos Területrendezési Tervről.

78. 2005. évi LXIV. törvény a Budapesti Agglomeráció Területrendezési Tervéről.

79. 218/2009. (X.6.) Korm. rendelet a területfejlesztési koncepció, a területfejlesztési program 
és a területrendezési terv tartalmi követelményeiről, valamint illeszkedésük, kidolgozásuk, egyeztetésük, elfogadásuk és közzétételük részletes szabályairól.

80. 253/1997. (VII.18.) Korm. rendelet az országos településrendezési és építési követelményekröl 


\section{ÁBRA- ÉS TÁBLÁZATJEGYZÉK}

\section{Ábrajegyzék}

1. ábra: Olmsted parkrendszer terve Boston városi közparkjától a Franklin parkig, 1894. 19

2. ábra: Zöldút hálózat koncepció a New England régió területére (forrás: www.umass.com).

3. ábra: Meglévő és tervezett rekreációs útvonalak és zöldterek New England régió területén (forrás: www.umass.hu).

4. ábra: A zöldút modell hazai alkalmazhatóságának vizsgálati szempontjai (saját szerkesztés). 30

5. ábra: A Zsámbéki-medence térségi elhelyezkedése és áttekintő térképe (saját szerkesztés)

6. ábra: Hagyományos patak menti utak a Békás-patak és a Budajenői-patak mentén (saját szerkesztés, forrás:

Első katonai felmérés, 1782-1785).

7. ábra: Kijelölt turista útvonalak (saját szerkesztés). .46

8. ábra: Civil úthálózat javaslat (saját szerkesztés). . .48

9. ábra: A Budajenő és Páty közötti szekérút feltárása önálló használatú zöldútként..................................................50

10. ábra: Felszíni vizek a Békás-patak vízgyüjtő területén (saját szerkesztés)..........................................................52

11. ábra: A felhagyott vasútvonal Biatorbágy területén (saját szerkesztés)..........................................................55

12. ábra: Mezőgazdasági úthálózat a hagyományos településközi utak kiemelésével (saját szerkesztés)..... .57

13. ábra: A Budajenő és Páty közötti településközi összekötő út az első (1782-85) és a második (1829-1866) katonai felmérésen, valamint topográfiai térképen (2000).

14. ábra: A településközi út légifelvételen (2000), a felső szakasz tulajdonosi helyzetének bemutatásával (saját szerkesztés).

15. ábra: Saját zöldút-hálózat koncepció a Zsámbéki-medencére (saját szerkesztés). . .61

16. ábra: Mezőgazdasági úton kijelölt zöldút kiváltása vízparti zöldúttal 8saját szerkesztés).

17. ábra: Tervezett térségi kerékpárút zöldút alternatívája hagyományos településközi út mentén (saját szerkesztés)

18. ábra: Tervezett új fớt menti kerékpárút kiváltási lehetősége vízparti zöldúttal (saját szerkesztés)..................62

19. ábra: A "zöldút kialakítására javasolt térségi övezet" lehatárolása (saját szerkesztés).......................................65

20. ábra: Az 'ökológiai folyosó' és a 'zöldút kialakítására javasolt' térségi övezetek átfedése (saját szerkesztés)....66 21. ábra: Zöldutak alapvető kialakítási lehetőségei a rekreációs és az ökológiai szerepü tájelemekkel összefüggésben (saját szerkesztés). .69

22. ábra: Zöldúttípusok a Zsámbéki-medence példáján. .90

\section{Táblázatjegyzék}

1. táblázat: A zöldút és a vele rokon fogalmak jelentéstartalmai (saját szerkesztés, Kapovits, 2012)...... .79

2. táblázat: A zöldút-tervezési munkarészek beépítési lehetősége a területrendezési tervek előkészítő 
munkarészébe (saját szerkesztés).

3. táblázat: A zöldút-tervezési munkarészek beépítési lehetősége a területrendezési tervek javaslattevő munkarészeibe (saját szerkesztés)... .82

4. táblázat: Összefoglalás a zöldutak elhelyezkedés szerinti típusairól és azok feladatairól. .89 
